Supporting Information

\title{
Iminyl Radical-Triggered 1,5-Hydrogen Atom Transfer/Heck-Type Coupling by Visible-Light Photoredox Catalysis
}

Li Chen, Li-Na Guo, Zhi-Yong Ma, Yu-Rui Gu, Junjie Zhang and Xin-Hua Duan* Department of Chemistry, School of Science, Xi'an Key Laboratory of Sustainable Energy Material Chemistry, and MOE Key Laboratory for Nonequilibrium Synthesis and Modulation of Condensed Matter, Xi'an Jiaotong University, Xi'an 710049, China E-mail: duanxh@xjtu.edu.cn

\section{Table of Contents}

The Light Source and the Material of the Irradiation Vessel S2 $\begin{array}{ll}\text { Optimization of Oxime Esters 1a and Styrene 2a } & \text { S3 }\end{array}$ Investigation of the Reaction Mechanism $\quad$ S8 $\begin{array}{ll}\text { Reference } & \text { S15 }\end{array}$

${ }^{1} \mathrm{H}$ NMR and ${ }^{13} \mathrm{C}$ NMR Spectra of Products $3 \quad$ S16

${ }^{1} \mathrm{H}$ NMR and ${ }^{13} \mathrm{C}$ NMR Spectra of Products $4 \quad \mathbf{S 4 0}$

${ }^{1} \mathrm{H}$ NMR and ${ }^{13} \mathrm{C}$ NMR Spectra of Products 5a and 6a 


\section{The Light Source and the Material of the Irradiation Vessel}

Manufacturer: Xi 'an WATTECS experimental equipment co. LTD

Model: WP-VLH-1020

Broadband source: $\lambda=460-470 \mathrm{~nm}$

Spectral distribution and intensity:

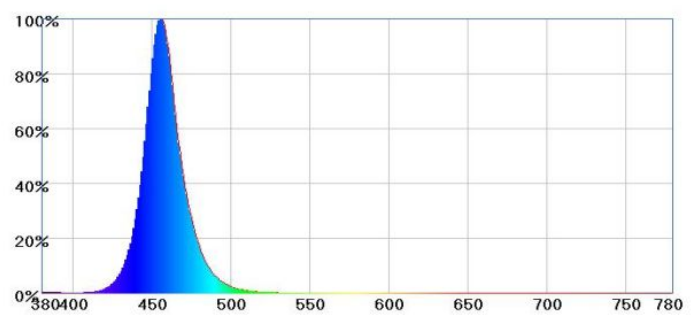

Material of the irradiation vessel: borosilicate reaction tube

Distance from the light source to the irradiation vessel: $2.0 \mathrm{~cm}$

Not use any filters
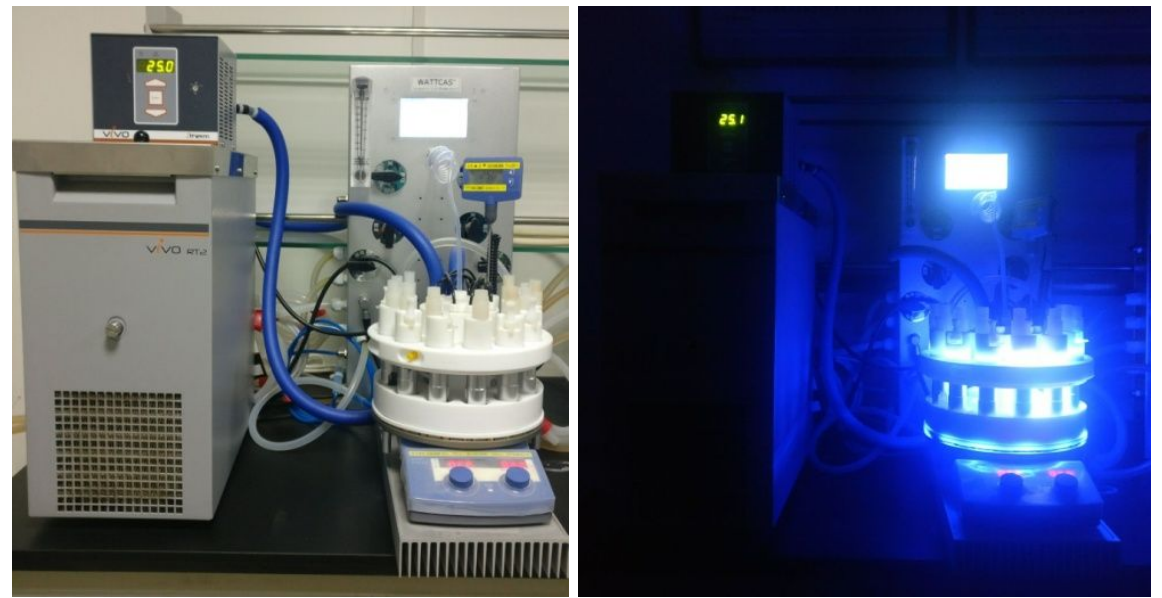

(photographed by author Li-Na Guo) 


\section{Optimization of Oxime Esters 1a and Styrene 2a}

Screening of solvents ${ }^{a}$<smiles>CC(=O)ON=C(C)CCC(C)C</smiles>

$1 \mathrm{a}$<smiles>C=Cc1ccccc1</smiles>

$2 a$

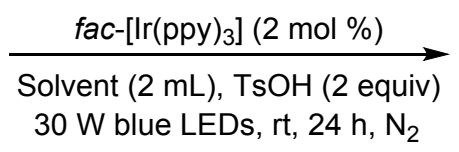

Solvent ( $2 \mathrm{~mL})$, TsOH (2 equiv) $30 \mathrm{~W}$ blue LEDs, rt, $24 \mathrm{~h}, \mathrm{~N}_{2}$

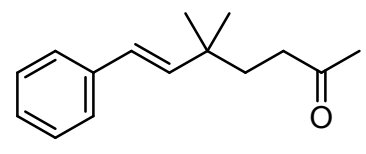

3a

\begin{tabular}{ccc}
\hline entry & solvent & yield $(\%)^{b}$ \\
\hline 1 & MeCN & 0 \\
2 & acetone & 0 \\
3 & DCE & 0 \\
4 & $\mathrm{PhCH}_{3}$ & 0 \\
5 & $\mathrm{THF}$ & 0 \\
6 & $1,4-$ dioxane & trace \\
7 & $\mathrm{DMF}$ & 25 \\
8 & $\mathrm{NMP}$ & 56 \\
9 & $\mathrm{DMAc}$ & 61 \\
10 & $\mathrm{DMSO}$ & 68 \\
11 & $\mathrm{CH} O \mathrm{OH}$ & 0 \\
12 & $\mathrm{HOAc}$ & 0 \\
\hline
\end{tabular}

${ }^{a}$ Reaction conditions: $2.0 \mathrm{~mol} \% \mathrm{fac}$-[ $\left.\operatorname{Ir}(\mathrm{ppy})_{3}\right], \mathbf{1 a}(0.2 \mathrm{mmol}, 1.0$ equiv), $\mathbf{2 a}(0.4 \mathrm{mmol}, 2.0$ equiv $)$ and $\mathrm{TsOH}(0.4 \mathrm{mmol}, 2.0$ equiv) in solvent $(2.0 \mathrm{~mL})$ were irradiated by $30 \mathrm{~W}$ blue light-emitting diodes (LEDs) for $24 \mathrm{~h}$ under $\mathrm{N}_{2} \cdot{ }^{b}$ Yields of isolated product. $\mathrm{HOAc}=$ acetic acid. $\mathrm{MeCN}=$ acetonitrile. $\mathrm{DMF}=N, N$-dimethylformamide. $\mathrm{DMAc}=$ dimethylacetamide. $\mathrm{NMP}=N$-methyl pyrrolidone. $\mathrm{DMSO}=$ dimethyl sulfoxide $. \mathrm{DCE}=$ dichloroethane. $\mathrm{THF}=$ tetrahydrofuran. 


\section{Screening of additives ${ }^{a}$}<smiles>CCOOC(C)=NC(C)CCC(C)C</smiles>

$1 \mathrm{a}$<smiles>C=Cc1ccccc1</smiles>

2a

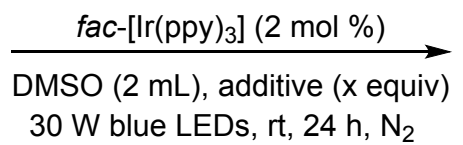

$30 \mathrm{~W}$ blue LEDs, rt, $24 \mathrm{~h}, \mathrm{~N}_{2}$

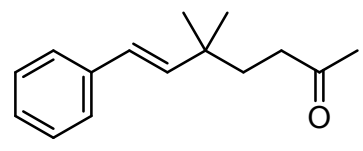

3a

\begin{tabular}{cccc}
\hline entry & additive & $\mathrm{x}$ & ${\text { yield }(\%)^{b}}^{b}$ \\
\hline 1 & $\mathrm{TsOH}$ & 1.0 & 61 \\
2 & $\mathrm{TfOH}$ & 1.0 & 52 \\
3 & $\mathrm{MSA}$ & 1.0 & 59 \\
4 & $\mathrm{HOAc}$ & 1.0 & 0 \\
5 & $\mathrm{TFA}$ & 1.0 & 56 \\
6 & $\mathrm{HCOOH}$ & 1.0 & 0 \\
7 & $\mathrm{Benzoic} \mathrm{acid}$ & 1.0 & 0 \\
8 & $\mathrm{Ph}\left(\mathrm{F}_{5}\right) \mathrm{COOH}$ & 1.0 & 0 \\
9 & $\mathrm{TsOH}$ & 0.5 & 25 \\
10 & $\mathrm{TsOH}$ & 1.5 & 48 \\
11 & $\mathrm{TsOH}$ & 2.0 & 68 \\
12 & $\mathrm{TsOH}_{5}$ & 2.5 & 45 \\
13 & $\mathrm{~K}_{2} \mathrm{CO}$ & 2.0 & 0 \\
14 & $\mathrm{Cs}_{2} \mathrm{CO}$ & 2.0 & 0 \\
15 & $\mathrm{NaOAc}_{3}$ & 2.0 & 0 \\
16 & ${ }^{t} \mathrm{BuOK}$ & 2.0 & 0 \\
17 & $\mathrm{Et}_{3} \mathrm{~N}$ & 2.0 & 0 \\
18 & $\mathrm{KH}_{2} \mathrm{PO}_{4}$ & 2.0 & 0 \\
19 & - & - & 0 \\
\hline
\end{tabular}

${ }^{a}$ Reaction conditions: $2.0 \mathrm{~mol} \% \mathrm{fac}$-[Ir(ppy $\left.)_{3}\right], \mathbf{1 a}(0.2 \mathrm{mmol}, 1.0$ equiv), $\mathbf{2 a}(0.4 \mathrm{mmol}, 2.0$ equiv $)$ and additive (x equiv) in DMSO $(2.0 \mathrm{~mL})$ were irradiated by $30 \mathrm{~W}$ blue light-emitting diodes (LEDs) for $24 \mathrm{~h}$ under $\mathrm{N}_{2} .{ }^{b}$ Yields of isolated product. TsOH $=4$-Methylbenzenesulfonic acid. $\mathrm{TfOH}=$ Trifluoromethanesulfonic acid. MSA $=$ Methanesulfonic acid. TFA $=$ Trifluoroacetic acid. 


\section{Screening of photocatalysts ${ }^{a}$}<smiles>CC(=O)ON=C(C)CCC(C)C</smiles>

$1 \mathbf{a}$<smiles>C=Cc1ccccc1</smiles>

$2 a$

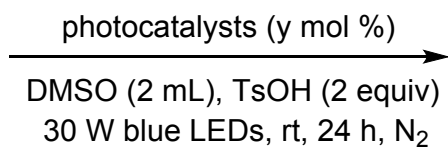

$30 \mathrm{~W}$ blue LEDs, rt, $24 \mathrm{~h}, \mathrm{~N}_{2}$

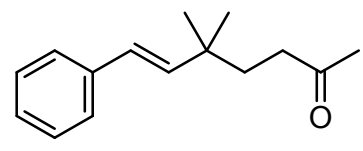

$3 a$

\begin{tabular}{|c|c|c|}
\hline entry & photocatalysts (y mol \%) & yield $(\%)^{b}$ \\
\hline 1 & $f a c-\left[\operatorname{Ir}(\mathrm{ppy})_{3}\right](1 \mathrm{~mol} \%)$ & 73 \\
\hline 2 & $f a c-\left[\operatorname{Ir}(\mathrm{ppy})_{3}\right](2 \mathrm{~mol} \%)$ & 68 \\
\hline 3 & $f a c-\left[\operatorname{Ir}(\mathrm{ppy})_{3}\right](0.5 \mathrm{~mol} \%)$ & $<20$ \\
\hline 4 & {$\left[\operatorname{Ir}(\mathrm{ppy})_{2}(\mathrm{dtbbpy})\right]\left(\mathrm{PF}_{6}\right)(2 \mathrm{~mol} \%)$} & 0 \\
\hline 5 & {$\left[\operatorname{Ir}\left(\mathrm{dF}\left(\mathrm{CF}_{3}\right) \mathrm{ppy}\right)_{2}(\mathrm{dtbpy})\right]\left(\mathrm{PF}_{6}\right)(2 \mathrm{~mol} \%)$} & 0 \\
\hline 6 & {$\left[\mathrm{Ru}(\mathrm{bpy})_{3}\right] \mathrm{Cl}_{2}(2 \mathrm{~mol} \%)$} & 0 \\
\hline 7 & {$\left[\mathrm{Ru}(\mathrm{bpy})_{3}\right]\left(\mathrm{PF}_{6}\right)_{2}(2 \mathrm{~mol} \%)$} & 0 \\
\hline 8 & $\mathrm{Cu}(\mathrm{dap})_{2} \mathrm{Cl}(2 \mathrm{~mol} \%)$ & 0 \\
\hline 9 & Eosin Y (2 mol \%) & 0 \\
\hline 10 & Rhodamine B (2 mol \%) & 0 \\
\hline 11 & Methylene blue ( $2 \mathrm{~mol} \%$ ) & 0 \\
\hline 12 & Fluorescein (2 mol \%) & 0 \\
\hline 13 & Phenothiazine ( $2 \mathrm{~mol} \%$ ) & 0 \\
\hline 14 & 10-Methylphenothiazine (2 mol \%) & 0 \\
\hline 15 & 4CzIPN (2 mol \%) & 0 \\
\hline $16^{c}$ & - & 0 \\
\hline
\end{tabular}

${ }^{a}$ Reaction conditions: y mol \% photocatalysts, 1 a $(0.2 \mathrm{mmol}, 1.0$ equiv), 2 a ( $0.4 \mathrm{mmol}, 2.0$ equiv $)$ and TsOH $(0.4 \mathrm{mmol}, 2.0$ equiv) in DMSO $(2.0 \mathrm{~mL})$ were irradiated by $30 \mathrm{~W}$ blue light-emitting diodes (LEDs) for $24 \mathrm{~h}$ under $\mathrm{N}_{2} .{ }^{b}$ Yields of isolated product. ${ }^{c}$ The reaction was conducted in the absence of visible light or photocatalyst. 

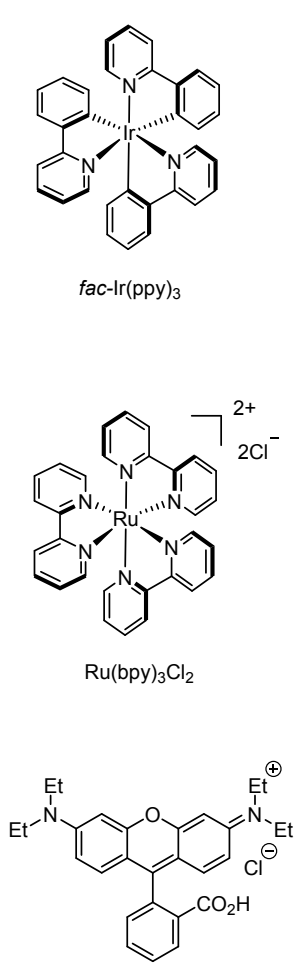

Rhodamine B

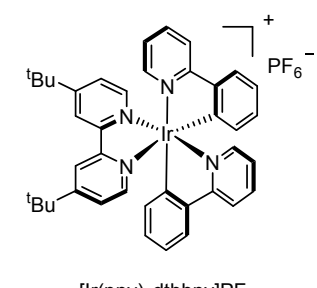

[Ir(ppy $)_{2}$ dtbbpy]PF 6

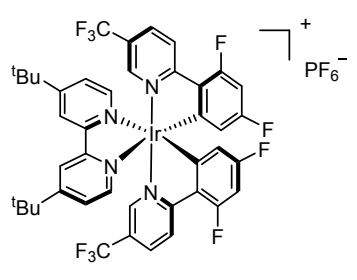

$\left[\operatorname{Ir}\left(\mathrm{dF}\left(\mathrm{CF}_{3}\right) \mathrm{ppy}\right)_{2}(\mathrm{dtbbpy})\right]\left(\mathrm{PF}_{6}\right)$
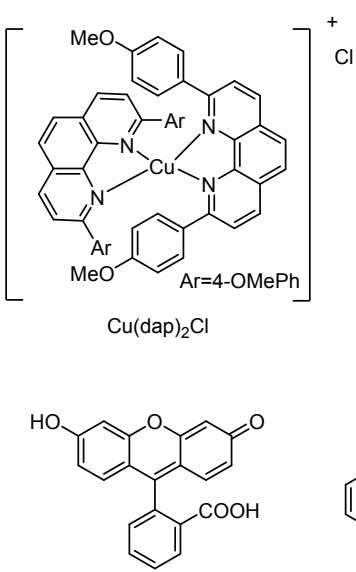

Fluorescein

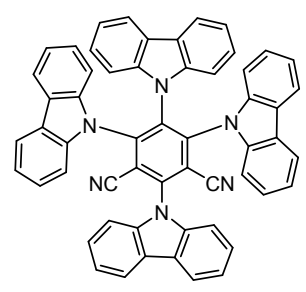

4CZIPN

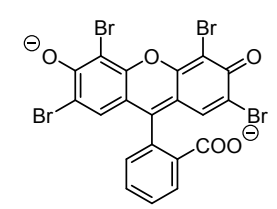

Eosin $Y$

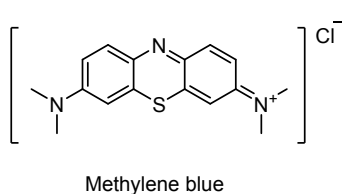

Methylene blue (n)
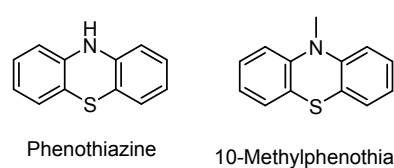

10-Methylphenothiazine 
Screening of acyl oxime substrates ${ }^{a}$

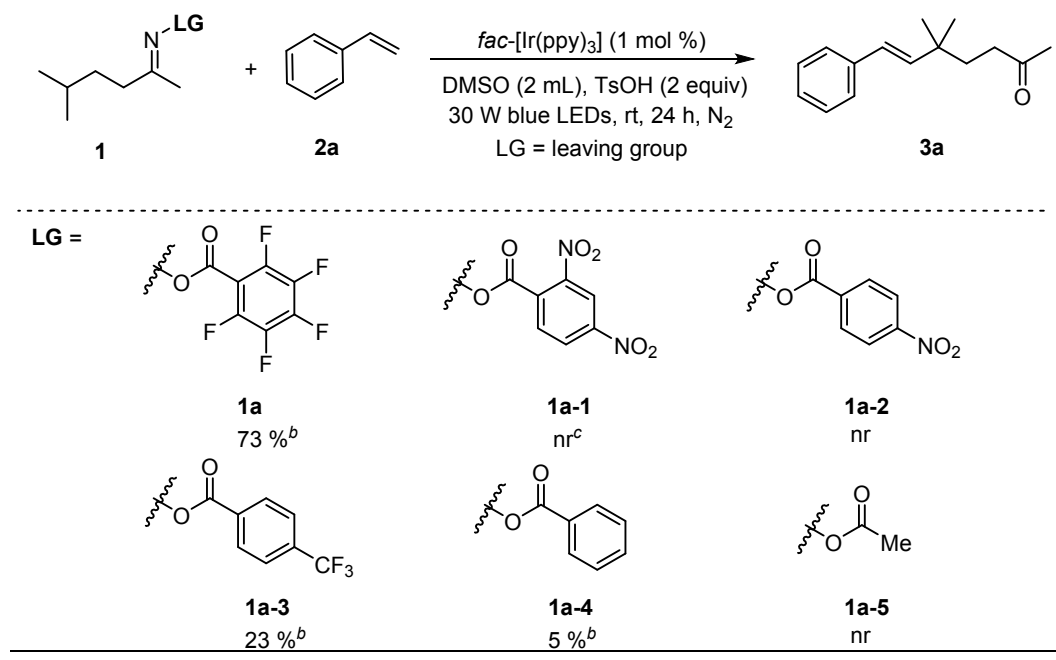

${ }^{a}$ Reaction conditions: $1.0 \mathrm{~mol} \% \mathrm{fac}$-[Ir(ppy $\left.)_{3}\right], \mathbf{1}(0.2 \mathrm{mmol}, 1.0$ equiv), $2 \mathrm{a}(0.4 \mathrm{mmol}, 2.0$ equiv), and TsOH (0.4 mmol, 2.0 equiv) in DMSO $(2.0 \mathrm{~mL})$ were irradiated by $30 \mathrm{~W}$ blue light-emitting diodes (LEDs) for $24 \mathrm{~h}$ under $\mathrm{N}_{2} .{ }^{b}$ Yields of isolated product. ${ }^{c} \mathrm{nr}=$ No reaction. 


\section{Investigation of the Reaction Mechanism}

\section{Radical Inhibiting Experiments}

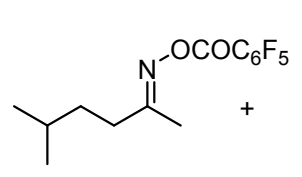

$1 a$<smiles>C=Cc1ccccc1</smiles>

$2 a$ $\underset{\text { standard conditions }}{\stackrel{\text { TEMPO }}{\longrightarrow}}$

TEMP<smiles>CC(=O)CCC(C)(C)/C=C/c1ccccc1</smiles>

$3 a$

$34 \%$

$20 \%$

$0 \%$<smiles>CC(=O)CCC(C)(C)ON1C(C)(C)CCCC1(C)C</smiles>

$5 a$

$28 \%$

The addition of TEMPO obviously suppressed the reaction of $\mathbf{1 a}$ with $\mathbf{2 a}$ under the standard conditions. When 3.0 equiv of TEMPO was added, the yield of product 3a was reduced to $0 \%$ and the corresponding TEMPO-adduct 5a was isolated in $28 \%$ yield. This result indicates that a radical intermediate might be involved in this transformation.

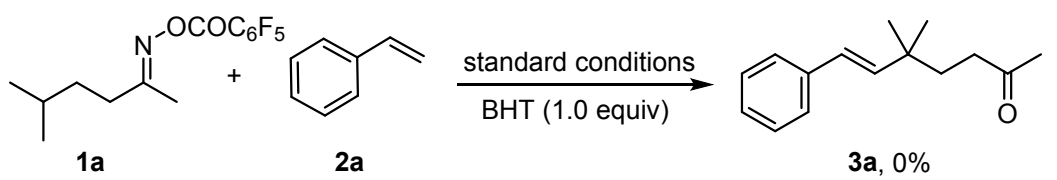

When 1.0 equiv of BHT was added to the reaction of $1 \mathbf{a}$ with $\mathbf{2 a}$ under the standard conditions, no desired product 3a was observed. This result indicates that a radical intermediate might be involved in this transformation. 


\section{Radical Clock Experiment}

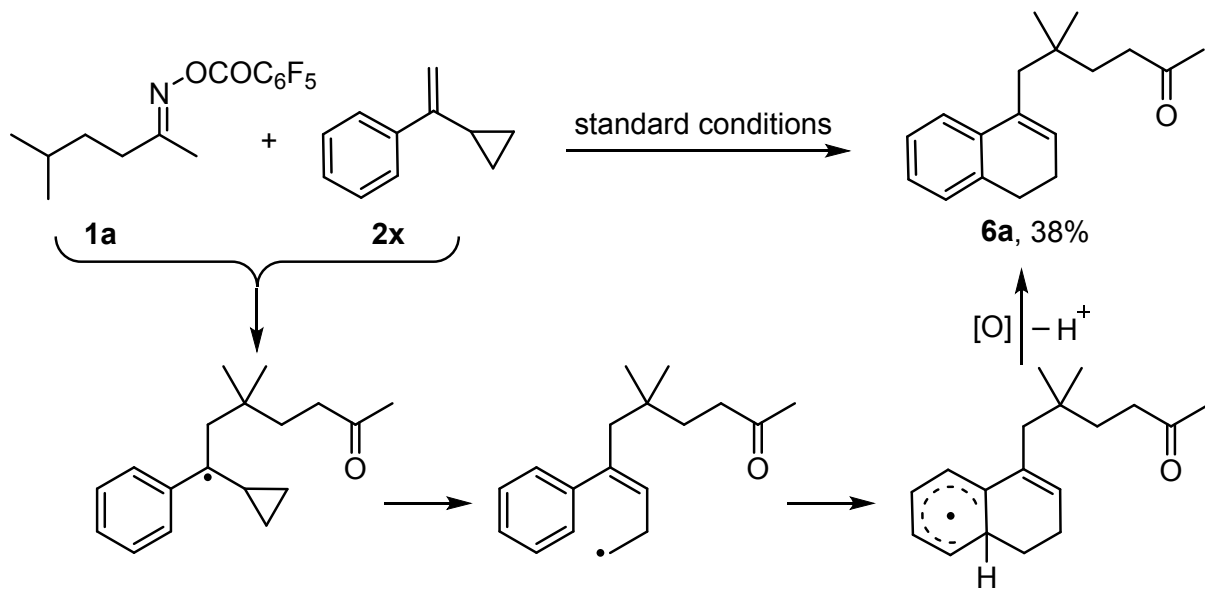

Treatment of 1a with $\mathbf{2 x}$ under the standard conditions delivered the ring-expanded product $\mathbf{6 a}$ in $38 \%$ isolated yield, which provides further evidence for a radical pathway. 


\section{Determination of the light intensity at $468 \mathrm{~nm}$}

The photon flux of the spectrophotometer was measured by ferrioxalate actinometry. The preparation of $0.15 \mathrm{M}$ solution of ferrioxalate and buffered solution of phenanthroline was according to the literature procedures. ${ }^{1}$ The fraction of light absorbed (f) by ferrioxalate solution was calculated using eq 1, where $A$ is the measured absorbance at $468 \mathrm{~nm}$ (Figure S1, $\mathrm{A}=0.411528$ ). Where $\mathrm{V}$ is the total volume $(0.00235 \mathrm{~L})$ of the solution after addition of phenanthroline. $\Delta \mathrm{A}$ is the difference in absorbance at $510 \mathrm{~nm}$ between the irradiated and non-irradiated solutions. 1 is the path length $(1.00 \mathrm{~cm})$, and $\varepsilon$ is the molar absorptivity at $510 \mathrm{~nm}$ $\left(11,100 \mathrm{~L} \mathrm{~mol}^{-1} \mathrm{~cm}^{-1}\right)$. Where $\Phi$ is the quantum yield for the ferrioxalate actinometer ( 0.92 for a $0.15 \mathrm{M}$ solution at $\lambda=468 \mathrm{~nm}) .^{2}$ At $468 \mathrm{~nm}$, photo flux was calculated to be $2.19 \times 10^{-9}$ einstein $\mathrm{s}^{-1}$.

$$
\begin{aligned}
\mathrm{f} & =1-10^{-\mathrm{A}} \\
\mathrm{mol} \mathrm{Fe} & =\frac{\mathrm{V} \times \Delta \mathrm{A}}{\mathrm{l} \times \varepsilon} \\
\text { photo flux } & =\frac{\mathrm{mol} \mathrm{Fe}^{2+}}{\Phi \times \mathrm{t} \times \mathrm{f}}
\end{aligned}
$$

Sample calculation:

$$
\begin{aligned}
\mathrm{f} & =1-10^{-0.411528} \\
& =0.61232 \\
\mathrm{~mol} \mathrm{Fe}^{2+} & =\frac{0.00235 \mathrm{~L}^{-1} \times 0.522229}{1.000 \mathrm{~cm} \times 11100 \mathrm{~L} \mathrm{~mol}^{-1} \mathrm{~cm}^{-1}} \\
& =1.11 \times 10^{-7} \mathrm{~mol} \\
\text { photo flux } & =\frac{1.11 \times 10^{-7}}{0.92 \times 90 \times 0.61232} \\
& =2.19 \times 10^{-9} \text { einstein s}^{-1}
\end{aligned}
$$




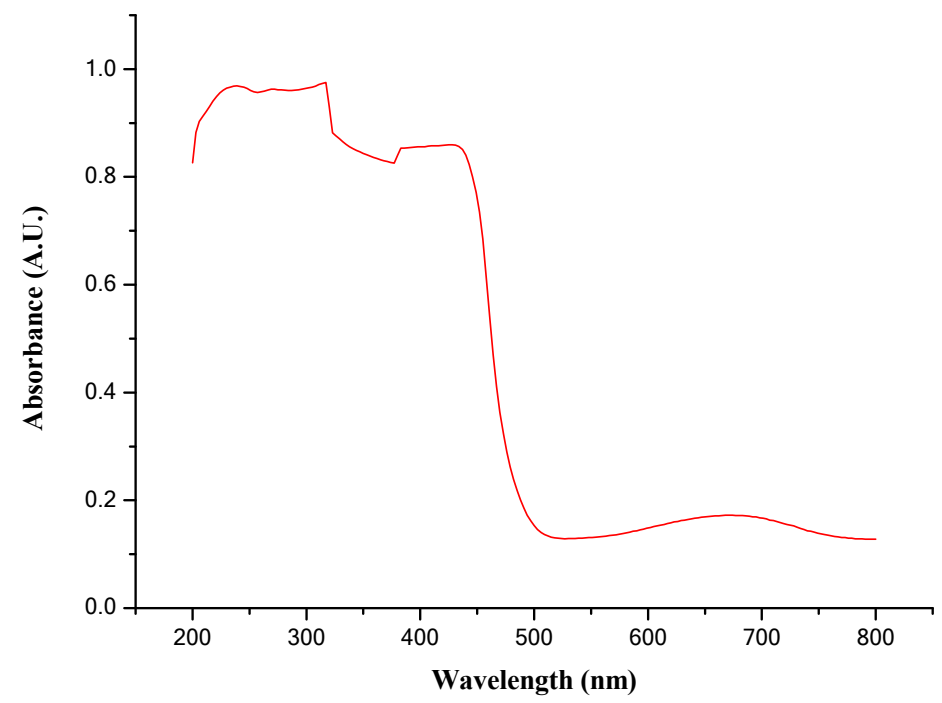

Figure S1. Absorbance of the ferrioxalate actinometer solution. 


\section{Determination of quantum yield:}<smiles>C=Cc1ccccc1</smiles>

$1 \mathrm{a}$

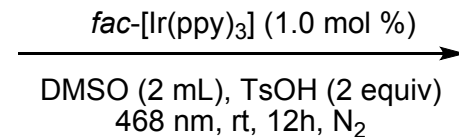
$468 \mathrm{~nm}, \mathrm{rt}, 12 \mathrm{~h}, \mathrm{~N}_{2}$

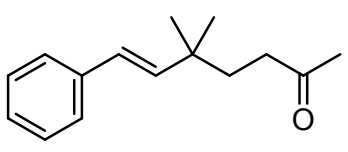

$3 a$

A cuvette was pumped into the glovebox. The cuvette was charged with (E)-5-methylhexan-2-one $O$-perfluorobenzoyl oxime 1a $(0.2 \mathrm{mmol}, 1.0$ equiv), fac-[Ir(ppy) $\left.)_{3}\right](0.002 \mathrm{mmol}, 1 \mathrm{~mol} \%)$, TsOH (0.4 mmol, 2.0 equiv), styrene $2 \mathrm{a}(0.4$ mmol, 2.0 equiv) and $2.0 \mathrm{~mL}$ of DMSO. The cuvette sealed with a cap and septa, then stirred and irradiated $(\lambda=468 \mathrm{~nm}$, slit width $=10.0 \mathrm{~nm})$ for $43200 \mathrm{~s}(12 \mathrm{~h})$. After irradiation, purification of the crude product by flash chromatography on silica gel (petroleum ether/ethyl acetate 20:1), $8.7 \mathrm{mg}$ of the $\mathbf{3 a}(20 \%)$ was isolated.

By UV-Vis, all incident light is absorbed by the $f a c-\left[\operatorname{Ir}(p p y)_{3}\right]$ photocatalyst under the reaction conditions (Figure S2, Absorbance $=0.612400$ ). Therefore, fraction of light absorbed is 0.75588 .

$$
\begin{aligned}
\text { Quantum Yield } & =\frac{\text { numbers of moles of product }}{\text { flux } \times \mathrm{f} \times \mathrm{t}} \\
& =\frac{8.7 / 216 / 1000}{2.19 \times 10^{-9} \times 0.75588 \times 43200} \\
& =0.56
\end{aligned}
$$

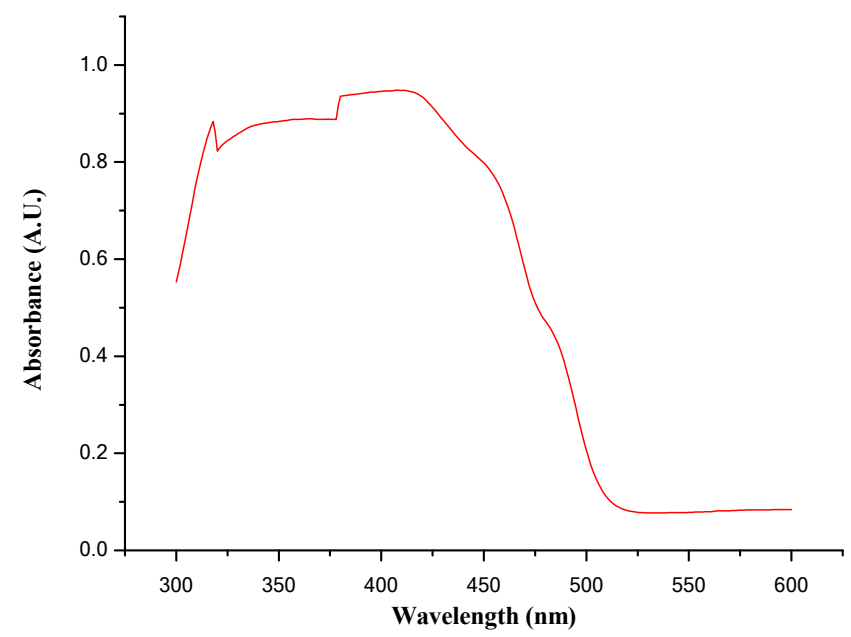

Figure S2. Absorbance of the $f a c$ - $\left[\operatorname{Ir}(\mathrm{ppy})_{3}\right]$ photocatalyst under the reaction conditions 


\section{Scale up reaction}

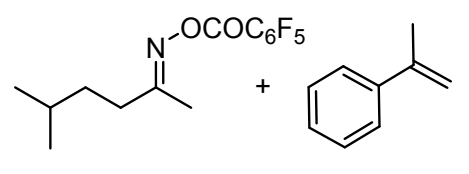

1a, $1.0 \mathrm{mmol}$

2o, $2.0 \mathrm{mmol}$

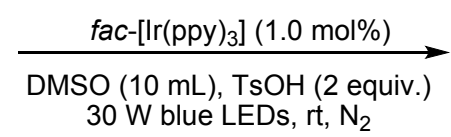

$30 \mathrm{~W}$ blue LEDs, rt, $\mathrm{N}_{2}$

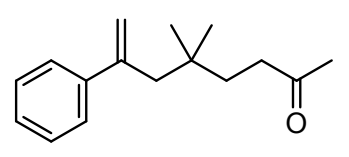

3o, $62 \%$

A $50 \mathrm{~mL}$ round bottom flask was equipped with a rubber septum and magnetic stir bar and was charged with 1a (1.0 mmol, 1.0 equiv.), 20 (2.0 mmol, 2.0 equiv.), fac-Ir(ppy)3 (0.01 mmol, $1 \mathrm{~mol} \%)$, TsOH (2.0 mmol, 2.0 equiv.). The flask was evacuated and backfilled with $\mathrm{N}_{2}$ for 3 times. DMSO $(10.0 \mathrm{~mL}, 0.1 \mathrm{M})$ was then added with syringe under $\mathrm{N}_{2}$. The mixture was then irradiated by a $30 \mathrm{~W}$ blue LEDs strips. After the reaction was complete (as judged by TLC analysis), then $10.0 \mathrm{~mL} \mathrm{H}_{2} \mathrm{O}$ was added and the mixture was stirred for 30 minutes at room temperature. The mixture was extracted with ethyl acetate $(3 \times 20 \mathrm{~mL})$. The combined organic extracts were washed with brine $(20 \mathrm{~mL})$, dried over $\mathrm{Na}_{2} \mathrm{SO}_{4}$ and concentrated in vacuo. Purification of the crude product by flash chromatography on silica gel (petroleum ether/ethyl acetate $30: 1$ to $20: 1)$ to give the corresponding products in $62 \%(142.8 \mathrm{mg})$ yield. 


\section{Control experiment (using monohydrated PTSA and anhydrous PTSA)}<smiles>CC(=O)ON=C(C)CCC(C)C</smiles>

1a<smiles>CC(=O)ON=C(C)CCC(C)C</smiles>

1a<smiles>C=Cc1ccccc1</smiles>

$2 a$

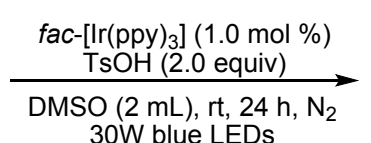

$30 \mathrm{~W}$ blue LEDs<smiles>CC(=O)CCC(C)(C)/C=C/c1ccccc1</smiles>

3a, $73 \%$<smiles>CC(=O)CCC(C)(C)CC(O)c1ccccc1</smiles><smiles>C=Cc1ccccc1</smiles>

$2 \mathrm{a}$

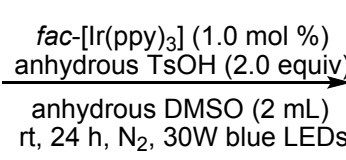<smiles>CC(=O)CCC(C)(C)/C=C/c1ccccc1</smiles>

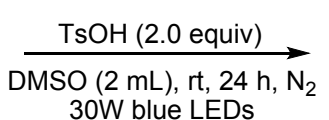<smiles>CC(=O)CCC(C)(C)/C=C/c1ccccc1</smiles>

When 2.0 equiv of anhydrous $\mathrm{TsOH}$ was used instead of monohydrated $\mathrm{TsOH}$ for the reaction of $1 \mathbf{a}$ and $\mathbf{2 a}$, the desired product $\mathbf{3 a}$ was observed in $32 \%$ yield. This result indicates that the crystalline water of $\mathrm{TsOH}$ had significant effect on the reaction and it might involve in reaction, serving as hydroxyl source to give corresponding alcohol.

Furthermore, treatment of $\gamma$-hydroxyalkylation of alkyl ketone (corresponding alcohol as described in ref $7 \mathrm{j}$ ) under the standard conditions delivered the 3a in $91 \%$ isolated yield, which indicates that $\gamma$-hydroxyalkylation of alkyl ketone might also be intermediate in this transformation. 


\section{Reference}

(1) Cismesia, M. A.; Yoon, T. P. Characterizing Chain Processes in Visible Light Photoredox Catalysis. Chem. Sci. 2015, 6, 5426-5434.

(2) Hatchard, C. G.; Parker, C. A. A New Sensitive Chemical Actinometer II. Potassium Ferrioxalate as a Standard Chemical Actinometer. Proc. R. Soc. 1956, 235, 518-536. 


\section{${ }^{1} \mathrm{H}$ NMR and ${ }^{13} \mathrm{C}\left\{{ }^{1} \mathrm{H}\right\}$ NMR Spectra of Products 3}

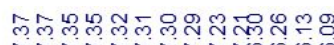

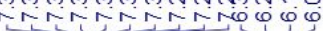

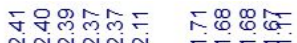

管

3a

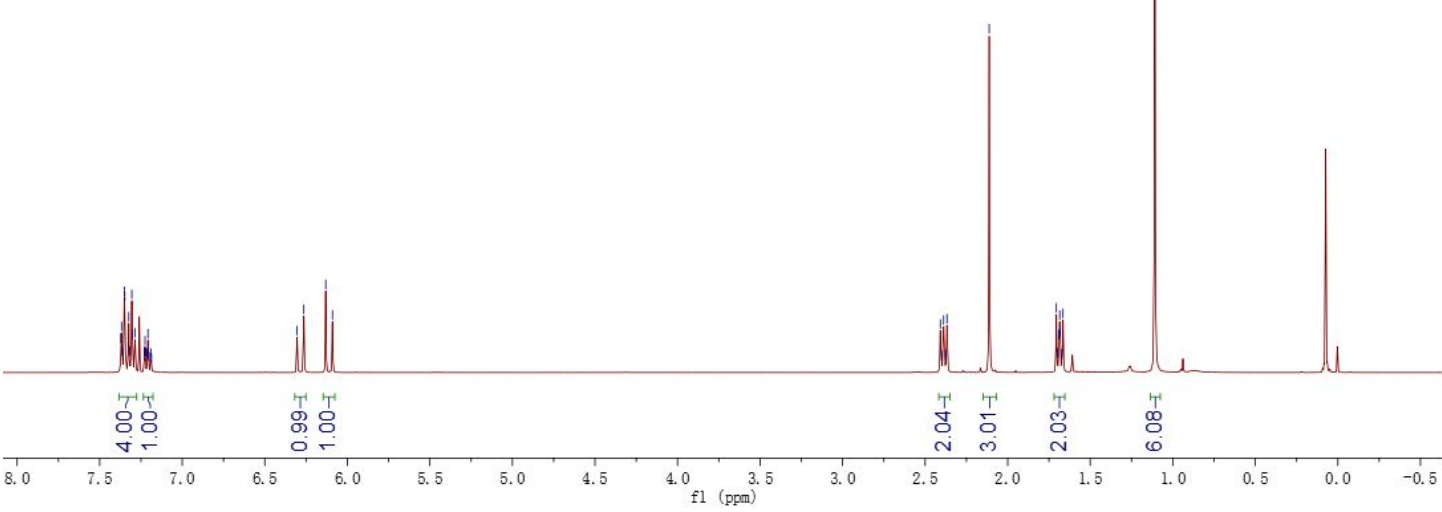

₹<smiles>CC(=O)CCC(C)(C)/C=C/c1ccccc1</smiles>

3a
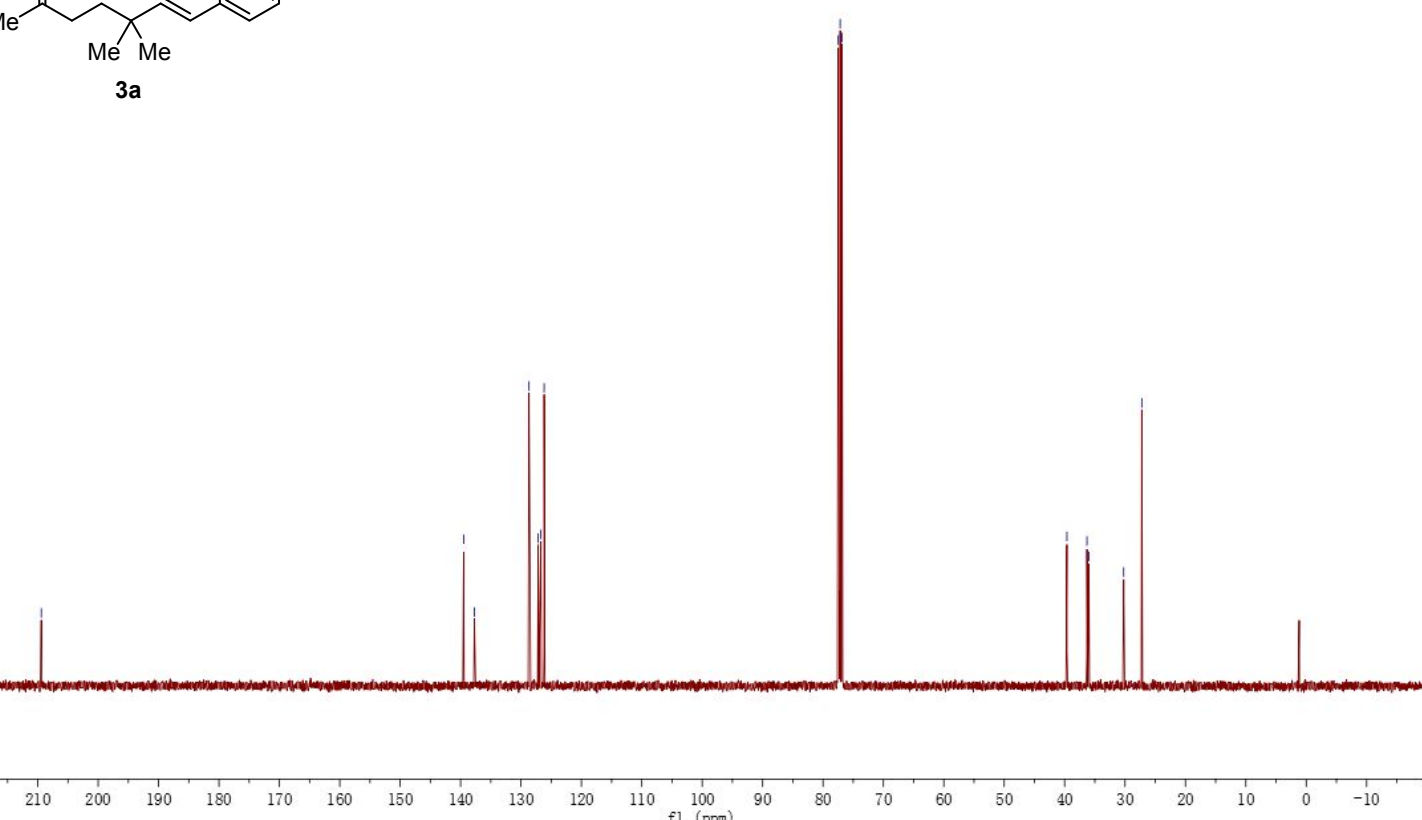


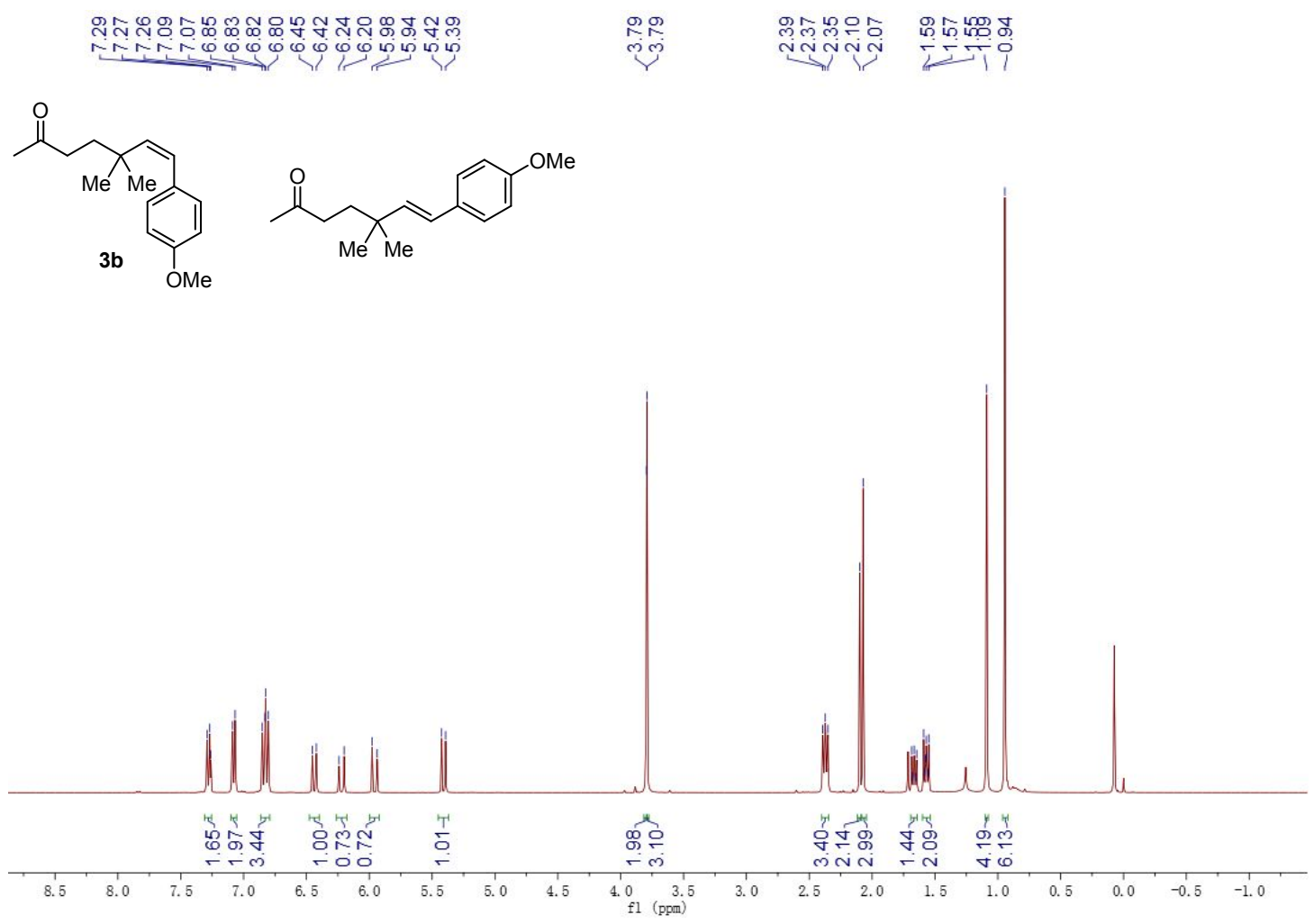

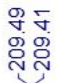

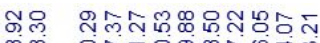

舟

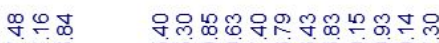

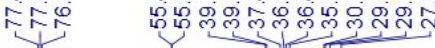

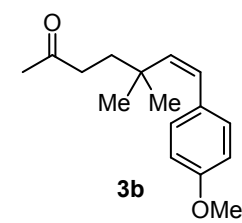<smiles>COc1ccc(/C=C/C(C)(C)CCC(C)=O)cc1</smiles>
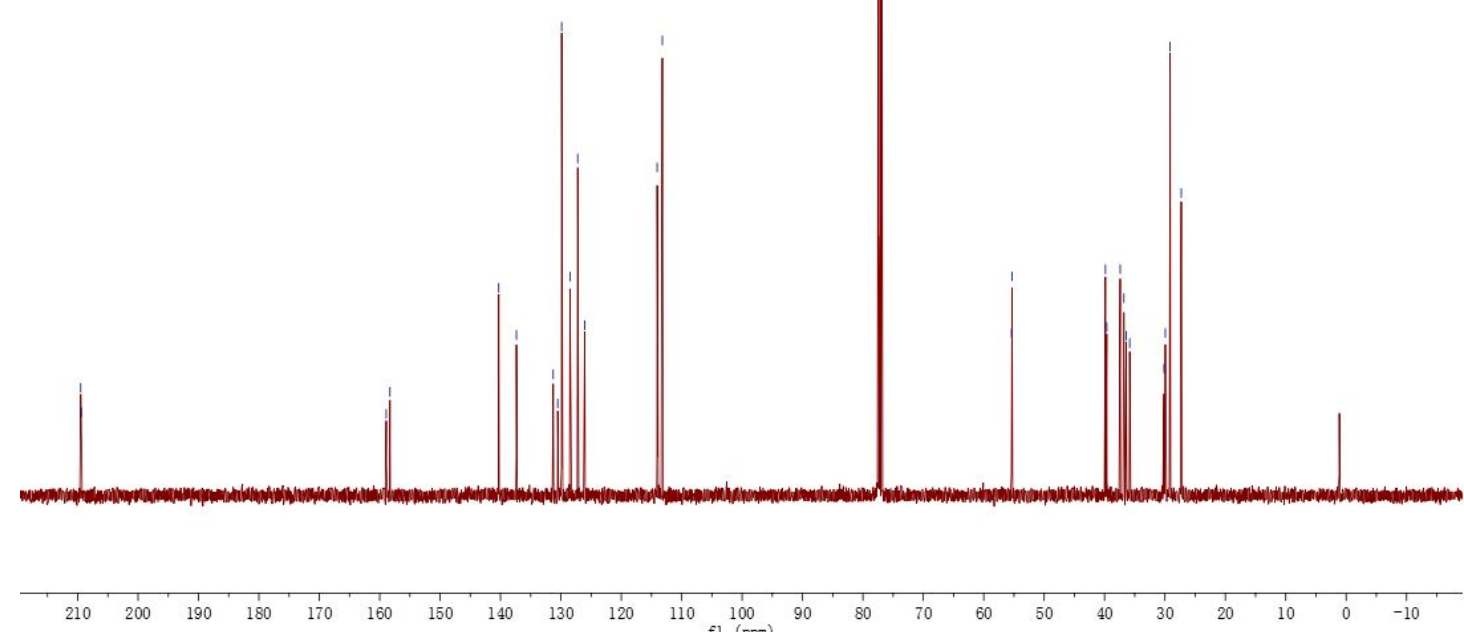


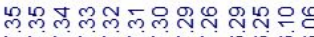

rñañún

テ

$\underbrace{M e}_{M e}$

$3 c$
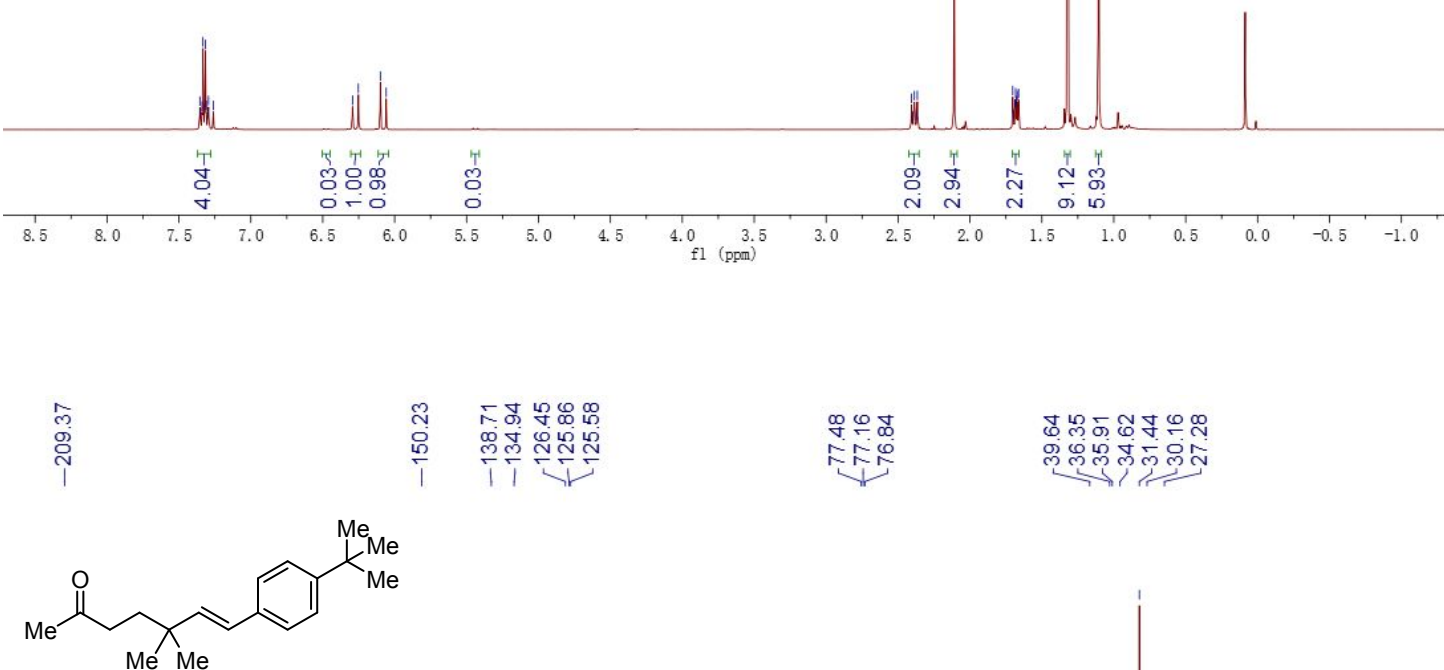

$3 c$

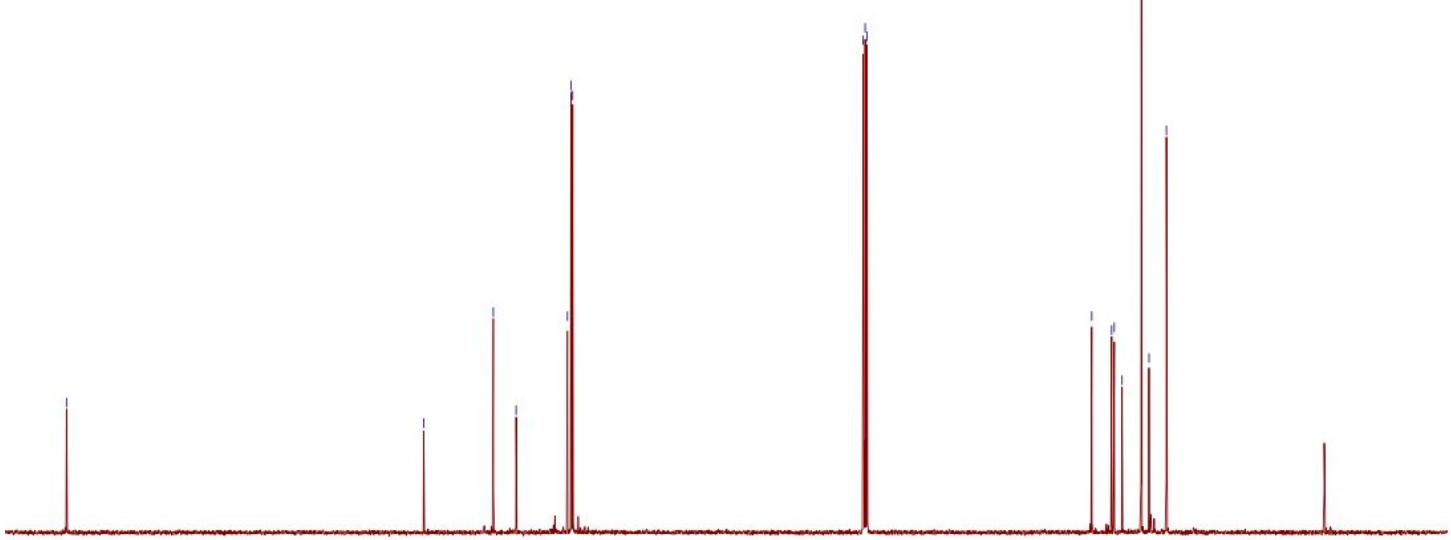

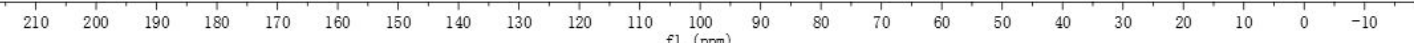




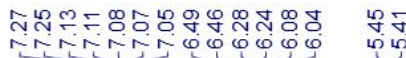

MNNTNE 00000

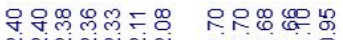

$\underbrace{M e}_{M e}$

3d
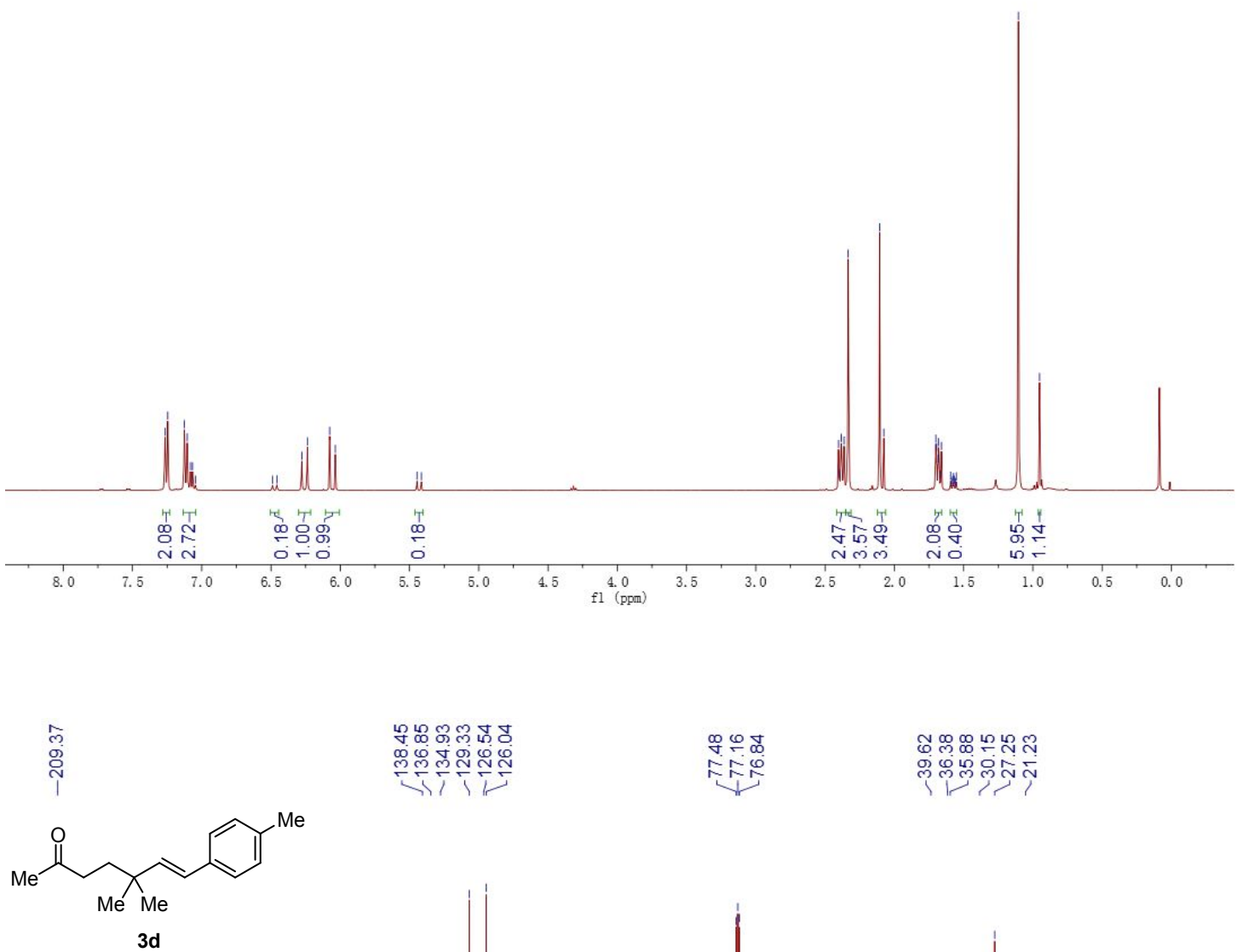

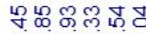

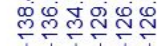

$\stackrel{5}{\infty}$

ฮึ

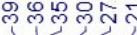

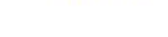

춘
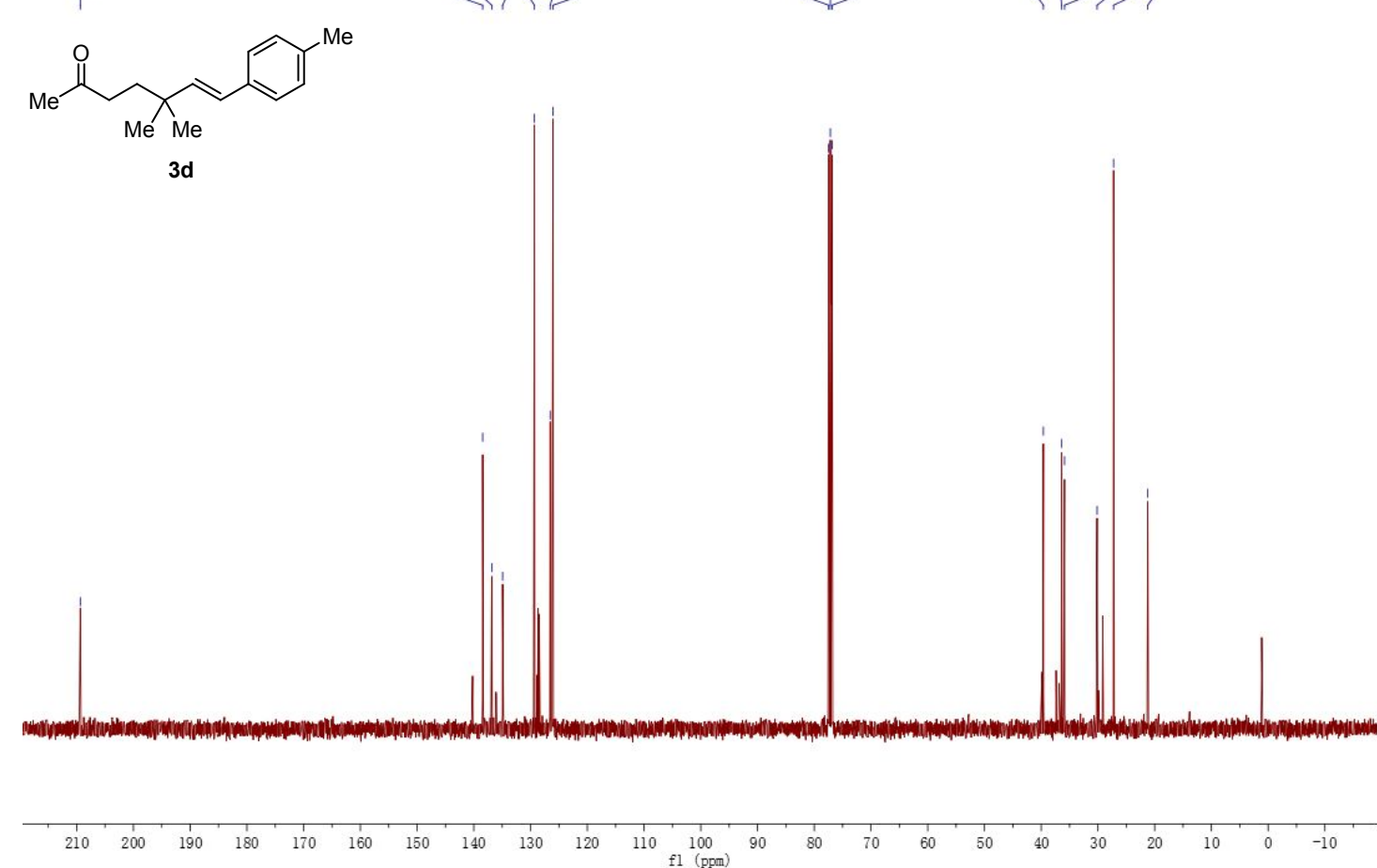


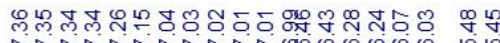

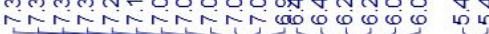

$\underbrace{M e}_{M e}$

$3 e$

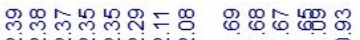
nnnniñ
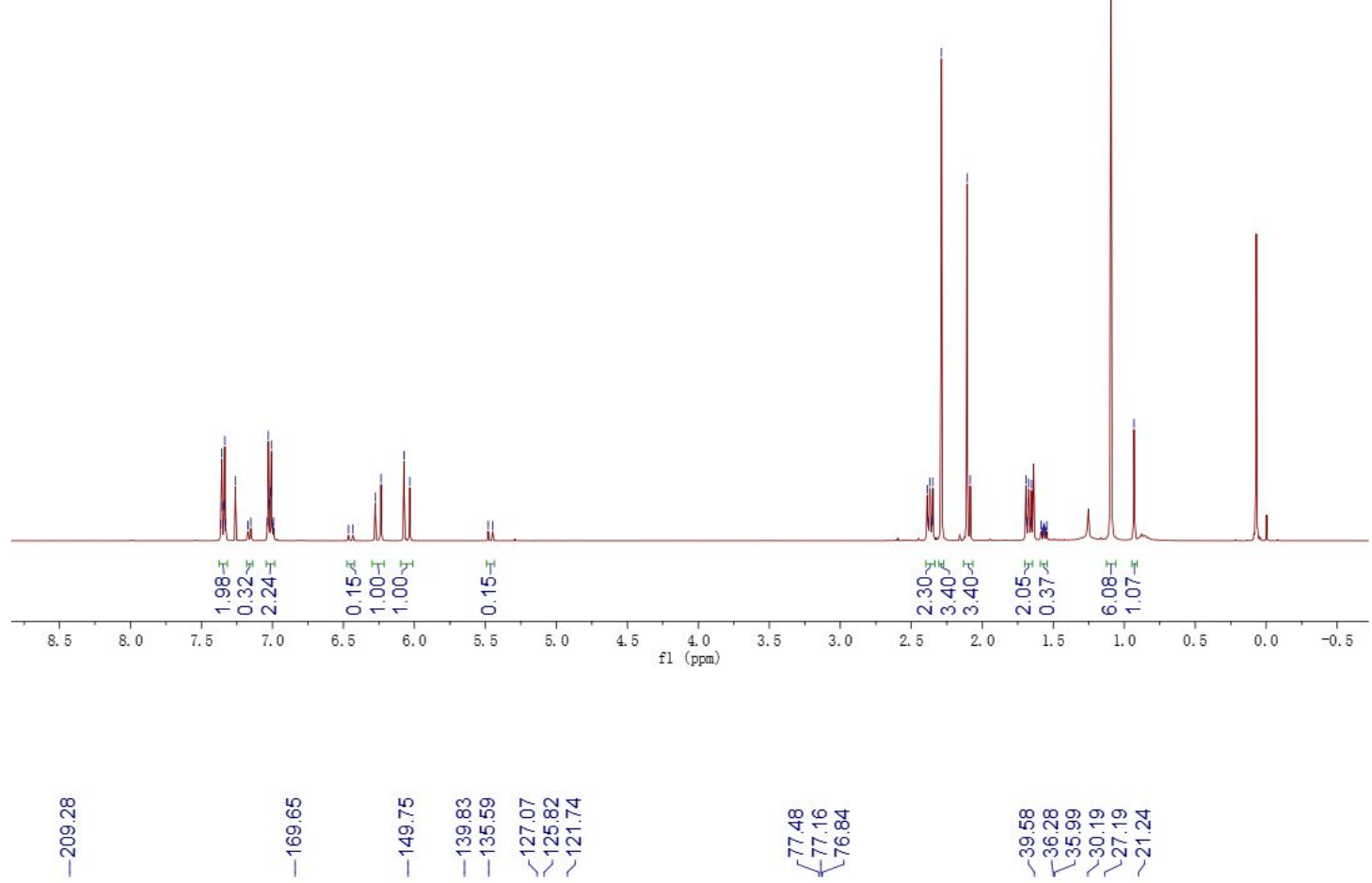

$\underbrace{M e}_{M e}$

$3 e$
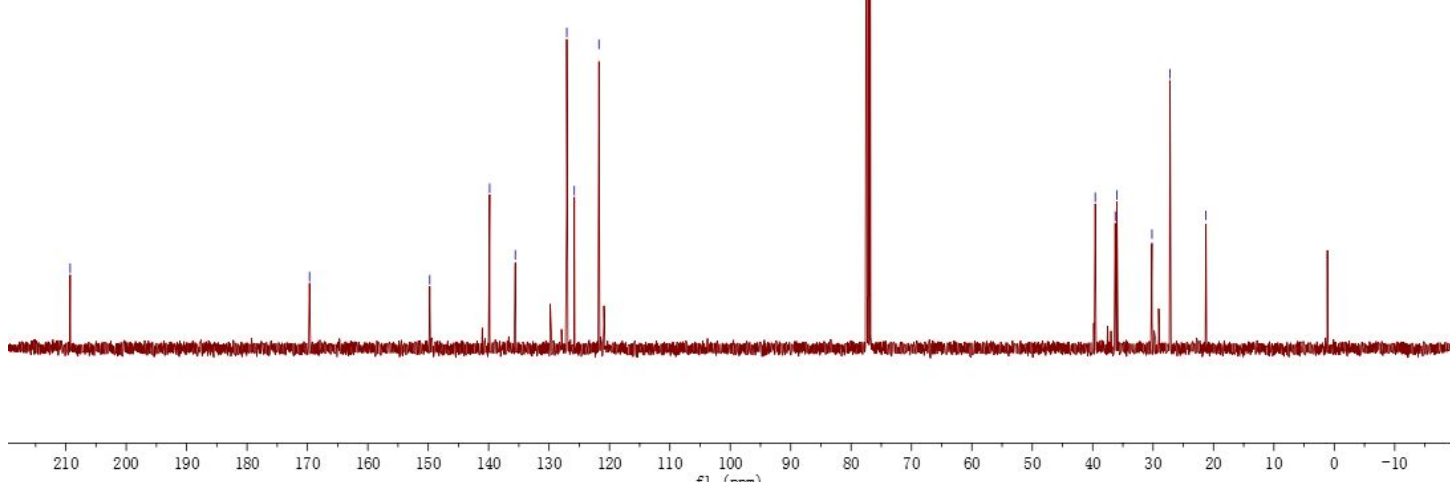

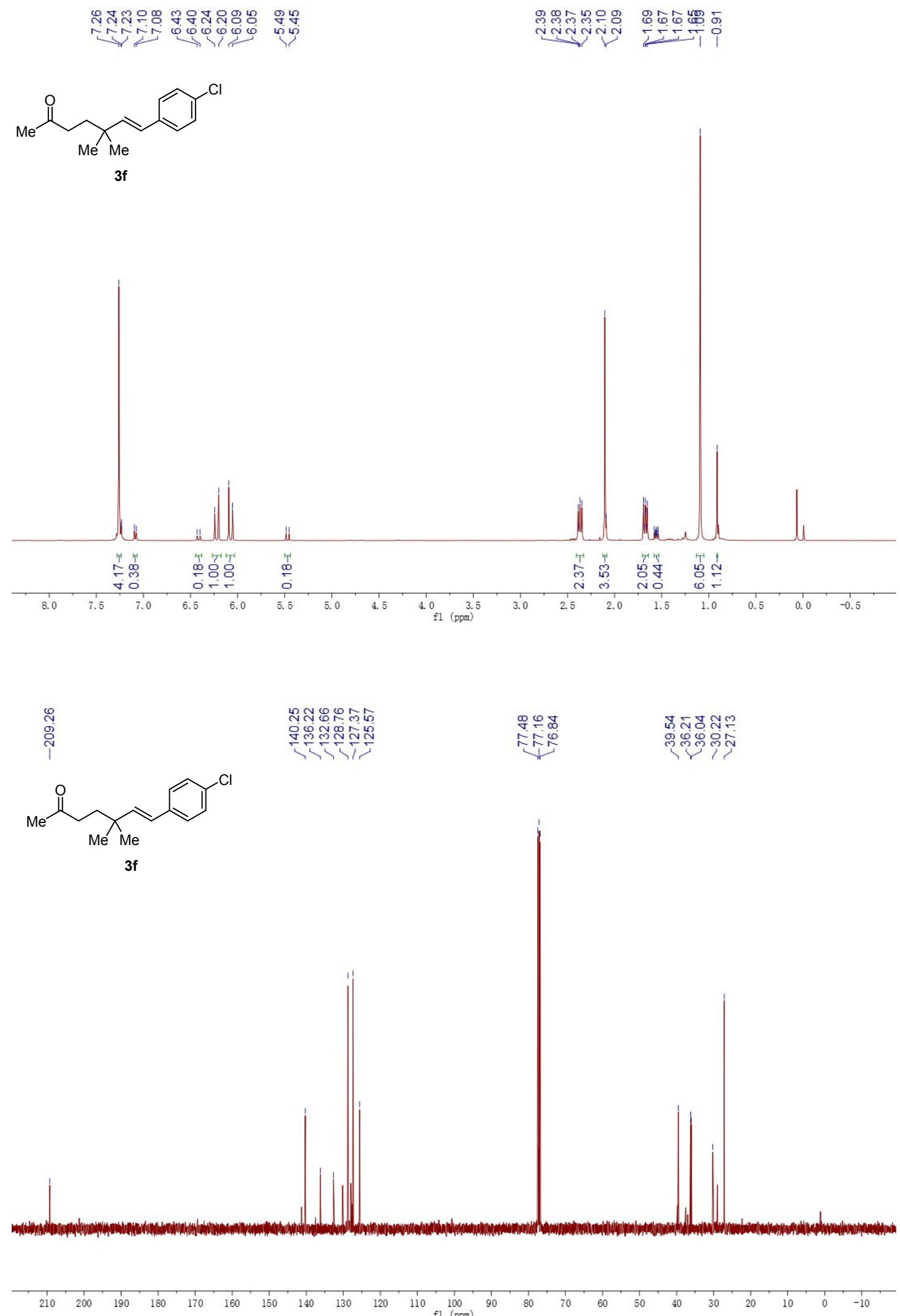


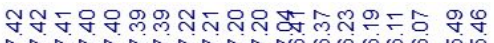

rrind

$\underbrace{M e}_{M e}$

$3 g$

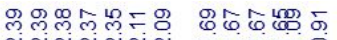

NnNnNan

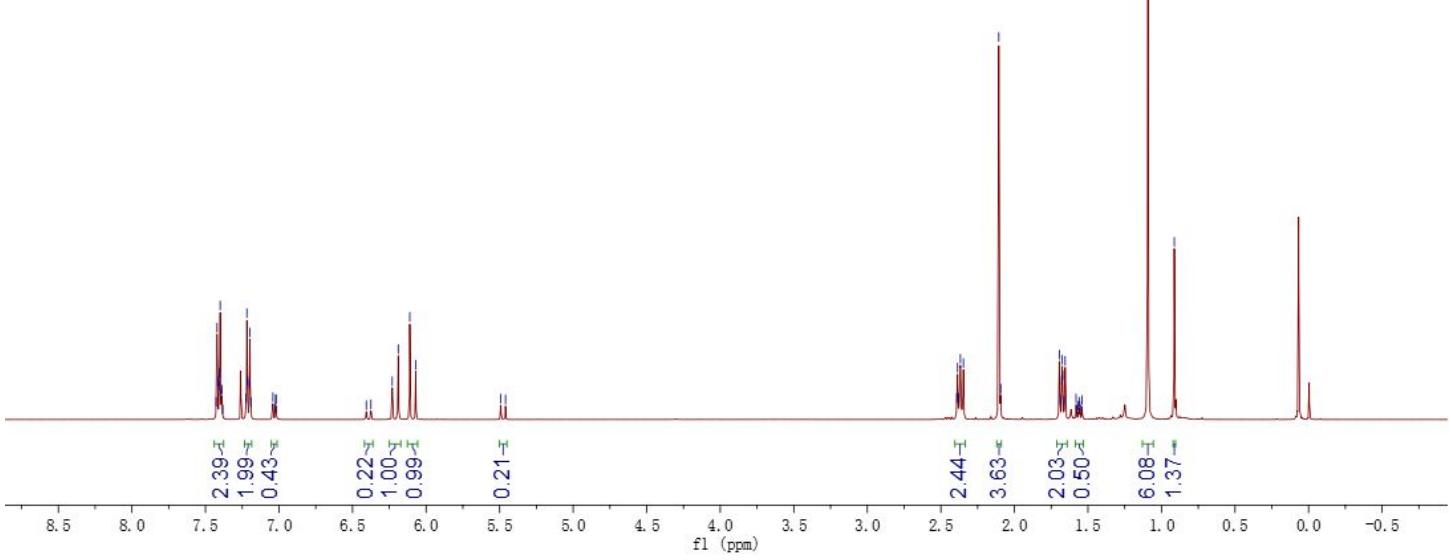

$\underset{\substack{1 \\ \stackrel{1}{N}}}{\stackrel{1}{2}}$

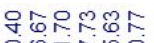

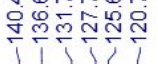

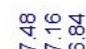

iㅛ

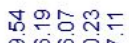

गुणु

$\underbrace{\mathrm{Br}}_{\mathbf{3} \mathbf{M}_{\mathrm{Me}}}$

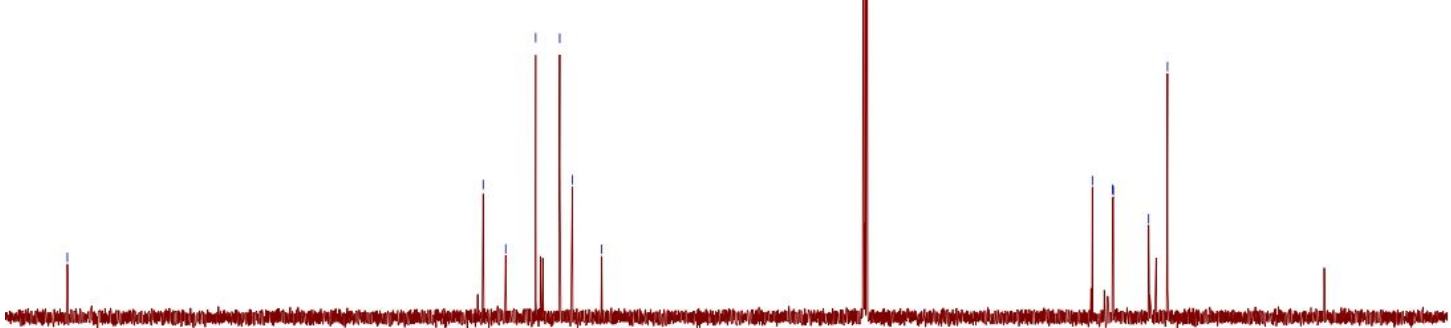

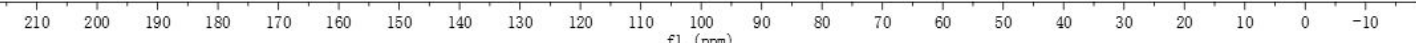



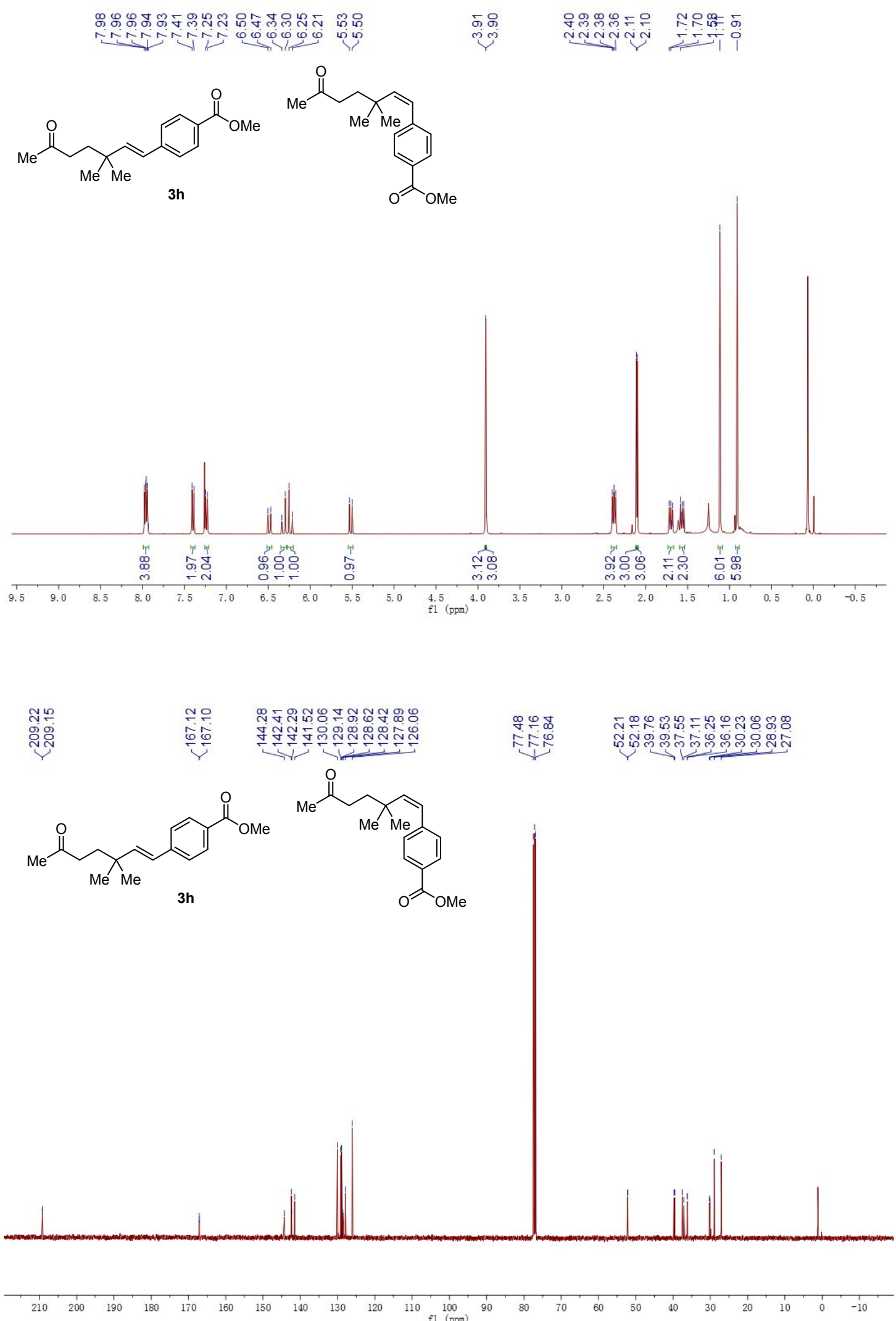

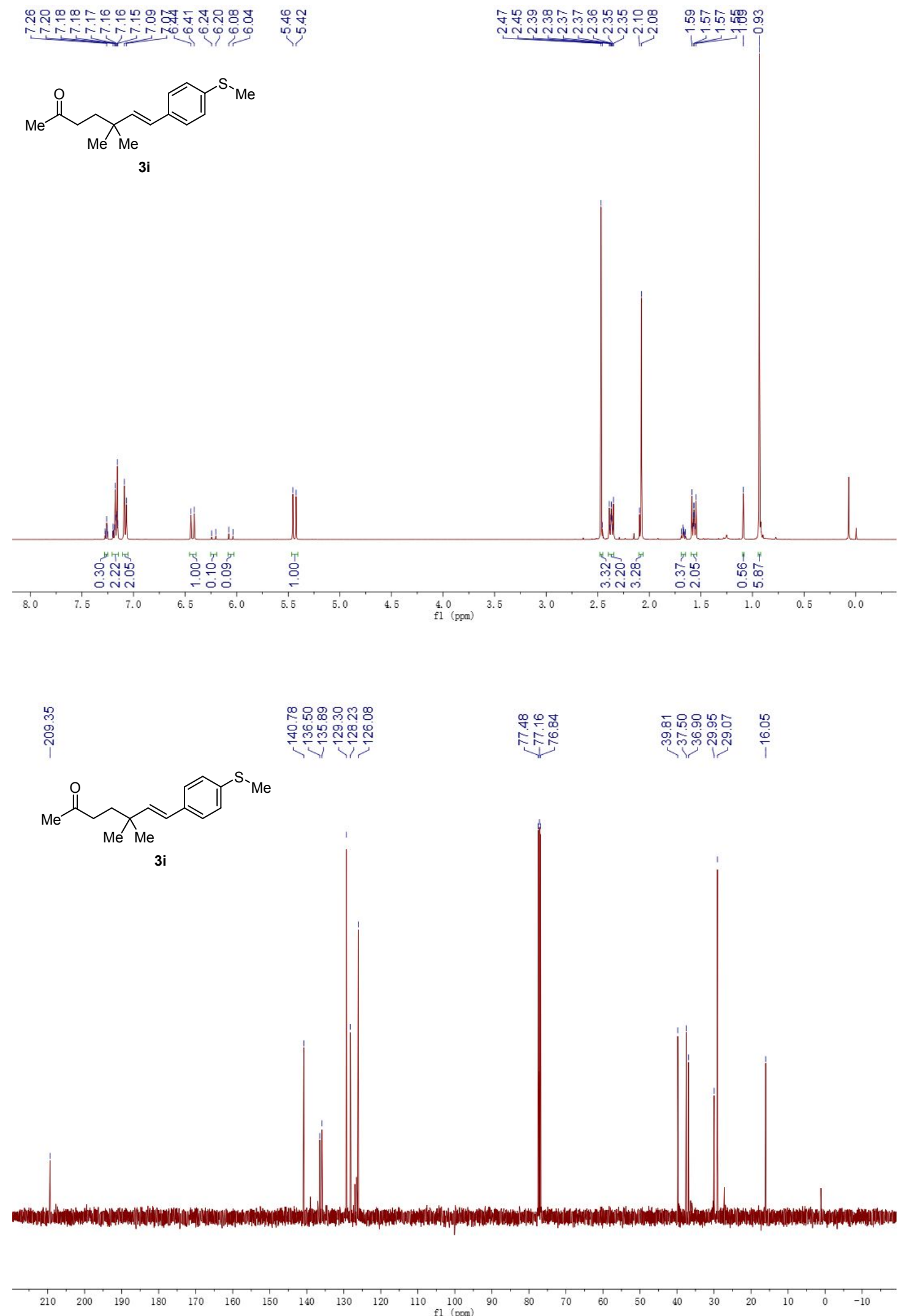
สุกำำำㅇำ

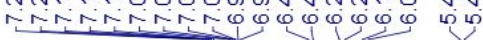

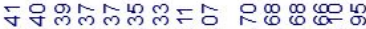

$\overbrace{M e}^{M e}$

3j

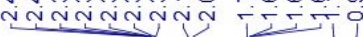

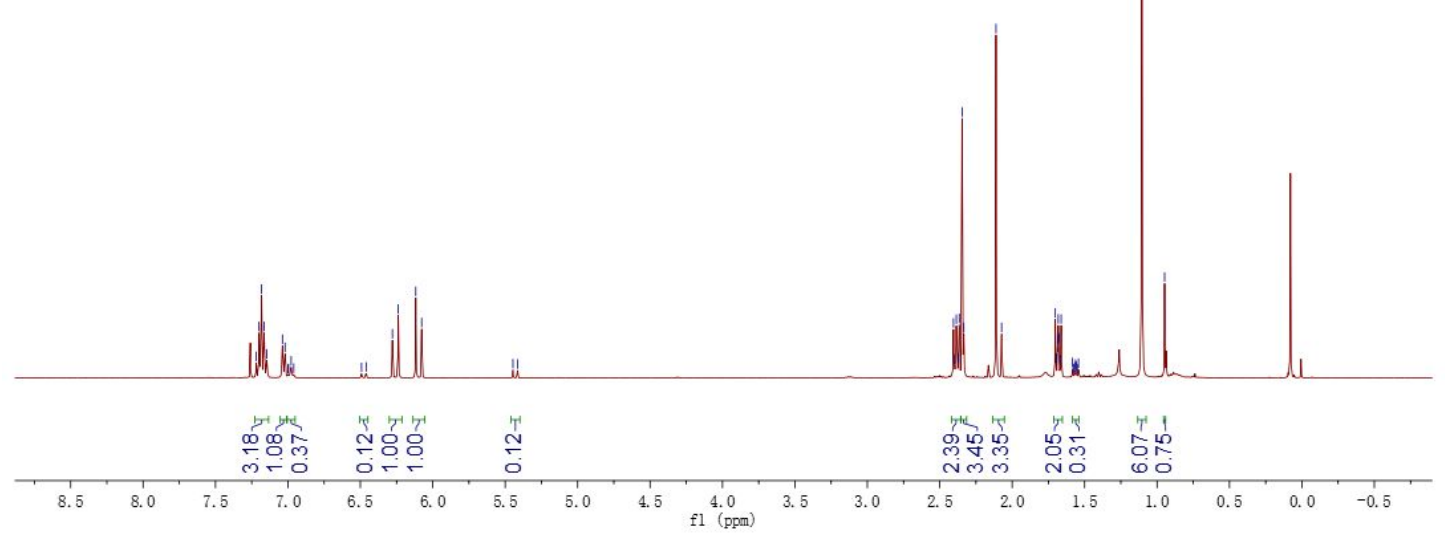

市<smiles>CC(=O)CCC(C)(C)C=Cc1cccc(C)c1</smiles>

3j

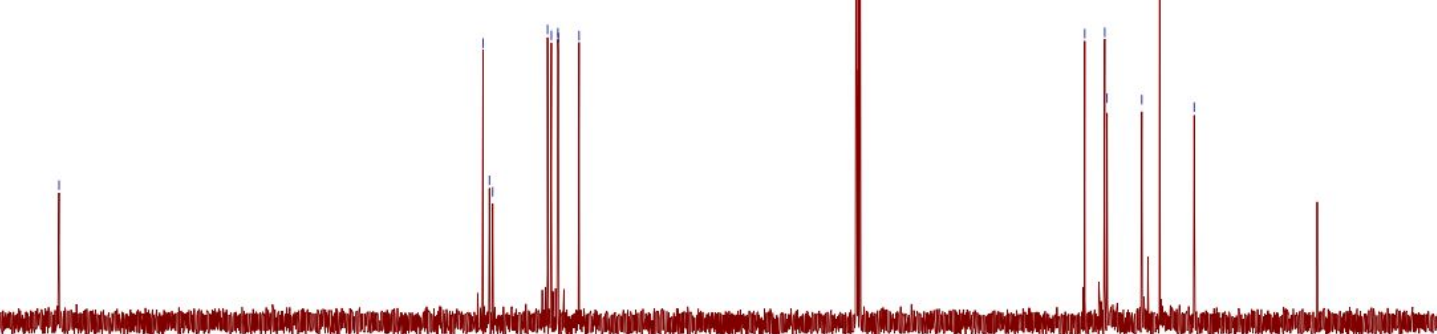

$\begin{array}{lllllllllllll}210 & 200 & 190 & 180 & 170 & 160 & 150 & 140 & 130 & 120 & 110 & 100 & 90\end{array}$

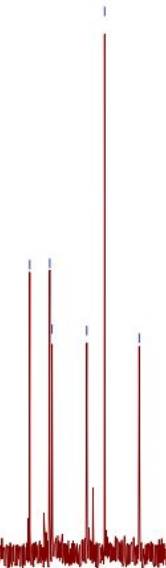




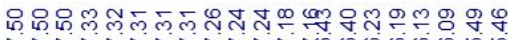

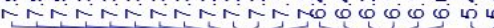

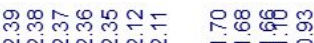

$\overbrace{M e}$

3k

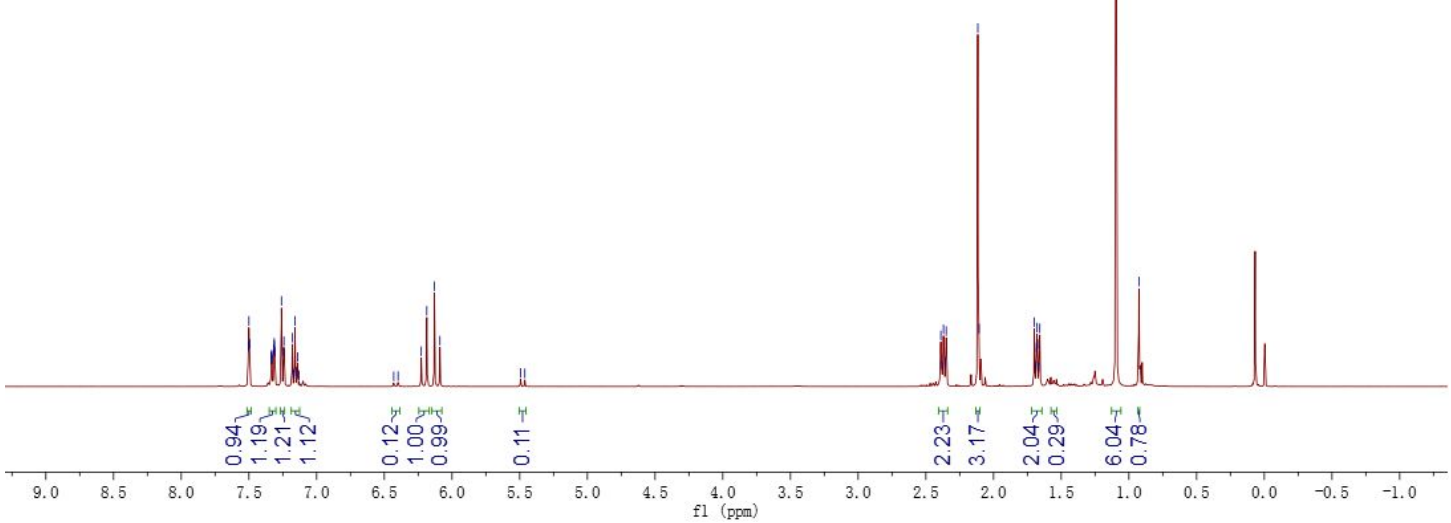

$\stackrel{\infty}{\circ}$

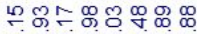

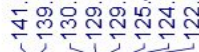

$\stackrel{\infty}{\infty} \stackrel{\infty}{\infty}$

นึก๊ำ

लुळ्্ु

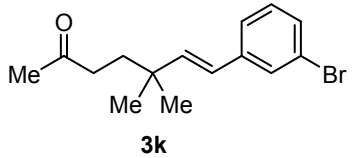

NFE

年

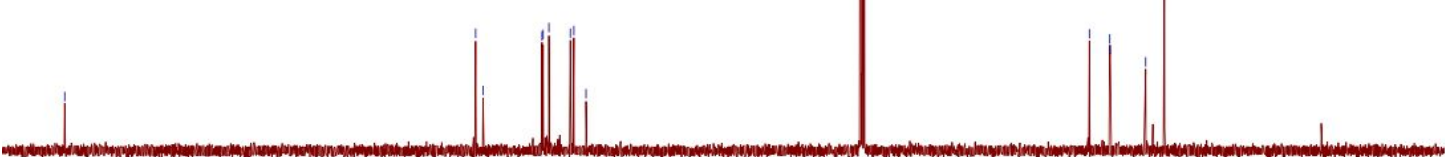

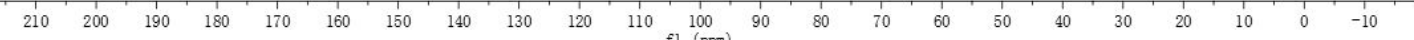




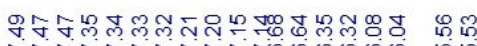

-iniminivo

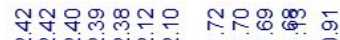

$\overbrace{M e}$

31

กู่nniñ

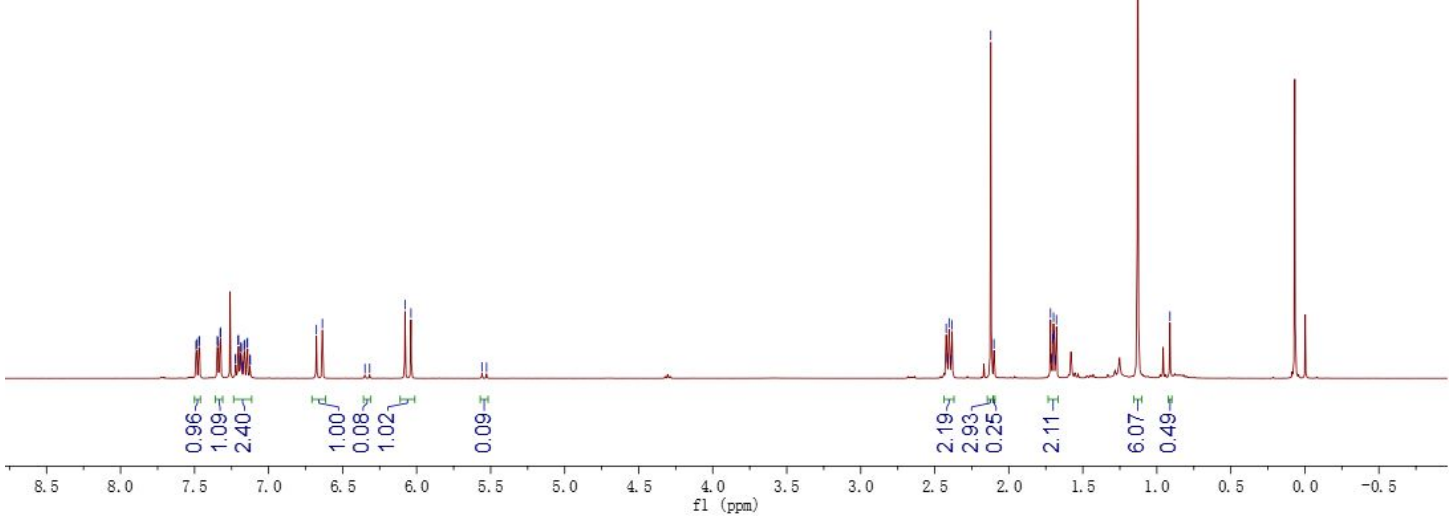

ले

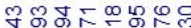

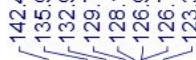

$\stackrel{\infty}{\infty} \div$

$\div$ a

䜤

ग्णुण्तुर<smiles>CC(=O)CCC(C)(C)/C=C/c1ccccc1Cl</smiles>

31 
<smiles>CC(=O)CCC(C)(C)/C=C\c1ccc2ccccc2c1</smiles>

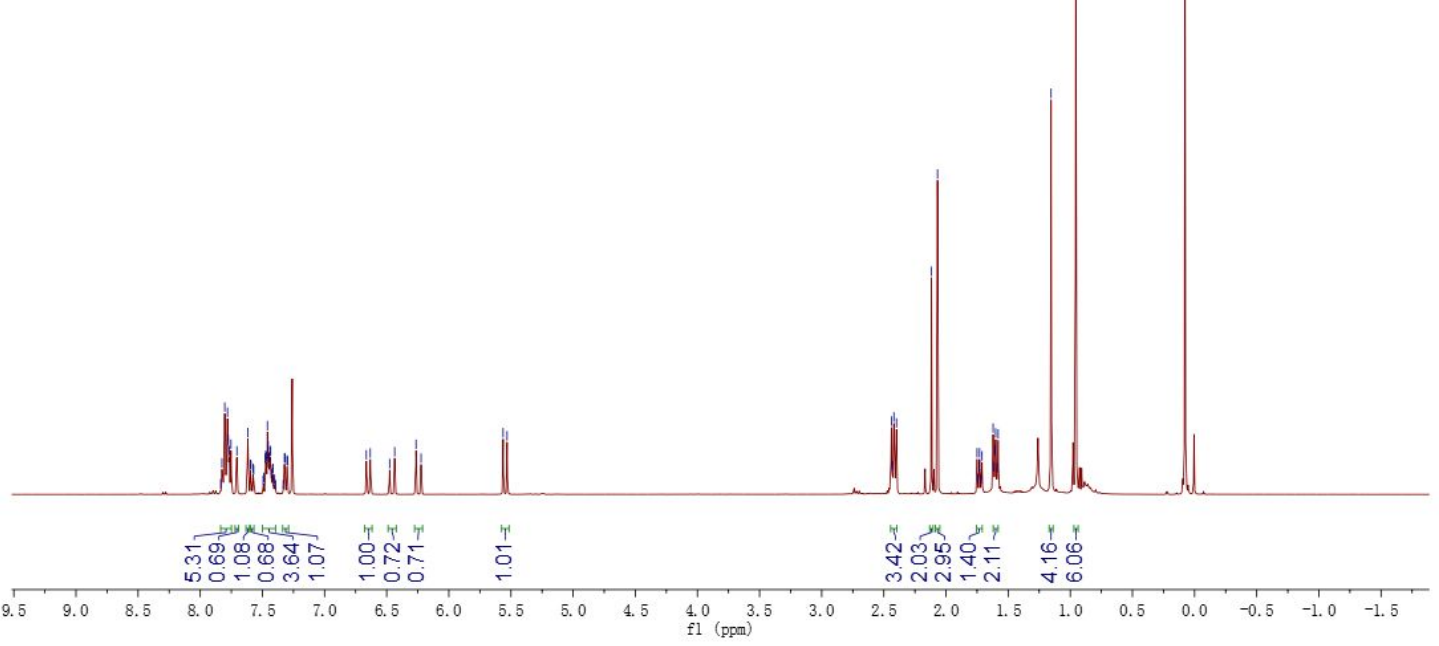

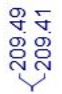

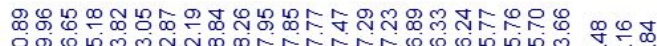

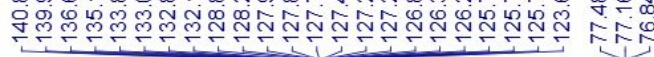<smiles>CC(=O)CCC1(C)C=CC2C=CC3C=CC=CC3C21</smiles><smiles>CC(=O)CCC(C)(C)C=Cc1ccc2ccccc2c1</smiles>

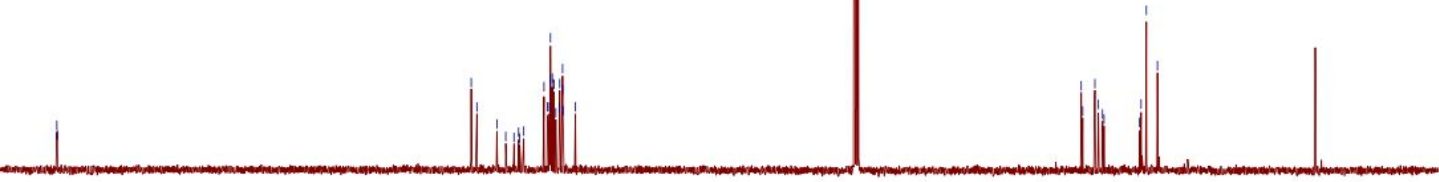


<smiles>CC(=O)CCC(C)(C)C=C(c1ccccc1)c1ccccc1</smiles>
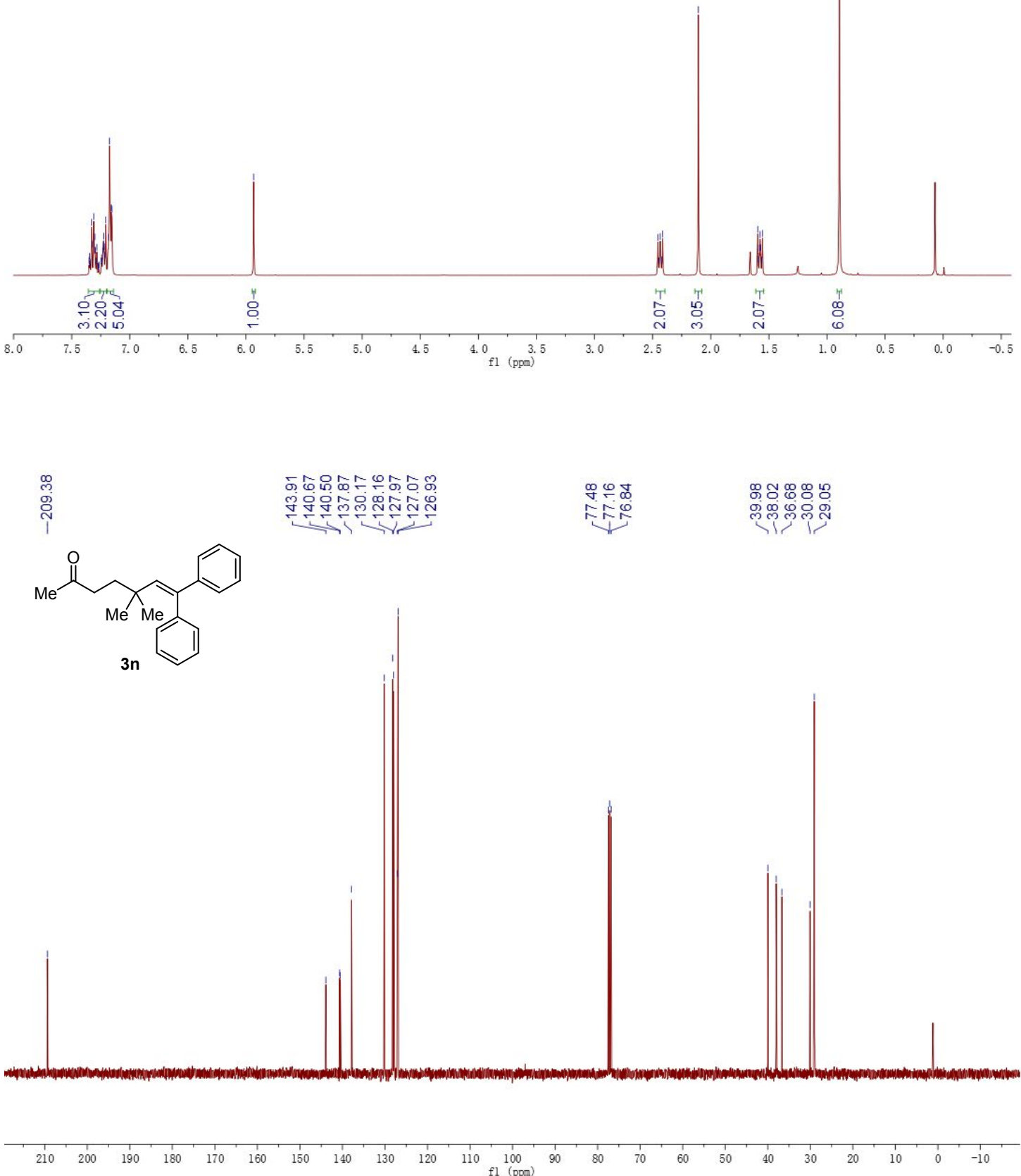


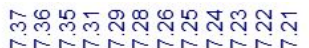

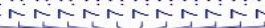

崖e

30

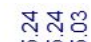

एँ

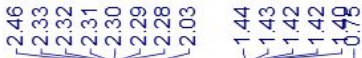

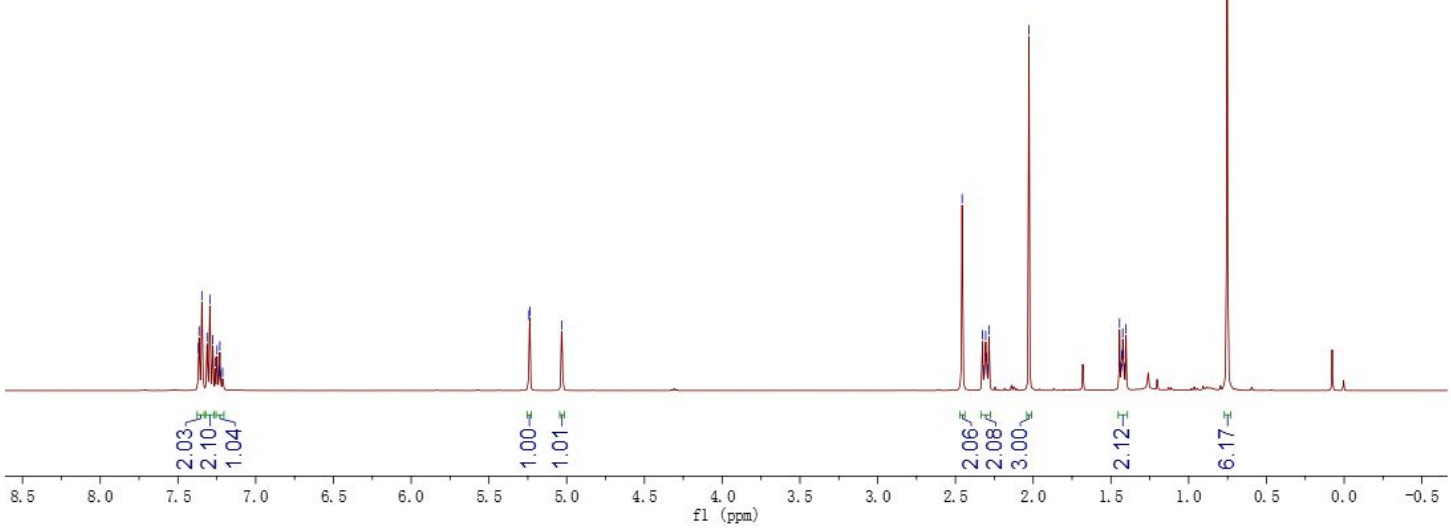<smiles>C=C(CC(C)(C)CCC(C)=O)c1ccccc1</smiles>

30

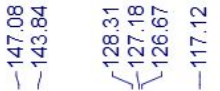

중

( )

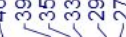

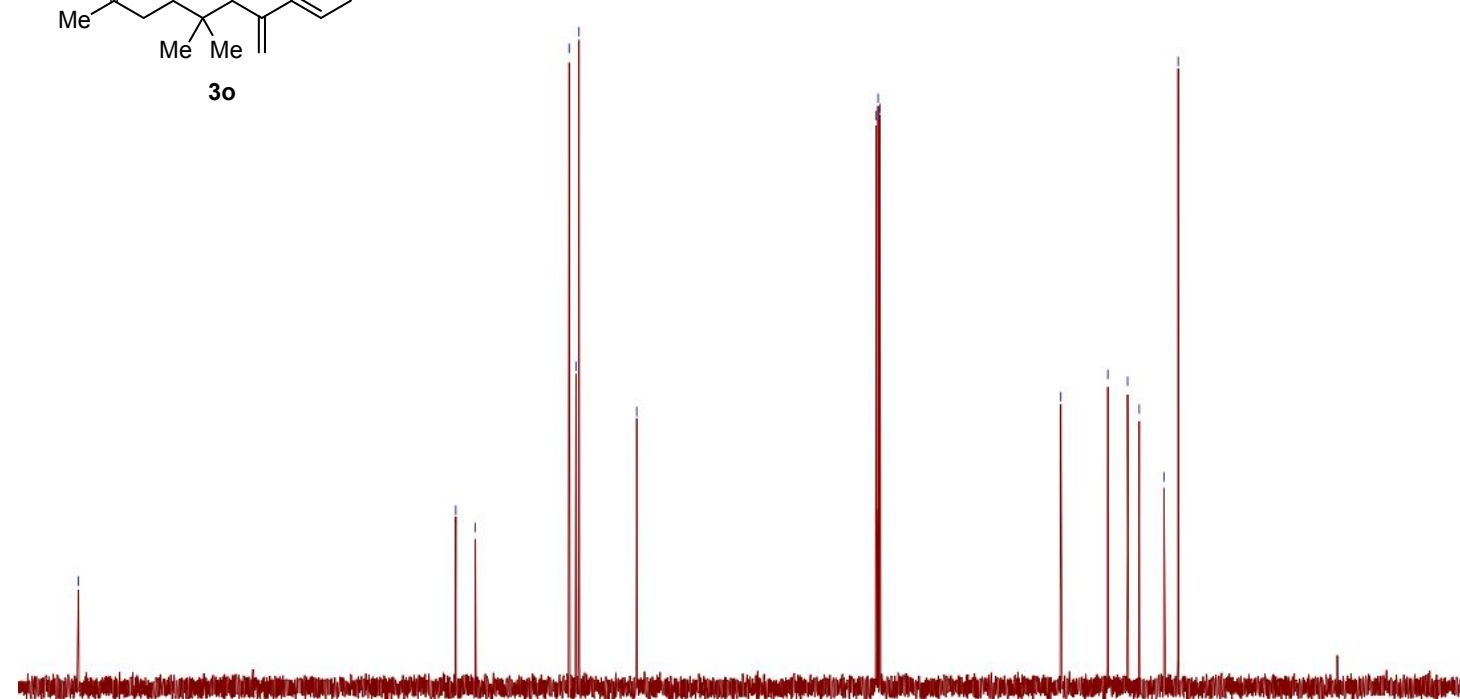

$\begin{array}{lllllllllllllllllllllllllllllllllllllll}1 & 1 & 200 & 190 & 180 & 170 & 160 & 150 & 140 & 130 & 120 & 110 & 100 & 90 & 80 & 70 & 60 & 50 & 40 & 30 & 20 & 10 & 0 & -10\end{array}$ 

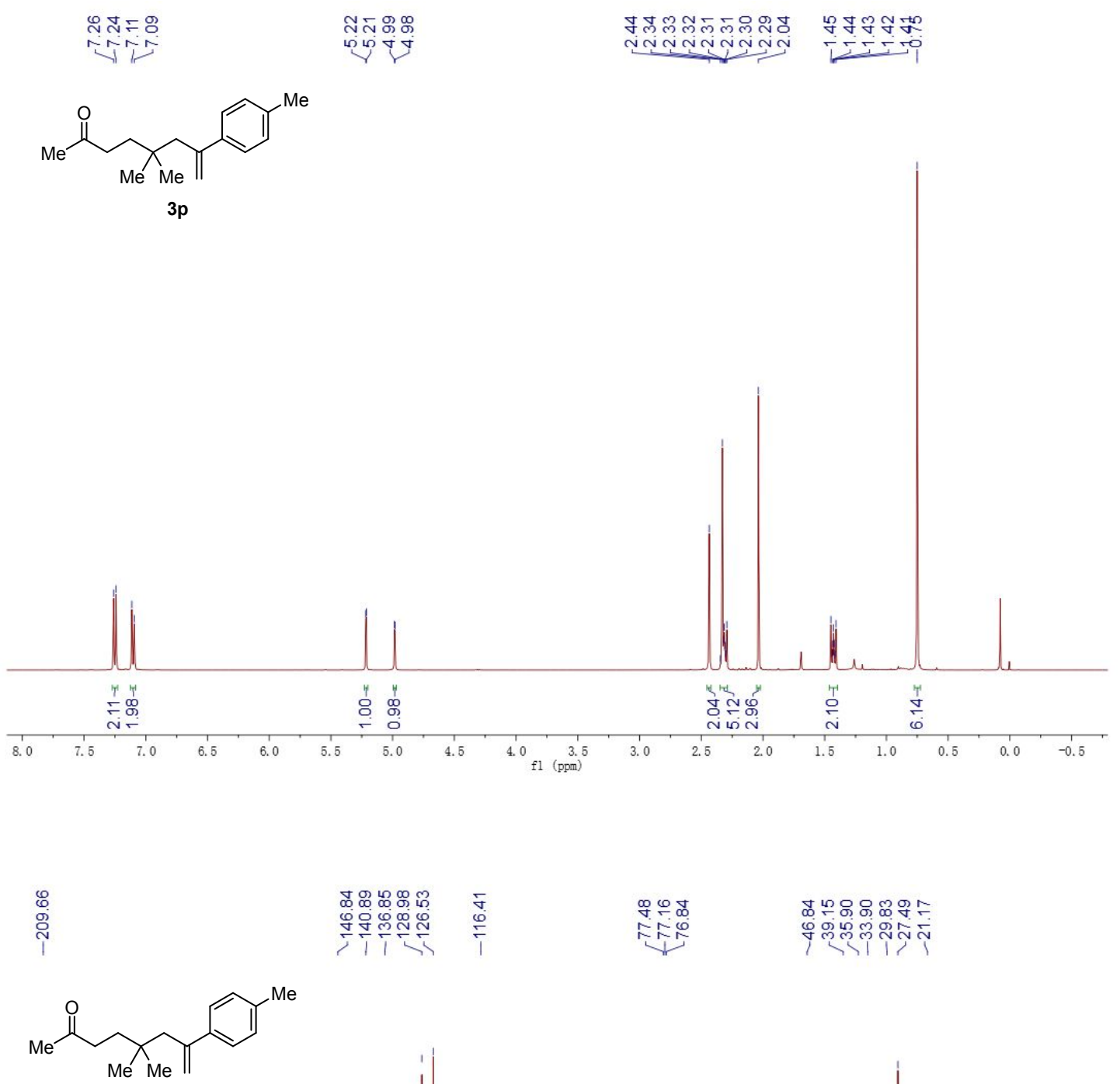

$3 p$

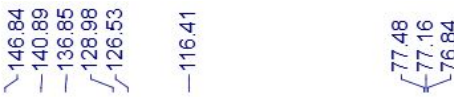

幽览

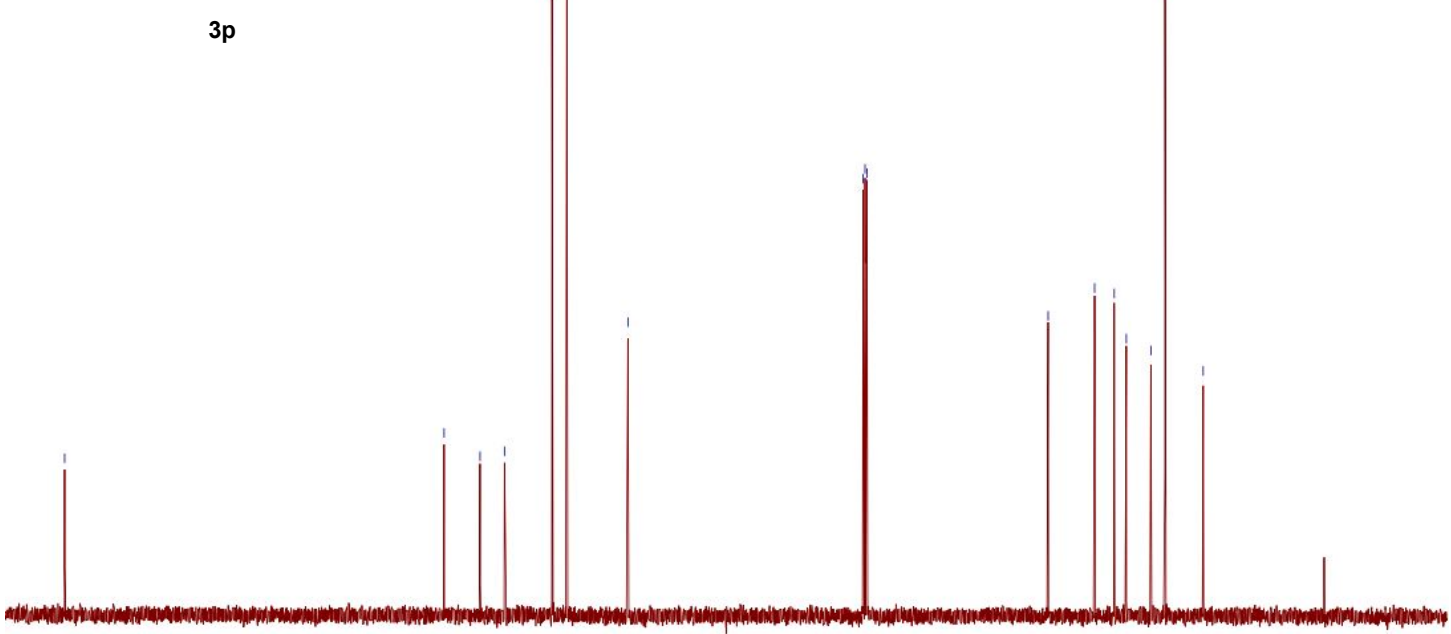

\begin{tabular}{rlllllllllllllllllllllllllll}
\hline & 1 \\
210 & 200 & 190 & 180 & 170 & 160 & 150 & 140 & 130 & 120 & 110 & 100 & 9 & 80 & 10 & 60 & 50 & 40 & 30 & 20 & 10 & 0 & -10
\end{tabular} 

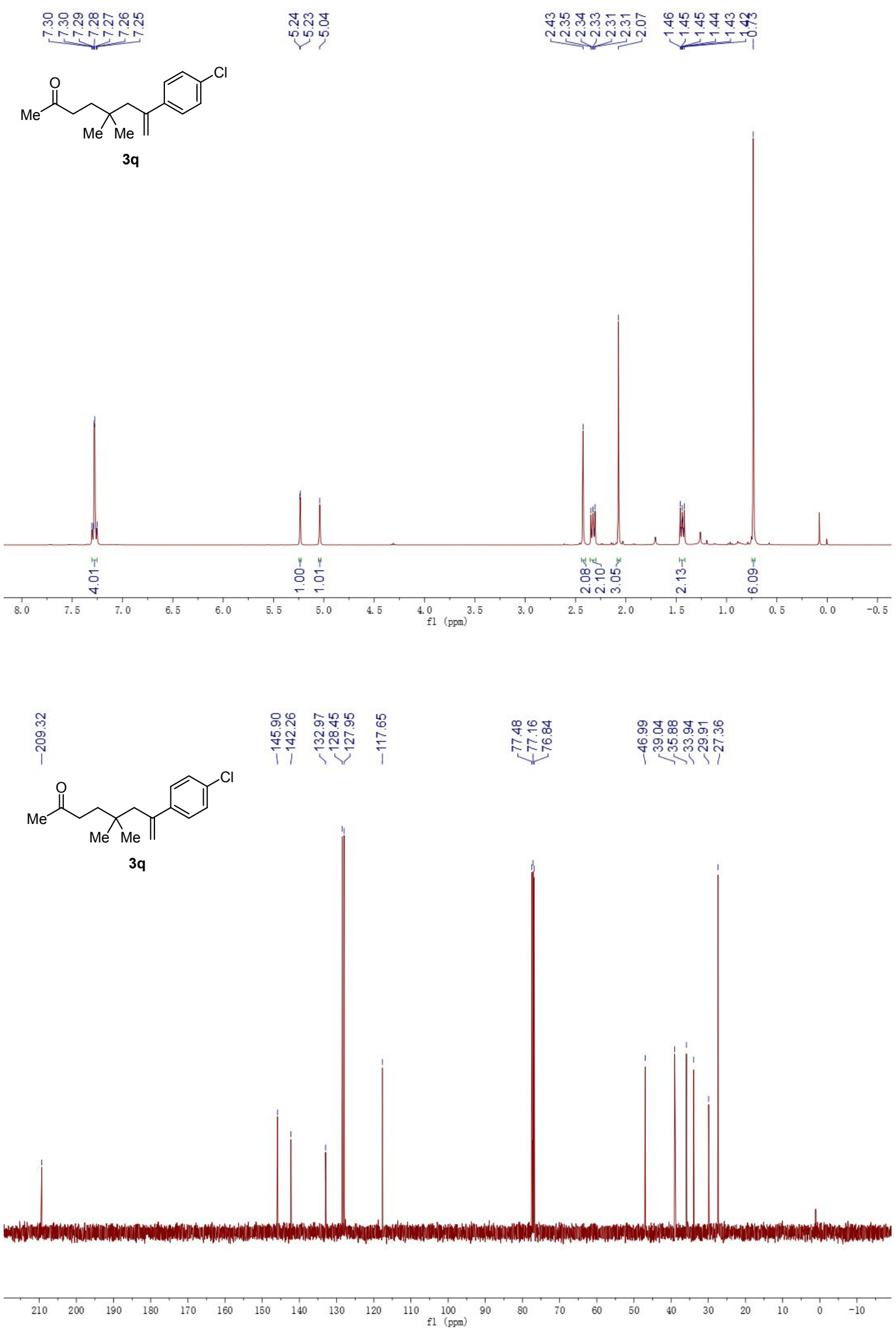

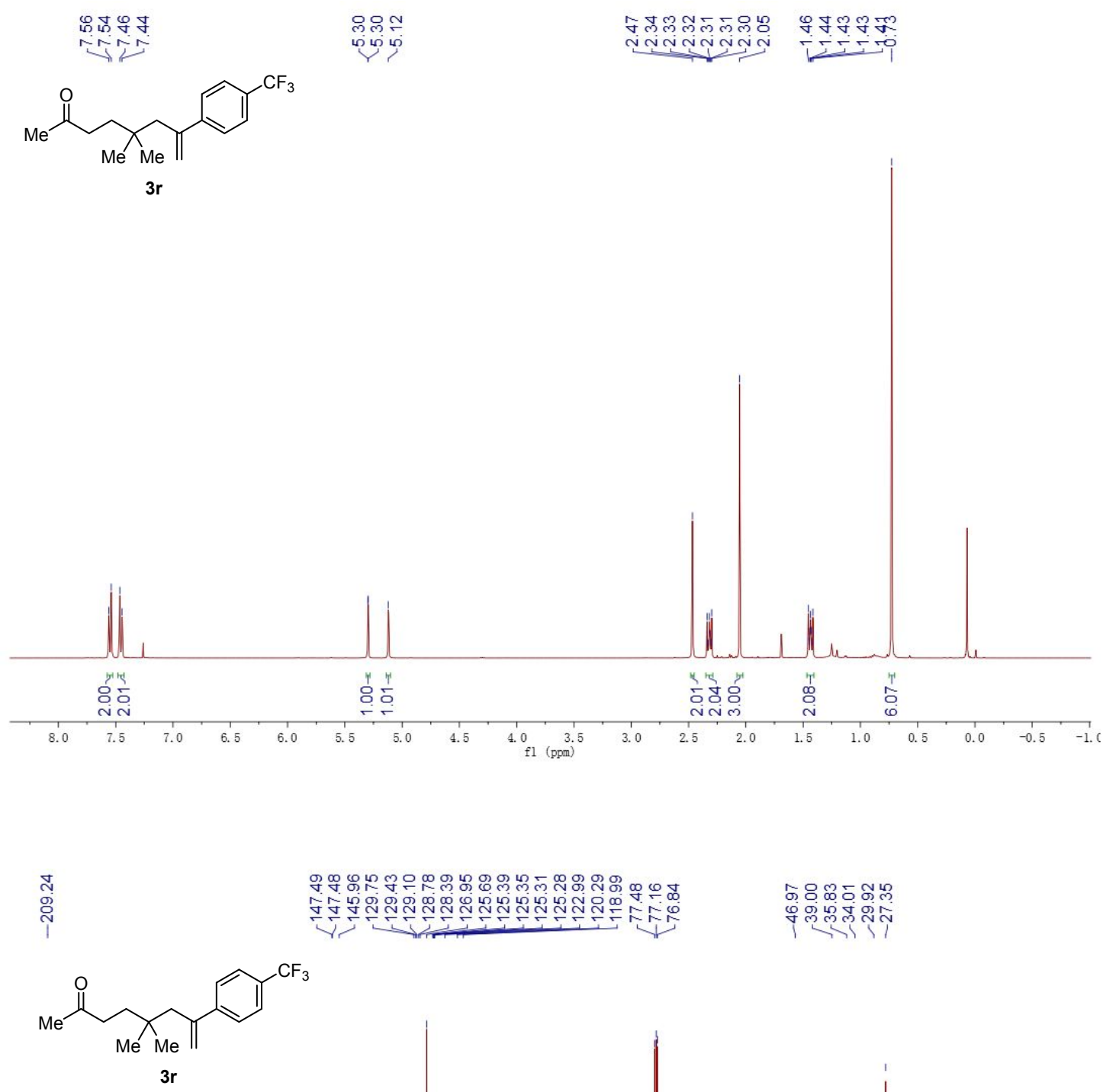

4.

वुल

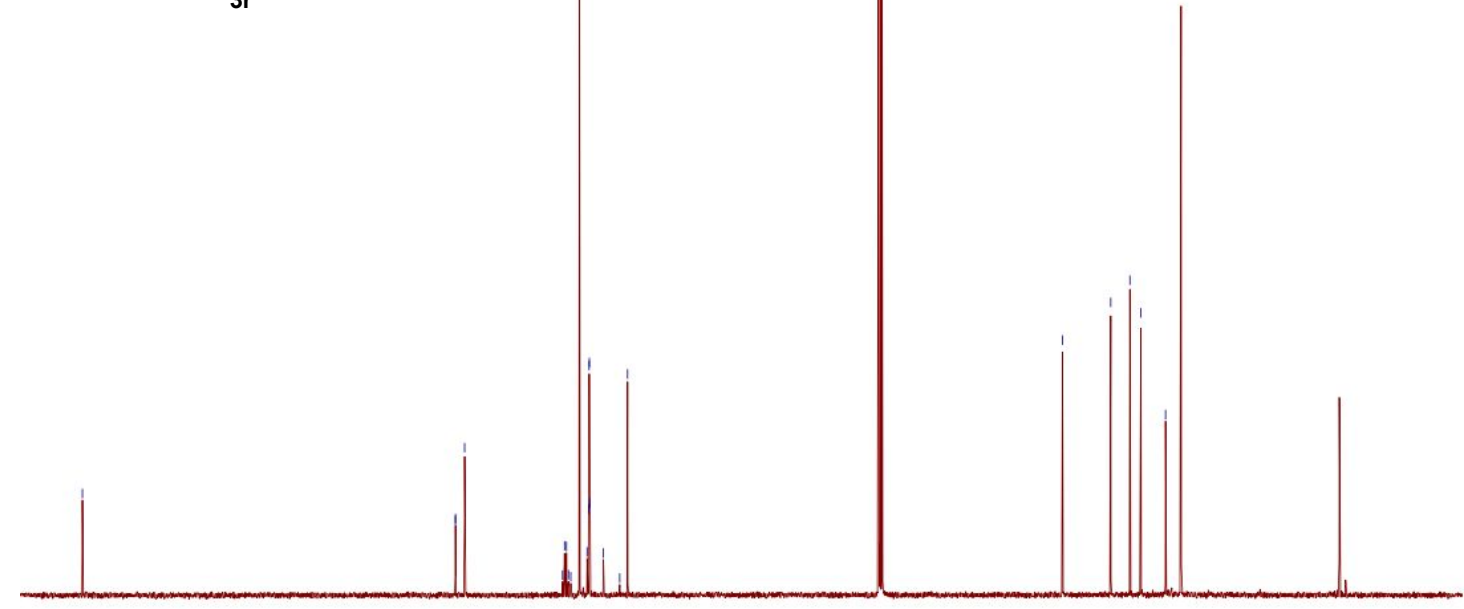

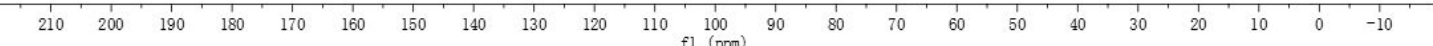



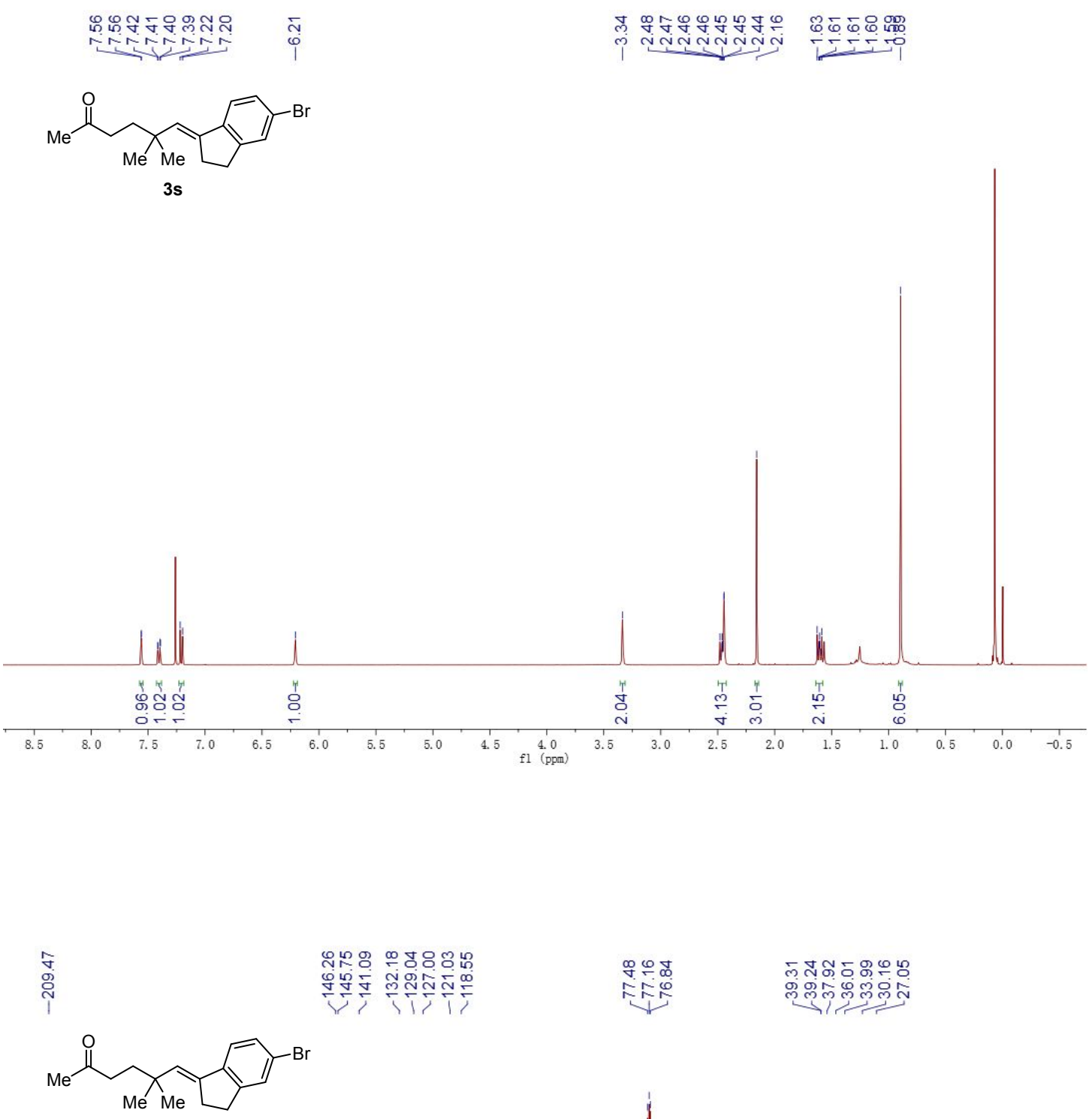

3s
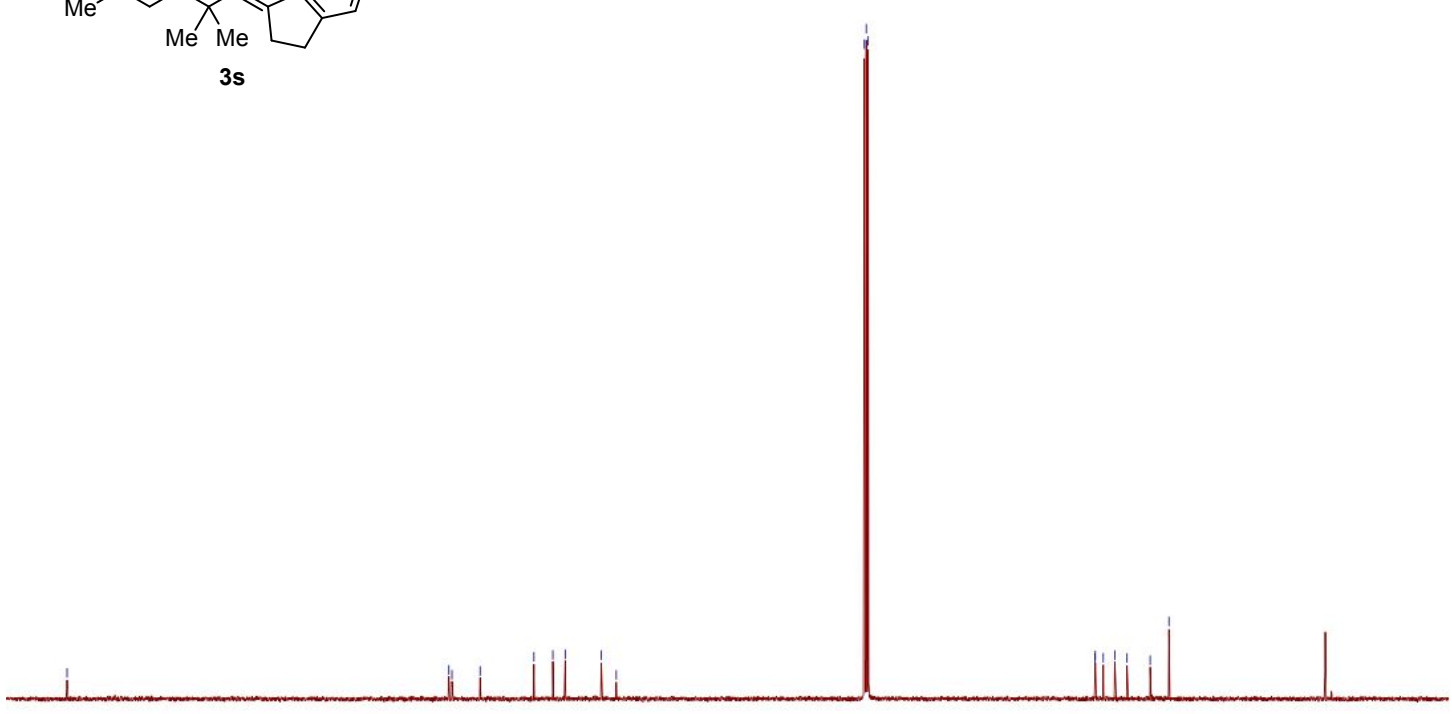

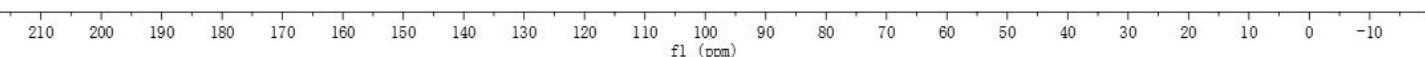


<smiles>C=C(CC(C)(C)CCC(C)=O)c1ccc2ccccc2c1</smiles>
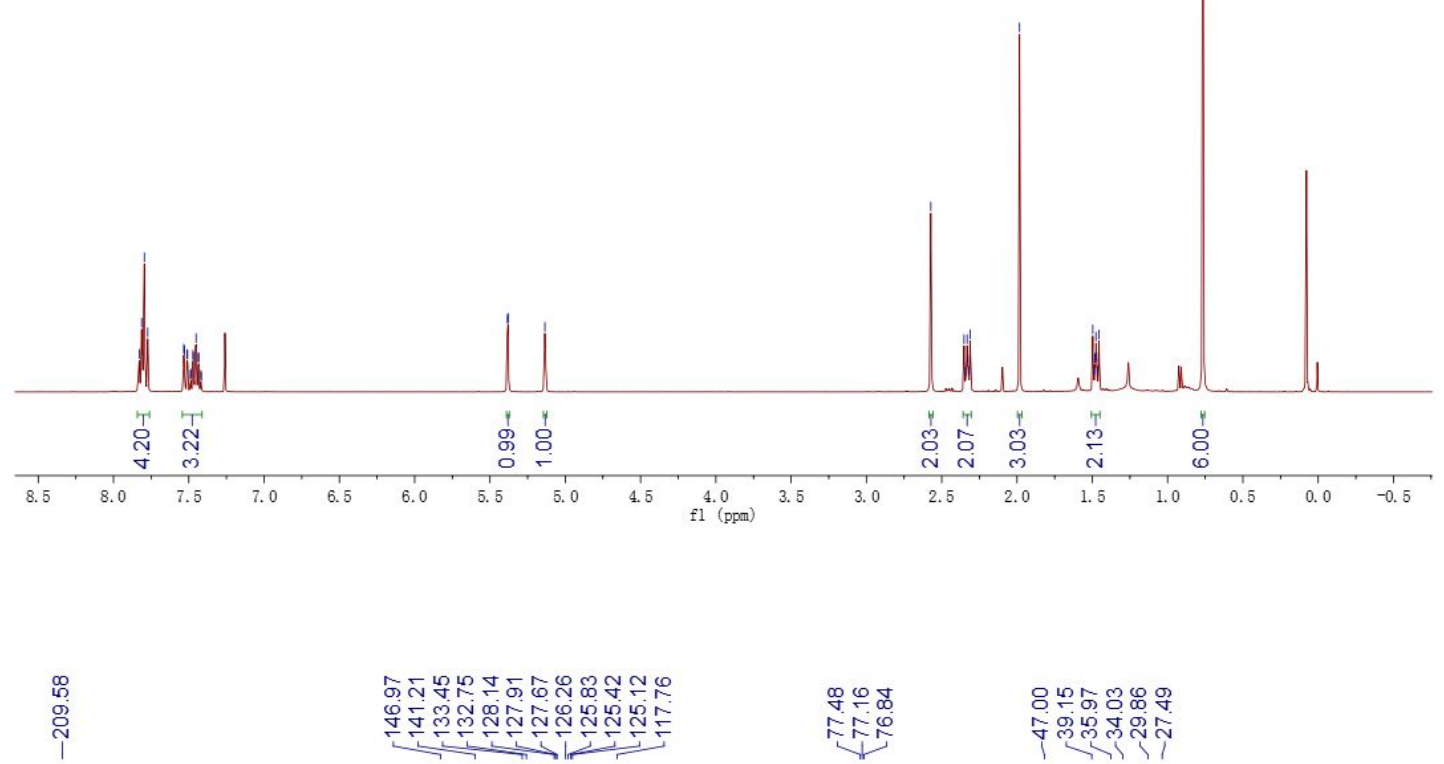<smiles>CC(=O)CCC(C)(C)CC(=[W])c1ccc2ccccc2c1</smiles>

$3 t$
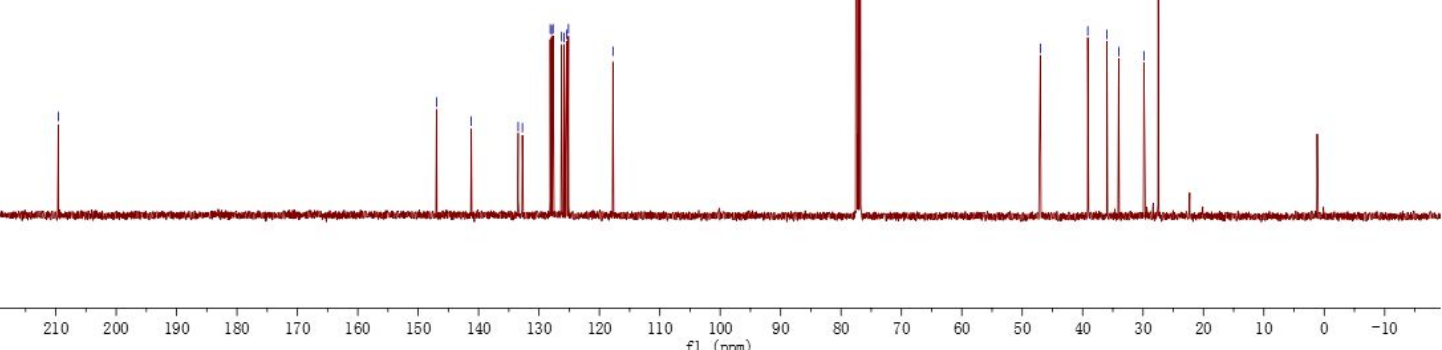

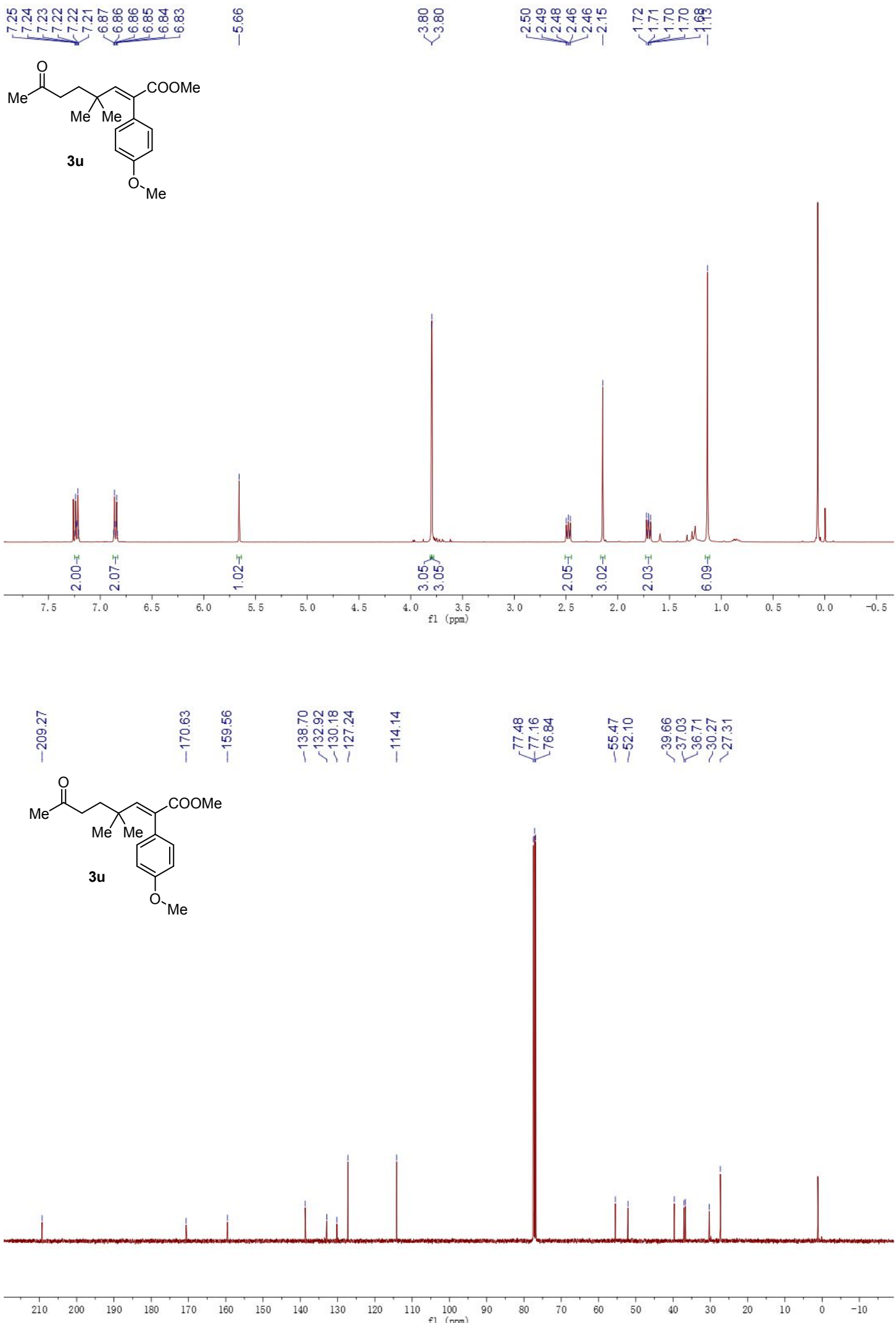


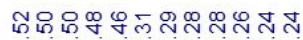

hankmanth

$\underbrace{M e}_{3 v}$

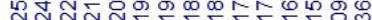

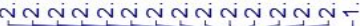

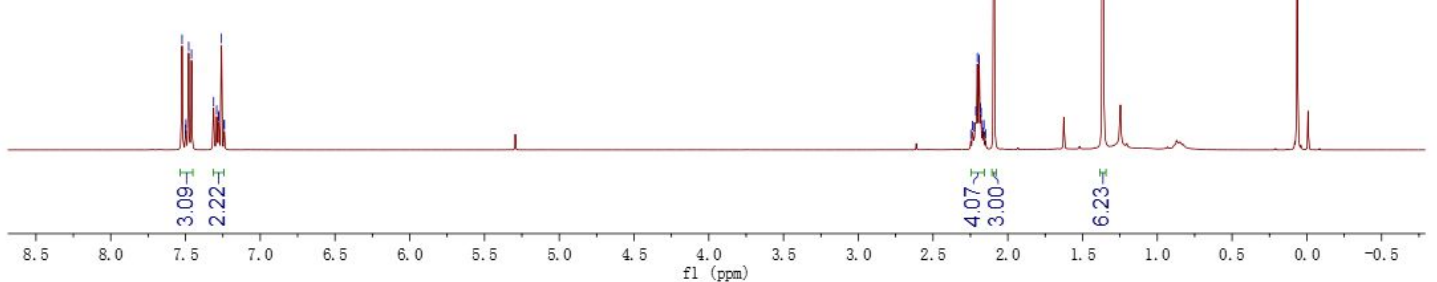
i
$\stackrel{1}{0}$
$\infty$

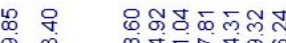
吕

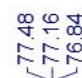

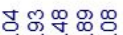
वृल्लूत्र
17

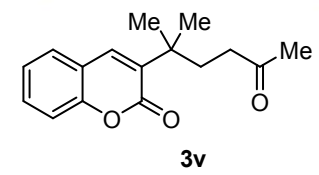




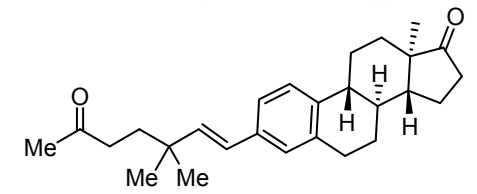

$3 w$
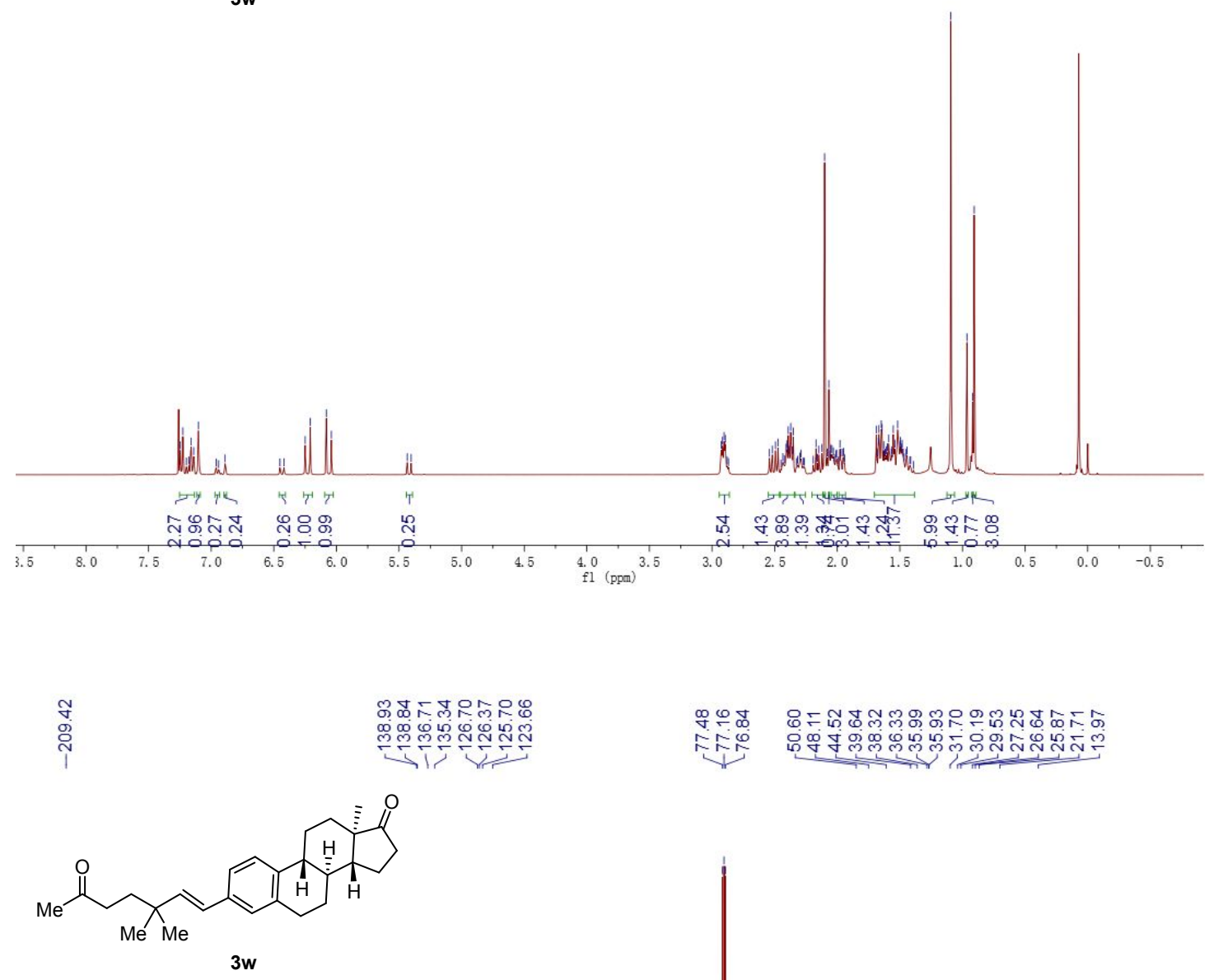

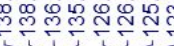

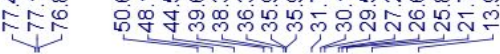
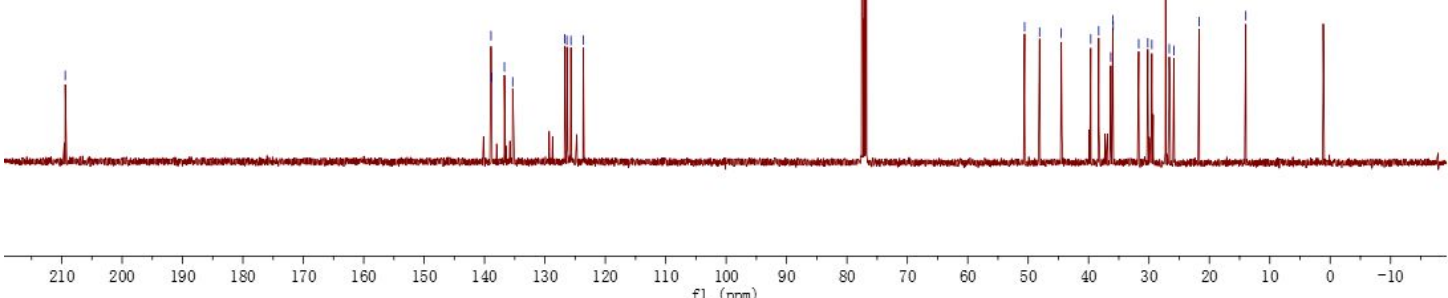
<smiles>CC(=O)CCC(C)(C)/C=C/c1ccc2c(c1)CCC1C2CC[C@]2(C)C1CC[C@H]2O</smiles>

$3 x$
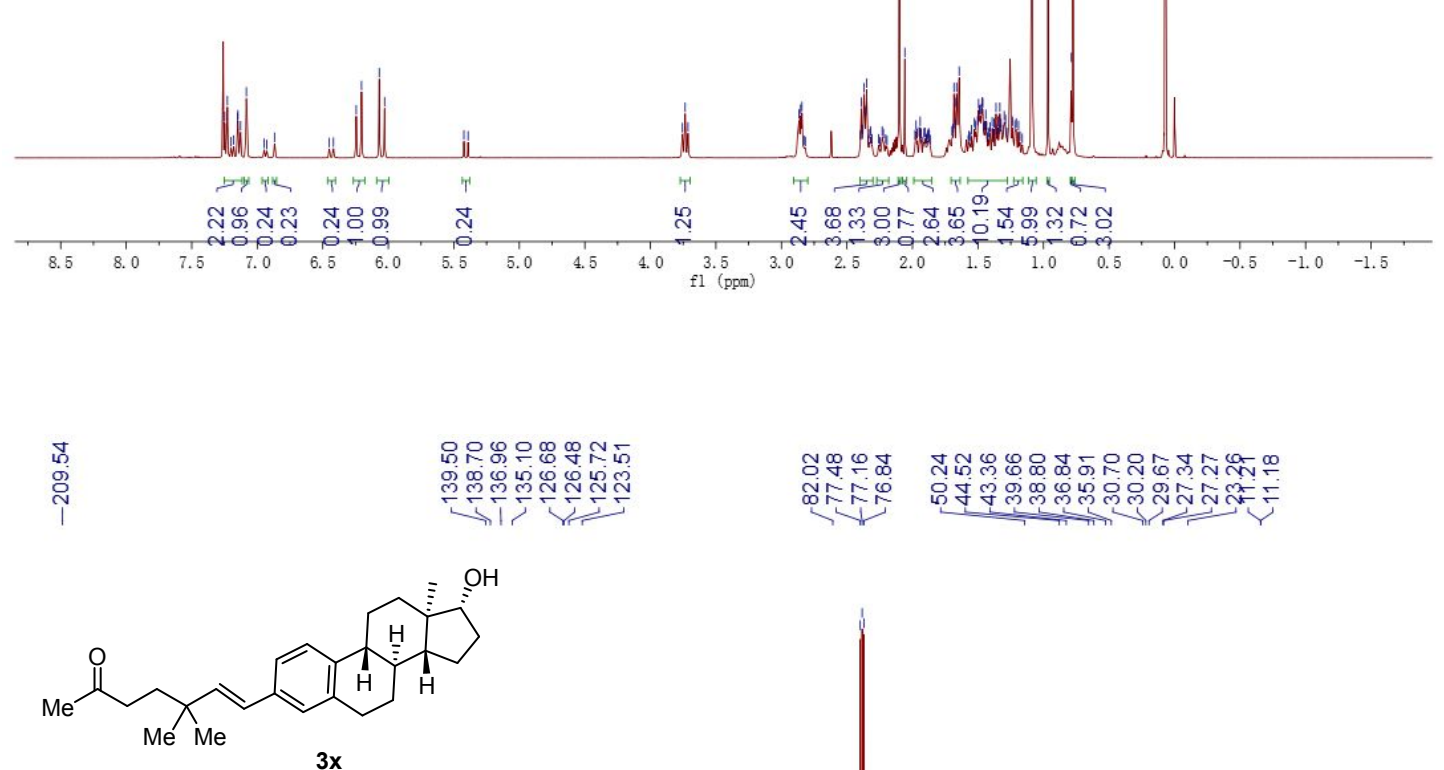

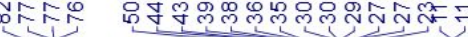

$\mathrm{OH}$ 


\section{${ }^{1} \mathrm{H}$ NMR and ${ }^{13} \mathrm{C}\left\{{ }^{1} \mathrm{H}\right\}$ NMR Spectra of Products 4}

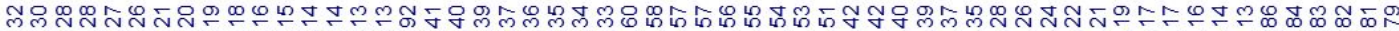

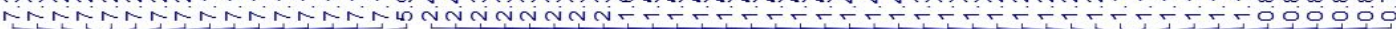<smiles>CCCCC(CC)C(=O)CCC(C)(C)C=C(c1ccccc1)c1ccccc1</smiles>

4a
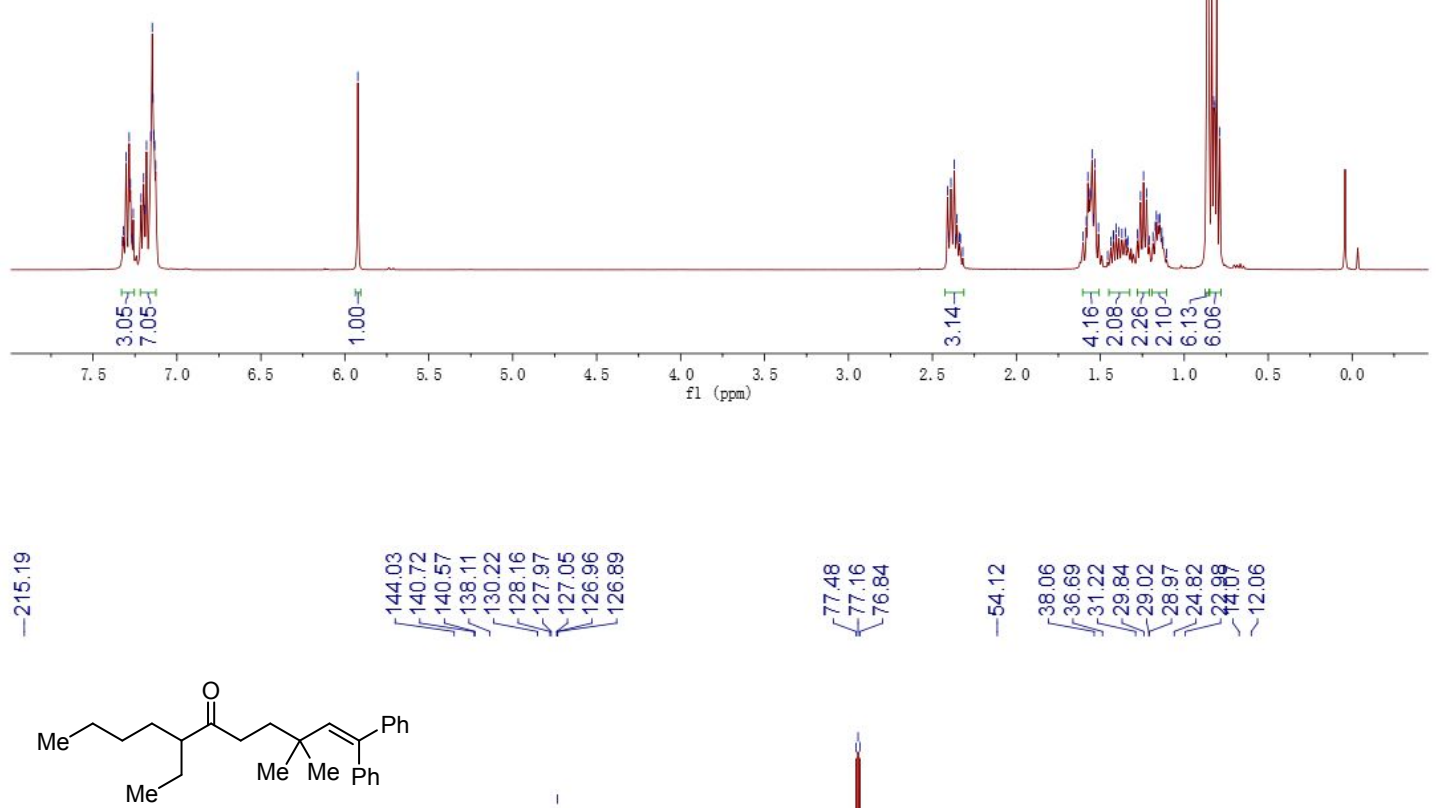

$4 a$

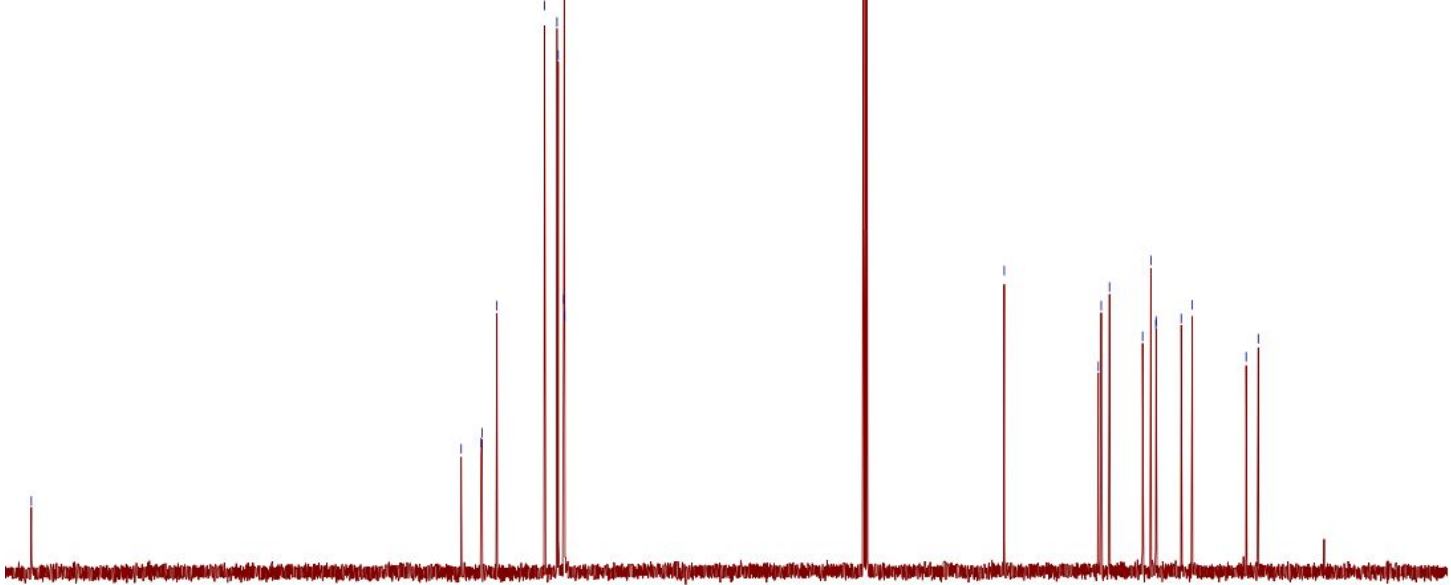

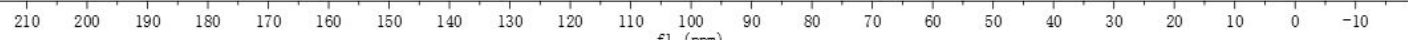




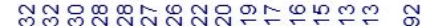

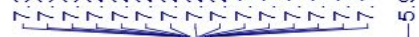<smiles>CC(C=C(c1ccccc1)c1ccccc1)(CCC(=O)C1CCCCC1)c1ccccc1</smiles>

4b

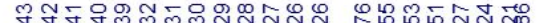

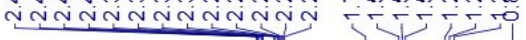
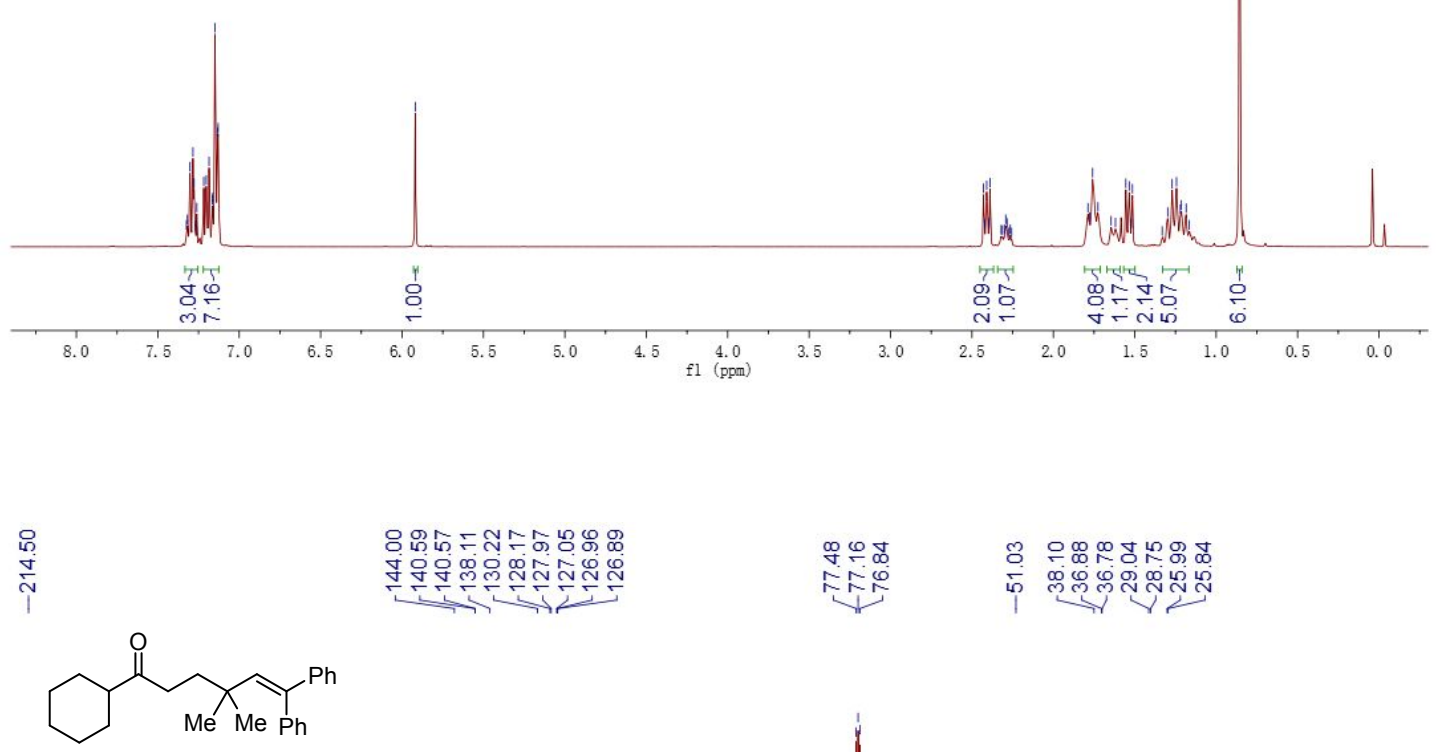

4b

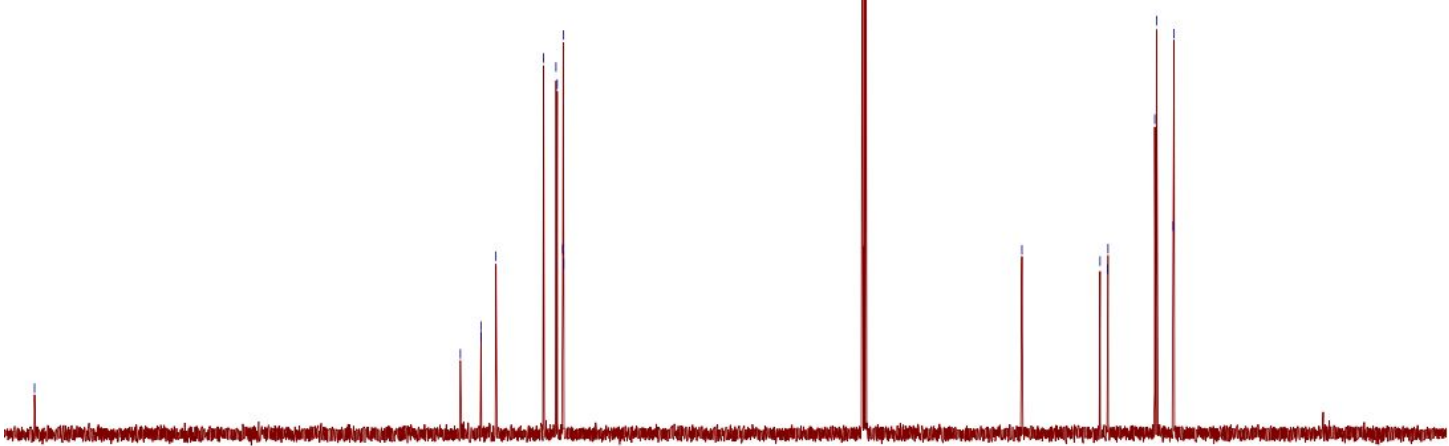


Pll

4c

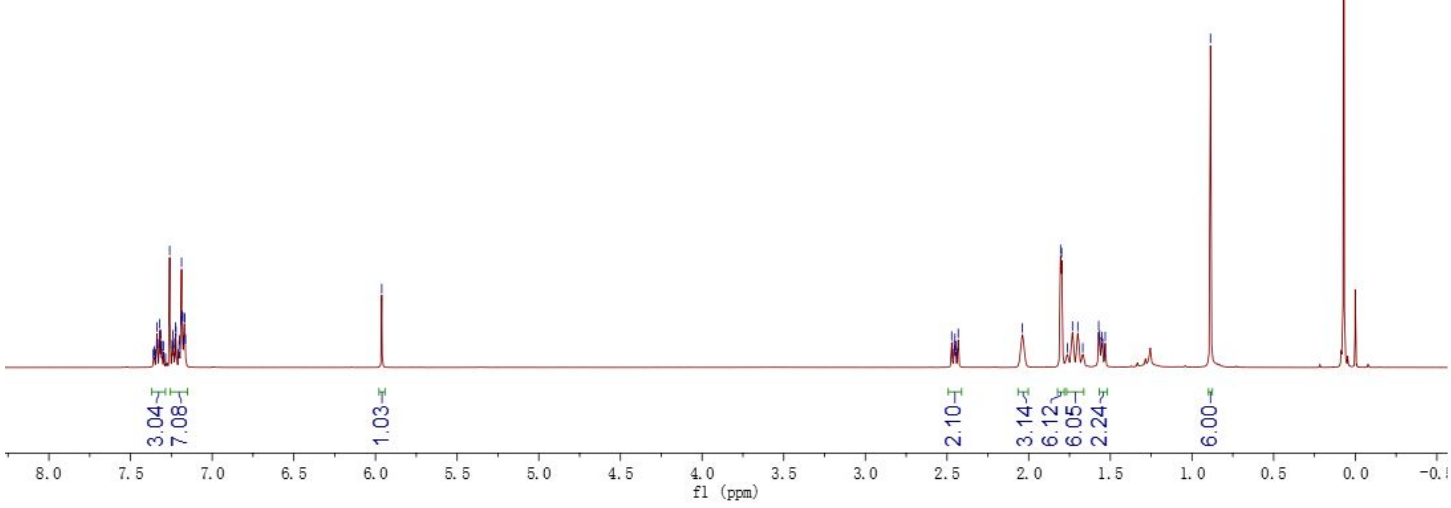

\begin{tabular}{|c|c|c|c|}
\hline 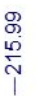 & 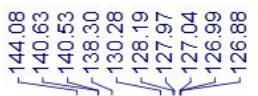 & 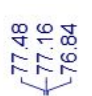 & 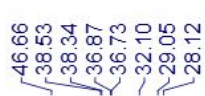 \\
\hline
\end{tabular}

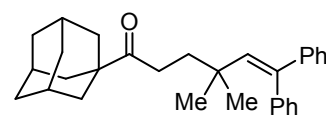

4c
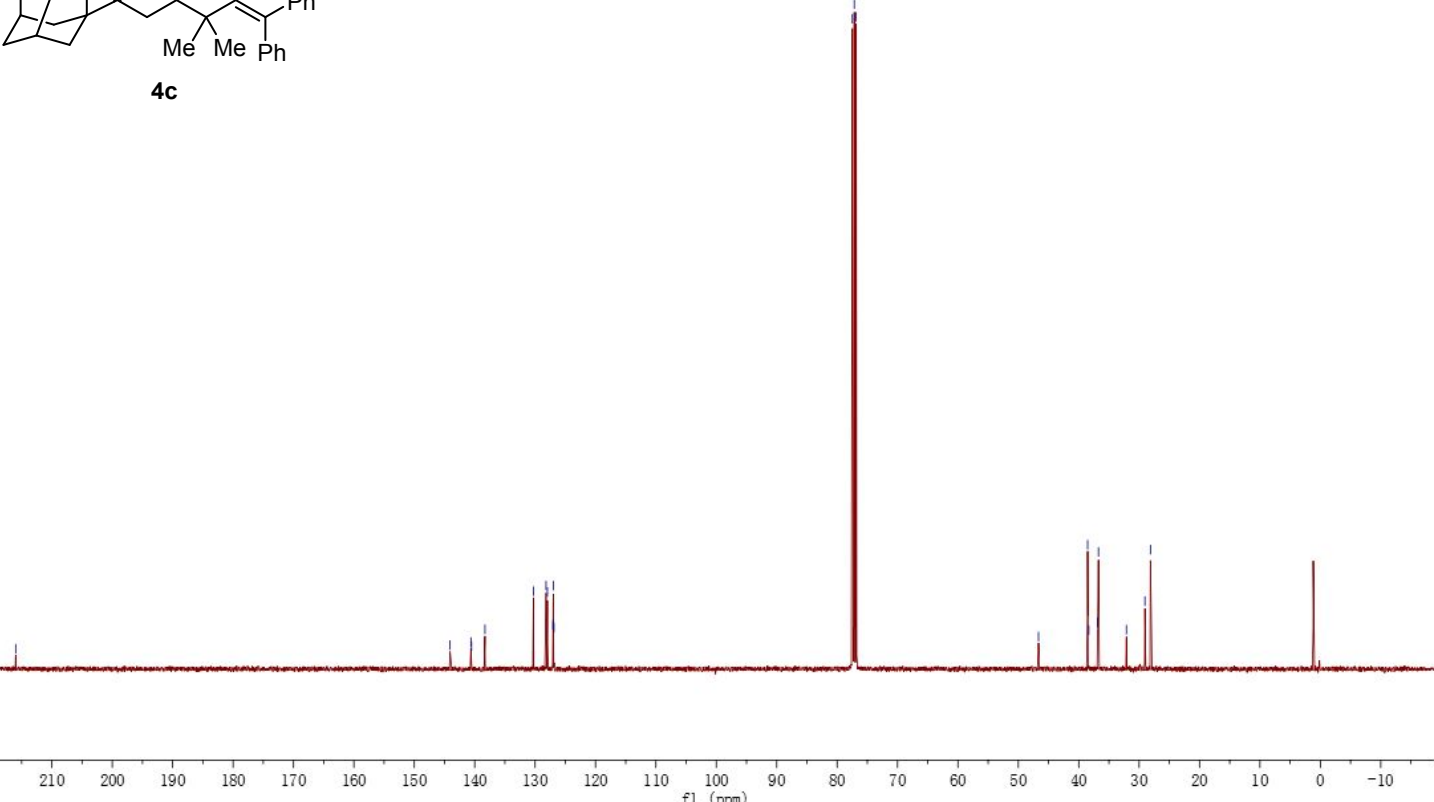

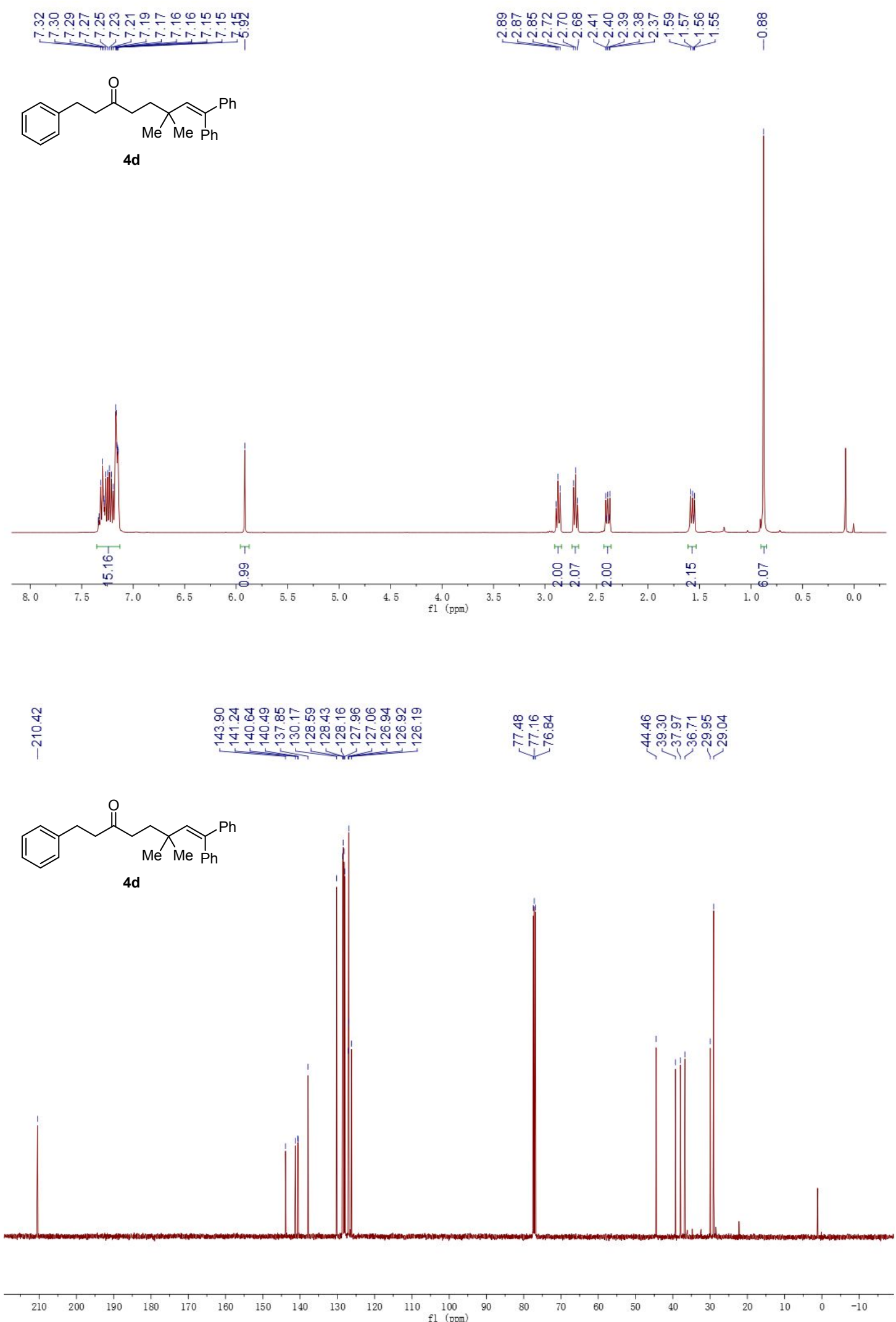
<smiles>CC(C)(C=C(c1ccccc1)c1ccccc1)CCC(=O)C1CCOCC1</smiles>

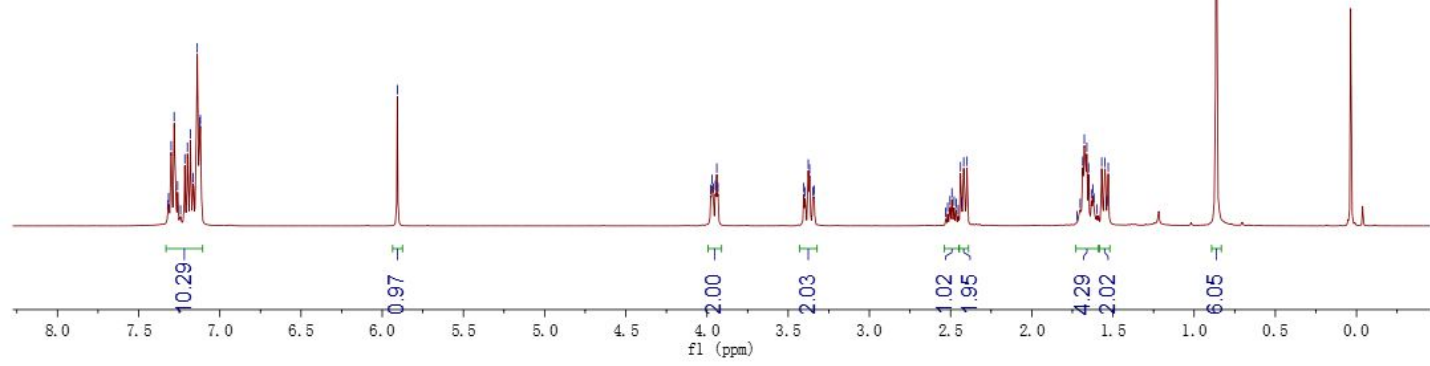

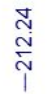<smiles>CC(C=C(c1ccccc1)c1ccccc1)(CCC(=O)C1CCOCC1)c1ccccc1</smiles>

$4 e$
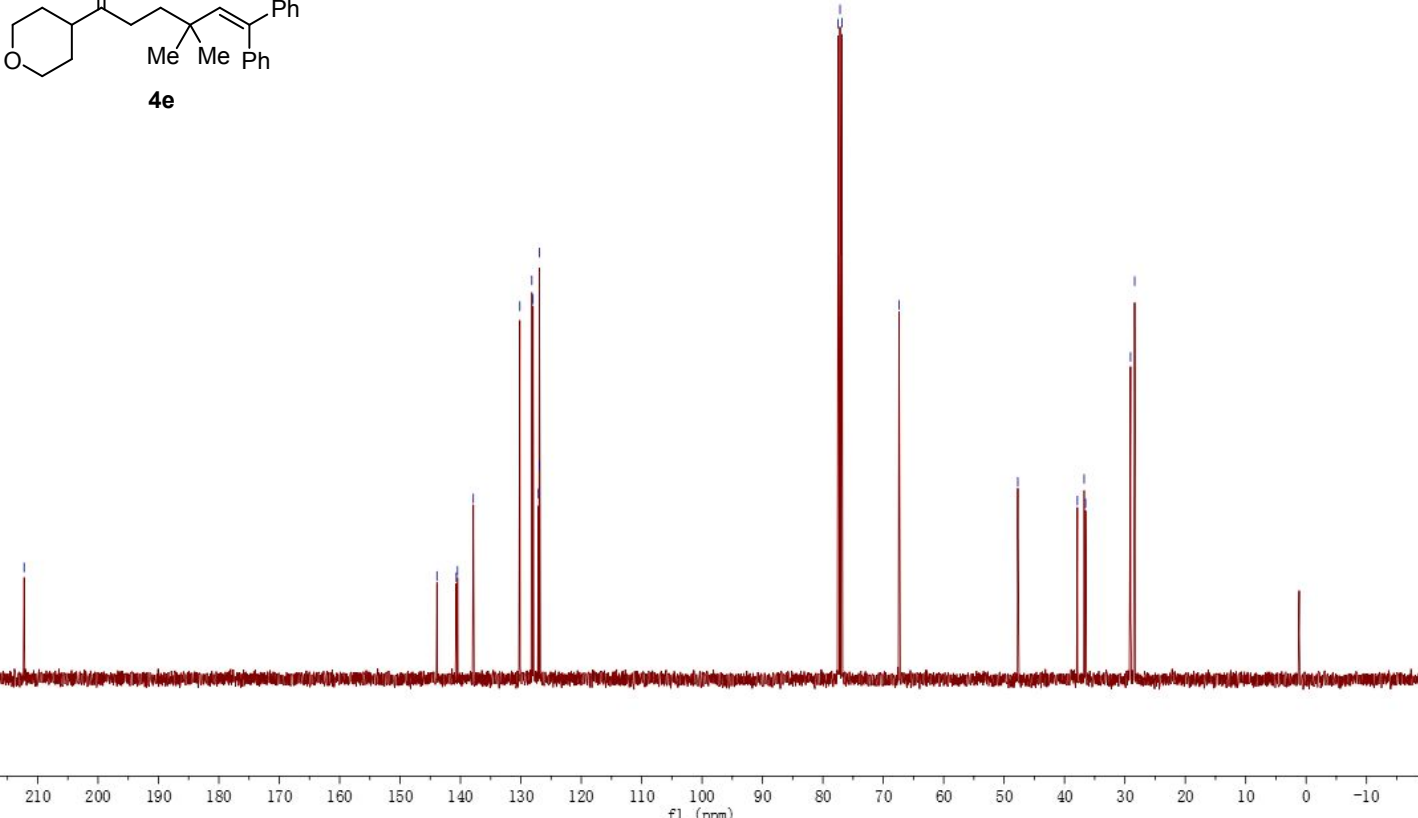
<smiles>CC(N)(C=C(c1ccccc1)c1ccccc1)CCC(=O)C1CCN([12F])CC1</smiles>
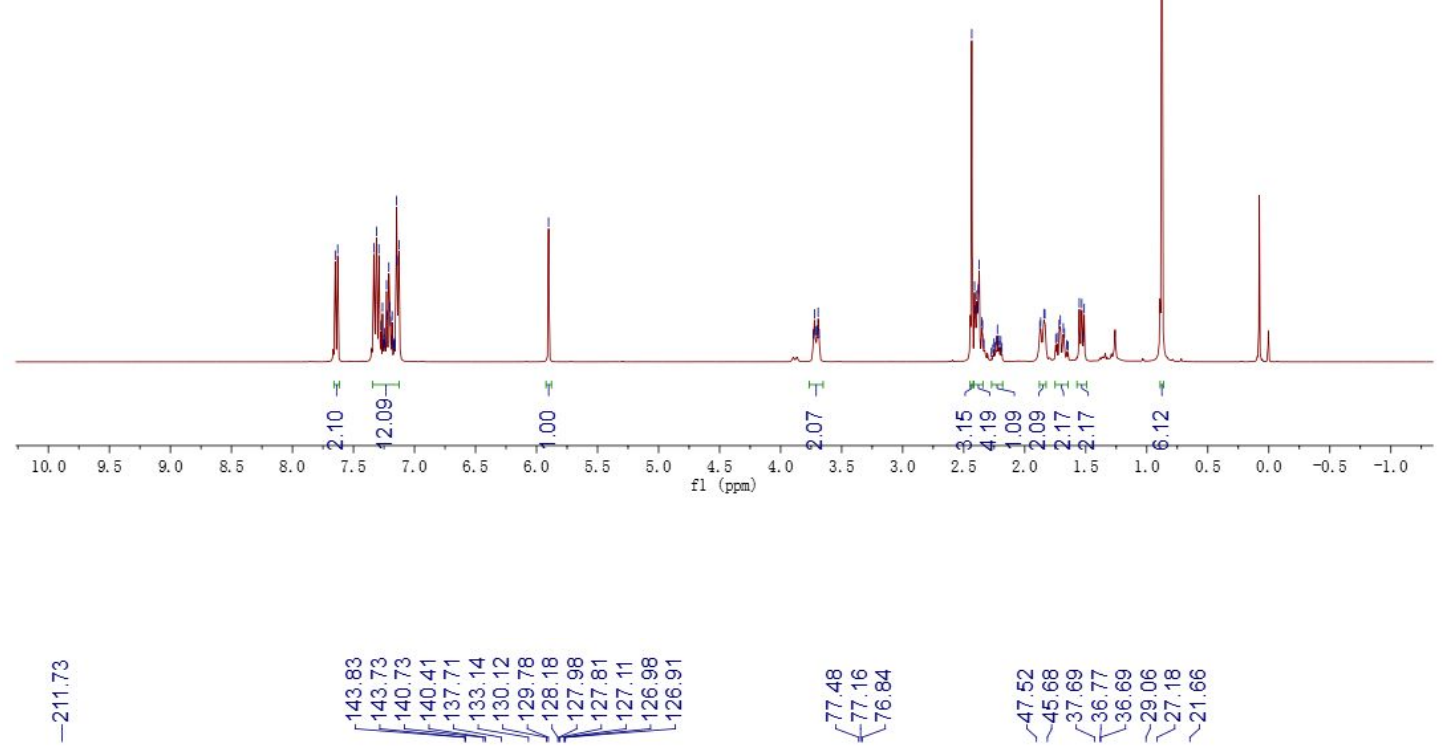

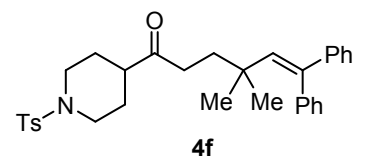

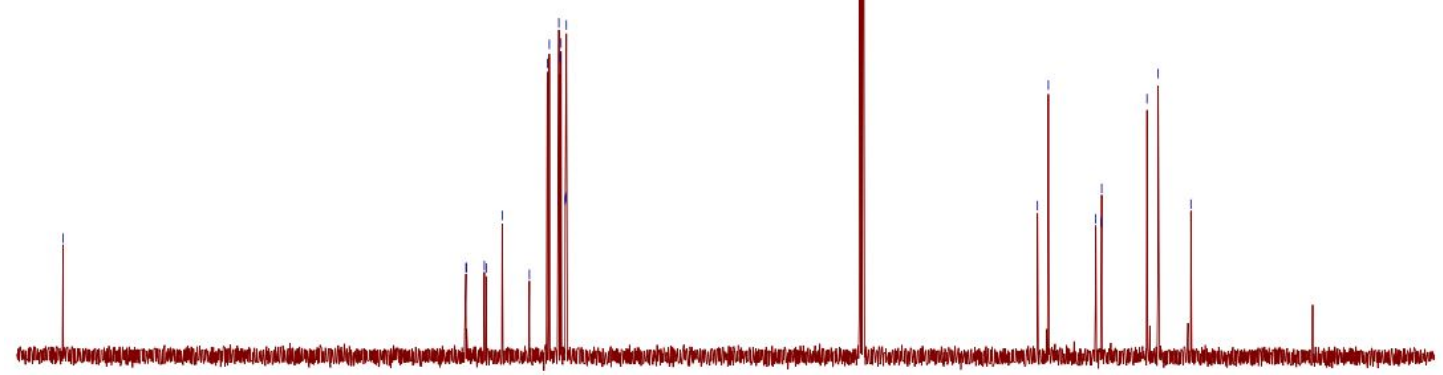

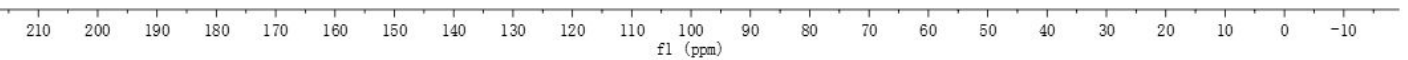


<smiles>CC(=O)CCC1(C=C(c2ccccc2)c2ccccc2)CCCC1</smiles>

$4 \mathrm{~g}$

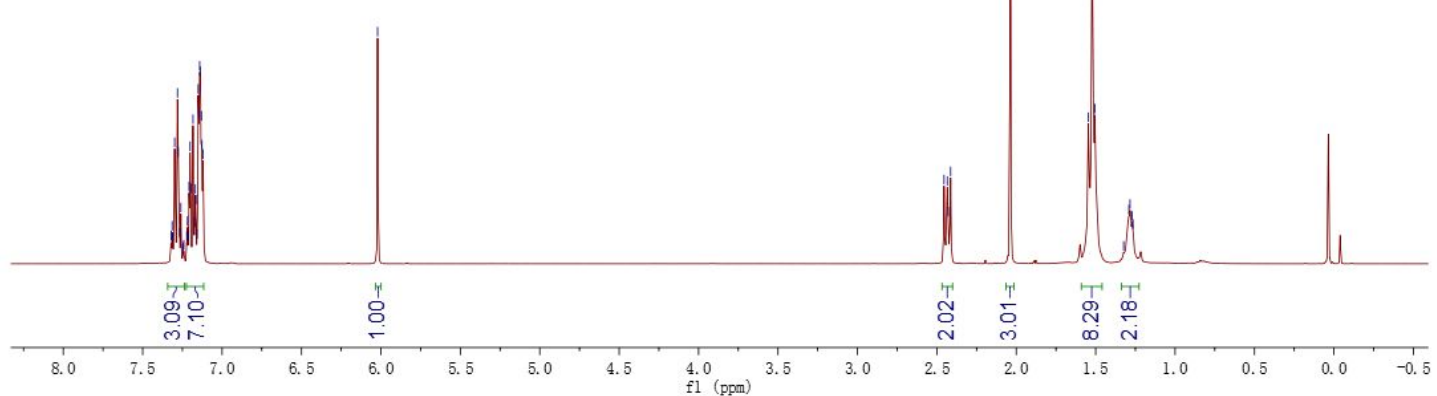

若

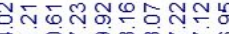

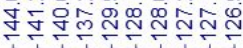

$\stackrel{4}{\infty} \div$

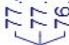

ㄱำ

अव्युल्ल<smiles>CC(=O)CCC1(C=C(c2ccccc2)c2ccccc2)CCCC1</smiles>

$4 \mathrm{~g}$

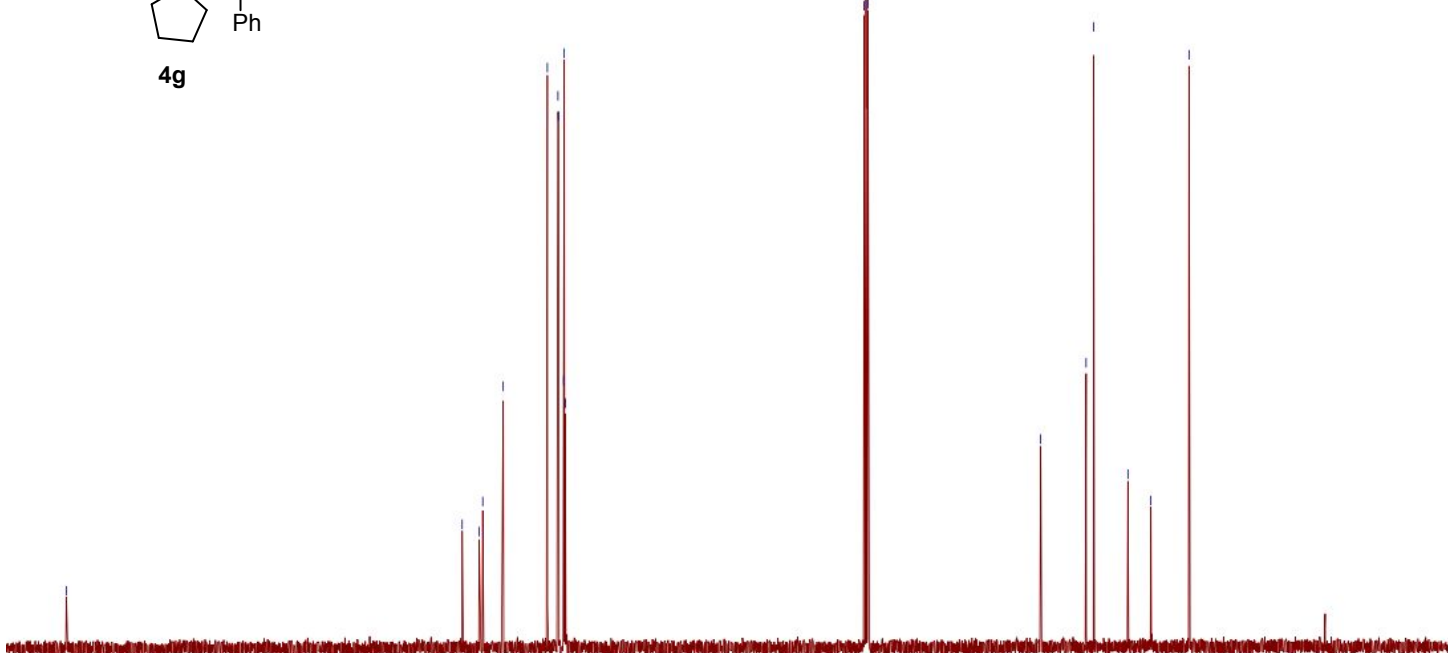

$\begin{array}{lllllllllllll}210 & 200 & 190 & 180 & 170 & 160 & 150 & 140 & 130 & 120 & 110 & 100 & 90\end{array}$
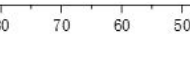

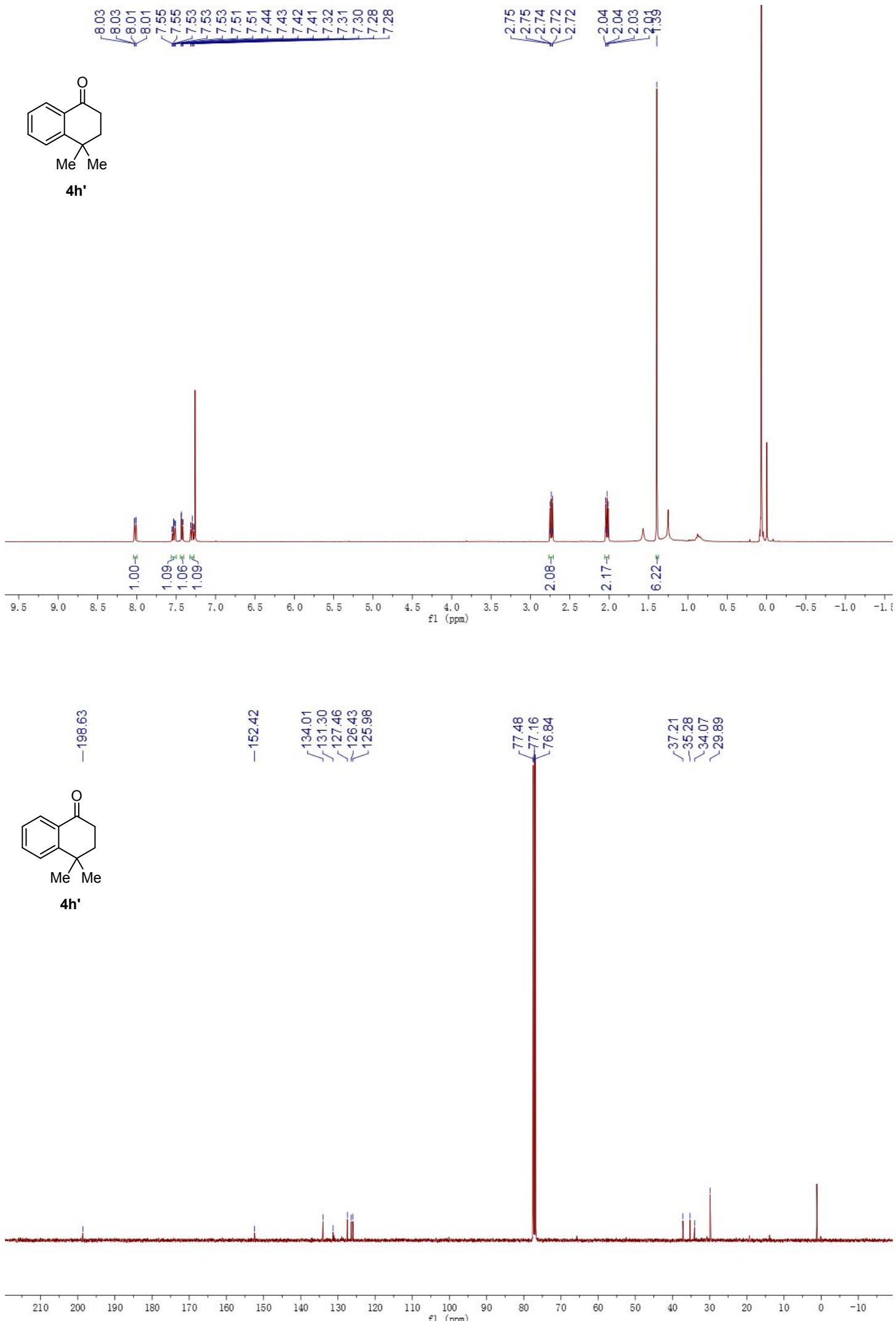


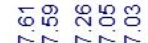

viviv

$\left.\right|_{\pi_{0}^{i}} ^{M e}$

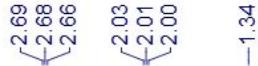
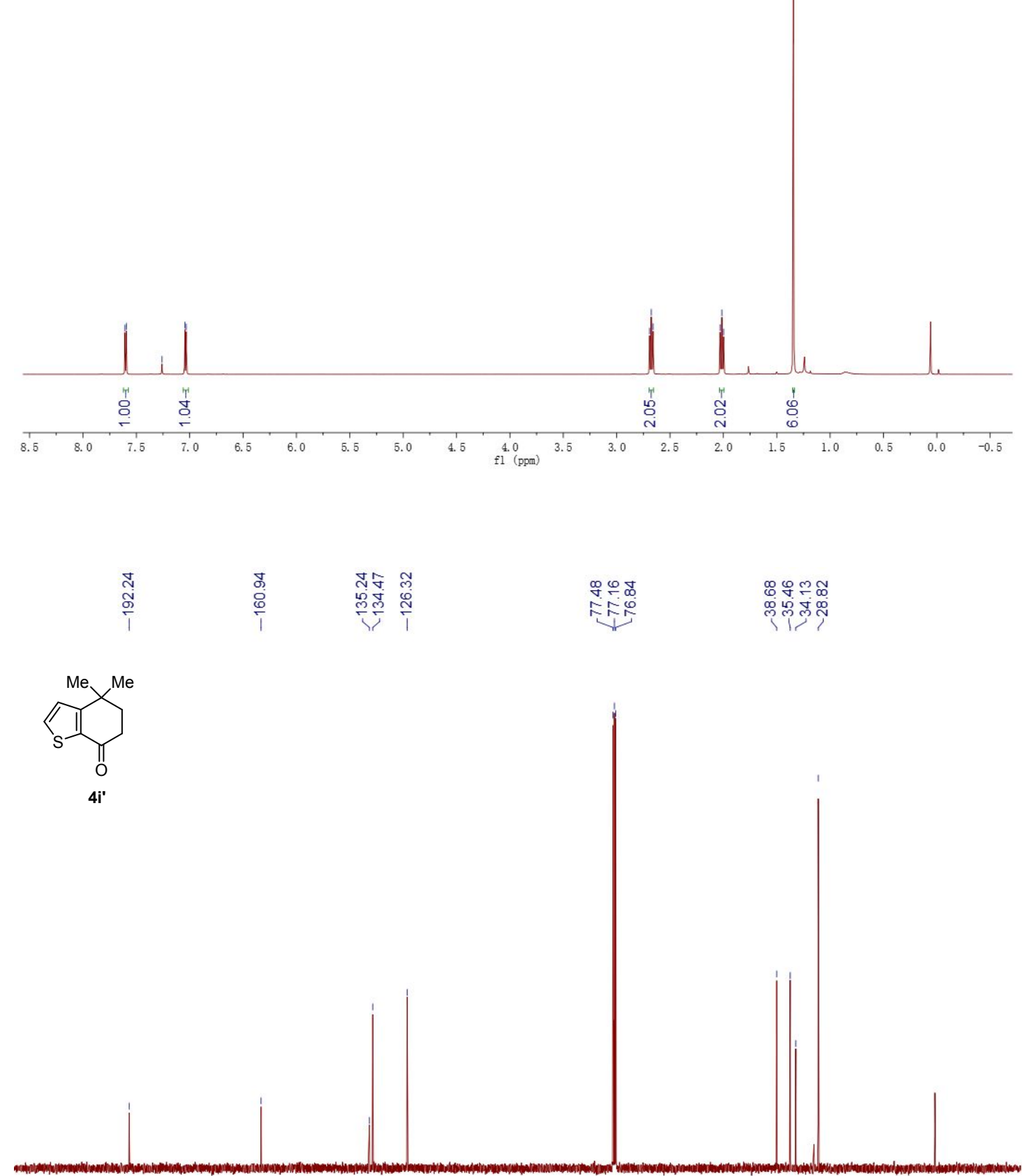

$\begin{array}{lllllllllllllllllllllllllllllllllllll}1 & 210 & 200 & 190 & 180 & 170 & 160 & 150 & 140 & 130 & 120 & 110 & 100 & 90 & 80 & 70 & 60 & 50 & 40 & 30 & 20 & 10 & 0 & -10\end{array}$ 


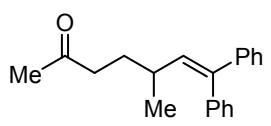

$4 \mathrm{j}$

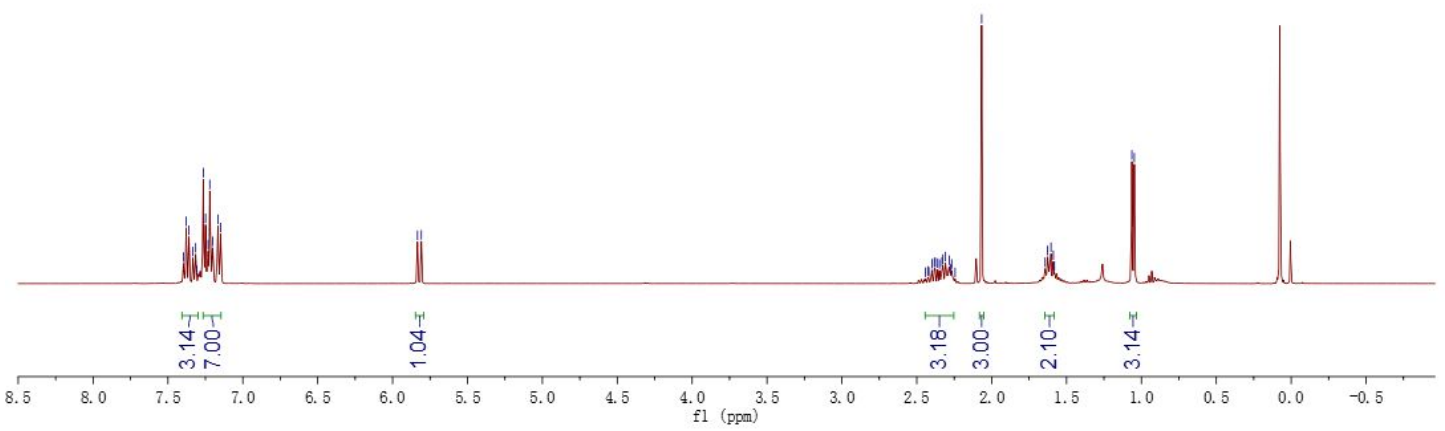<smiles>CC=CC(C=C(c1ccccc1)c1ccccc1)CCC(C)=O</smiles>

요 윰ำ

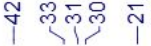
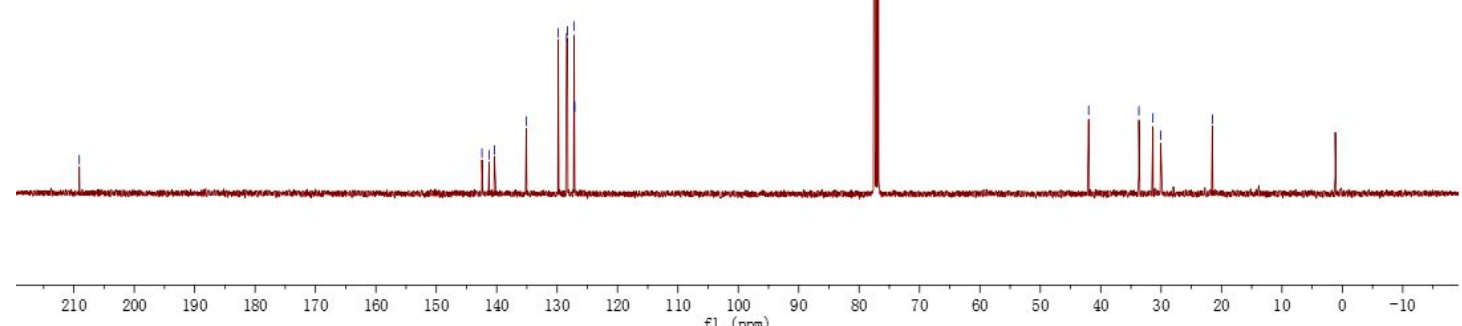


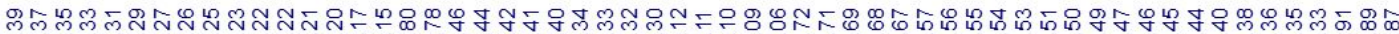

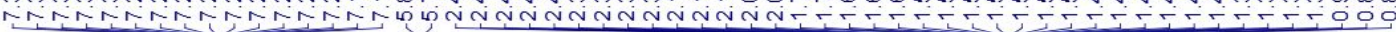<smiles>CCC(C=C(c1ccccc1)c1ccccc1)CCC(C)=O</smiles>

$4 \mathbf{k}$

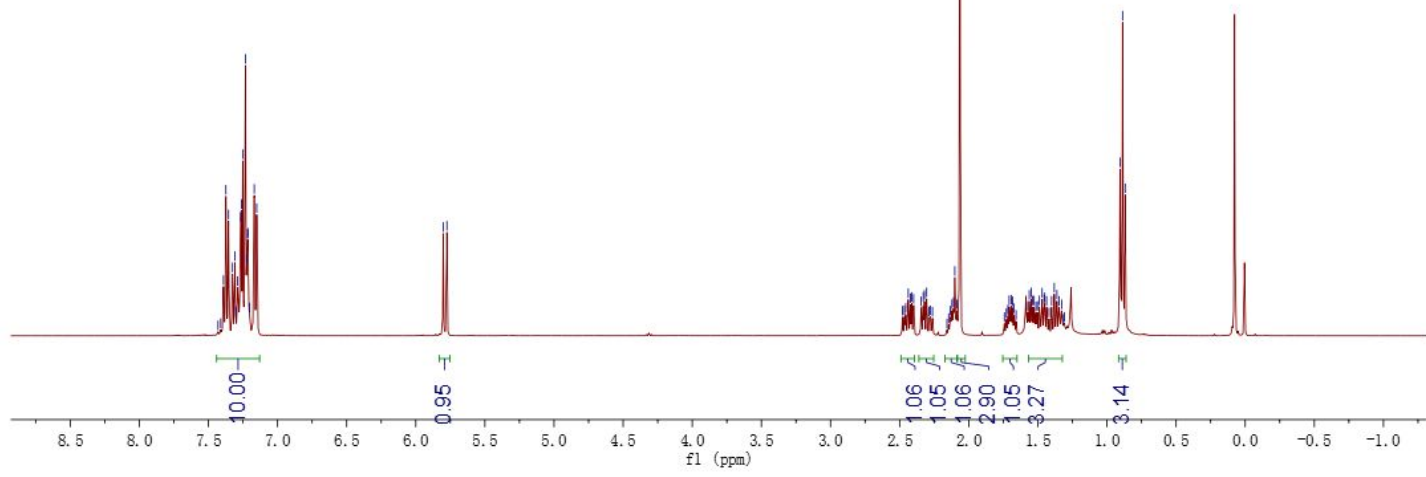

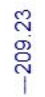

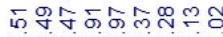

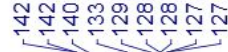

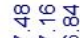
证

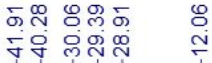

$\underbrace{N_{4 k}^{O}}_{M e}=\overbrace{P h}^{P h}$

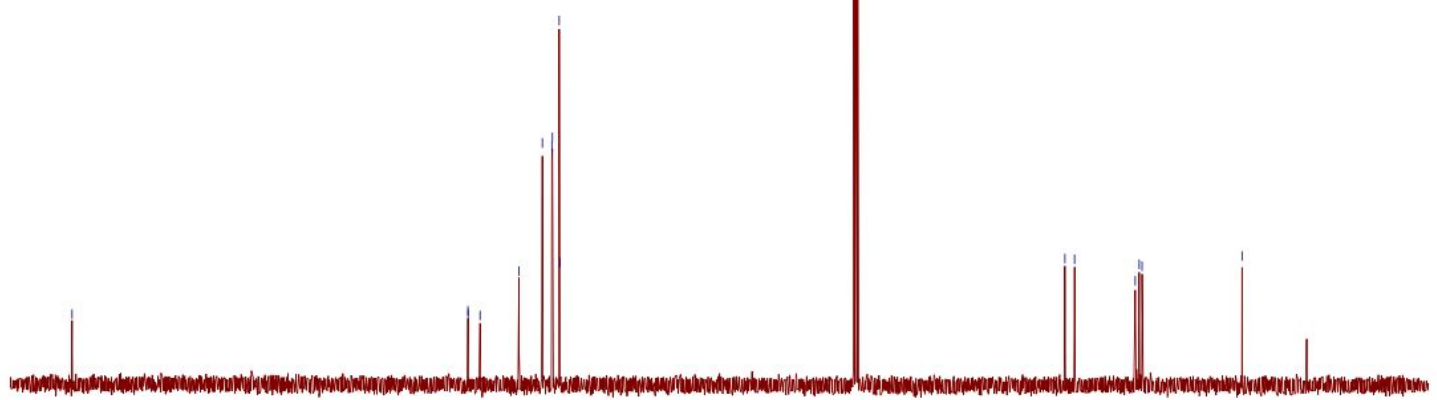

$\begin{array}{llllllllllllllllllllllll}1 & 10 & 200 & 190 & 180 & 170 & 160 & 150 & 140 & 130 & 120 & 110 & 100 & 90 & 80 & 70 & 60 & 50 & 40 & 30 & 20 & 10 & 0 & -10\end{array}$ 

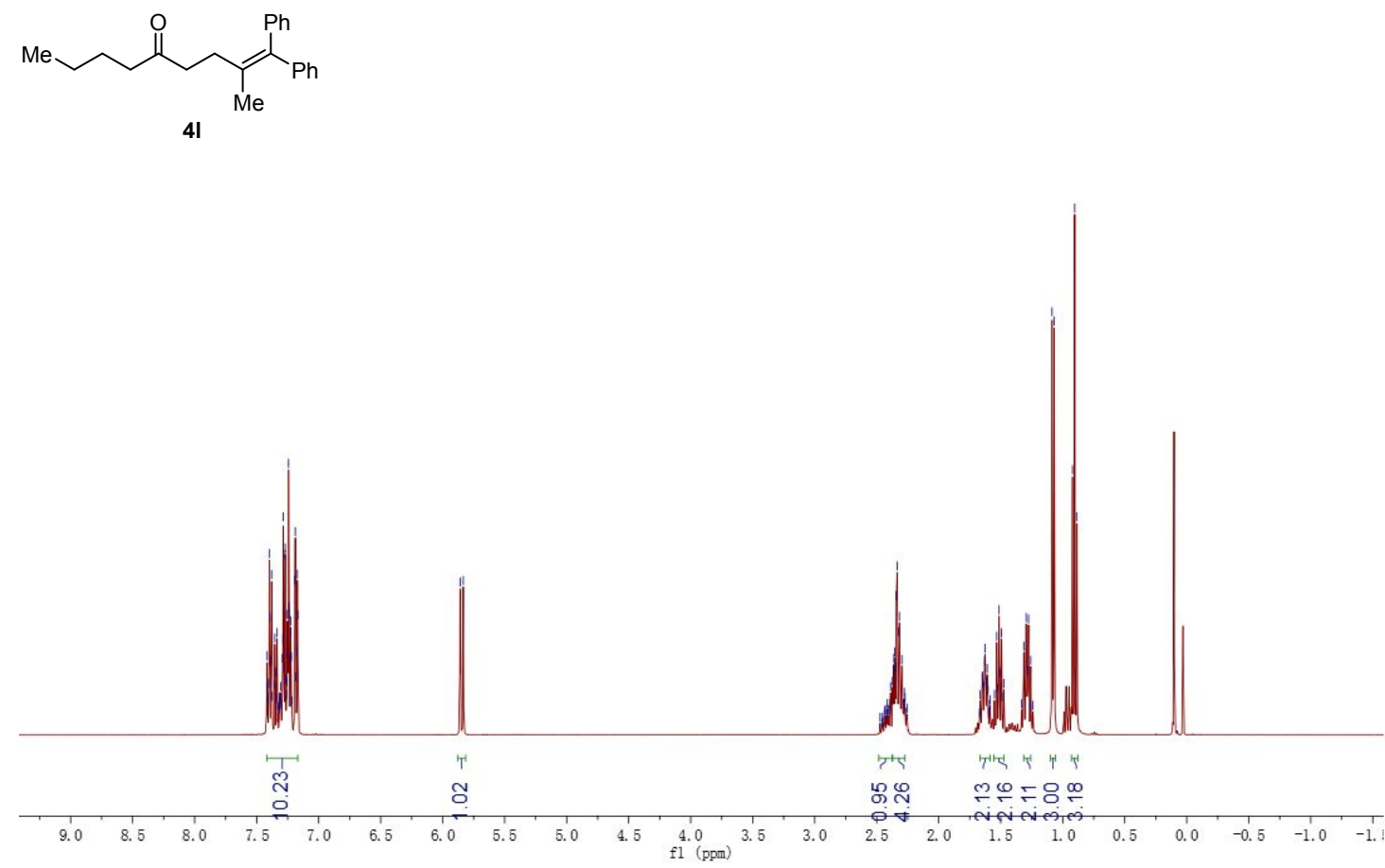

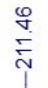

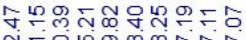

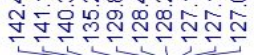

$\stackrel{\sim}{\infty} \stackrel{\infty}{\infty} \div$

证息

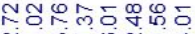

iาd

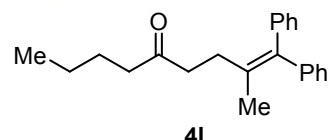

4!

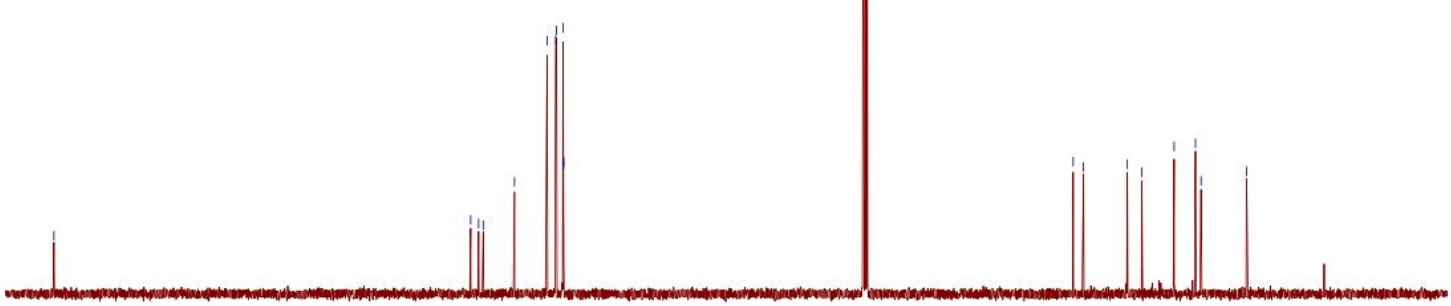

$\begin{array}{llllllllllllll}210 & 200 & 190 & 180 & 170 & 160 & 150 & 140 & 130 & 120 & 110 & 100 & 90\end{array}$ 


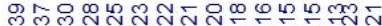

vininivitiviog

Ph

$4 \mathrm{~m}$

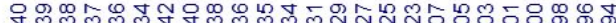

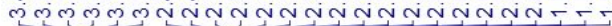

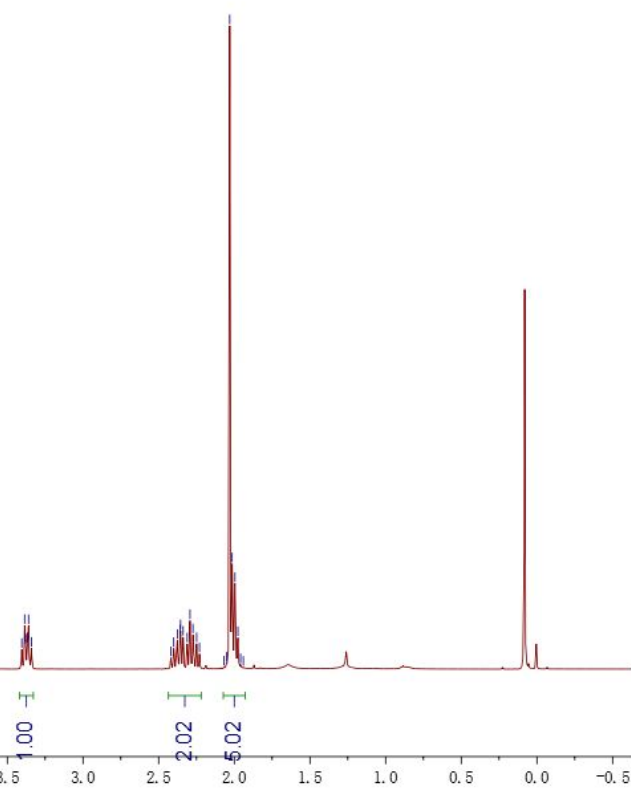

ง ำกำ

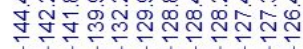

(l)

$4 \mathrm{~m}$ $\stackrel{\infty}{\infty} \stackrel{\infty}{\infty} \underset{\infty}{\infty}$

证

गं लंख

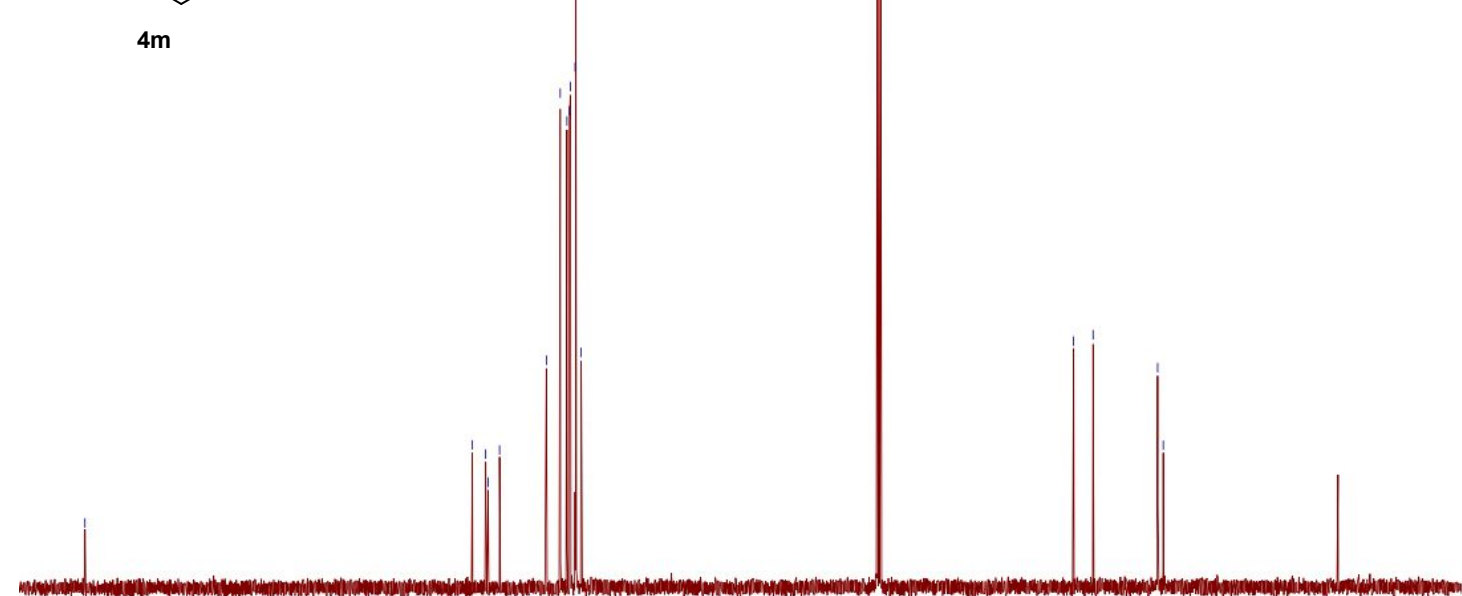

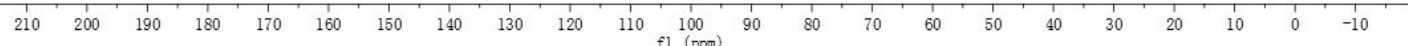


<smiles>COc1ccc(/C(=C/C(=O)CCC(=O)c2ccccc2)c2ccccc2)cc1</smiles>
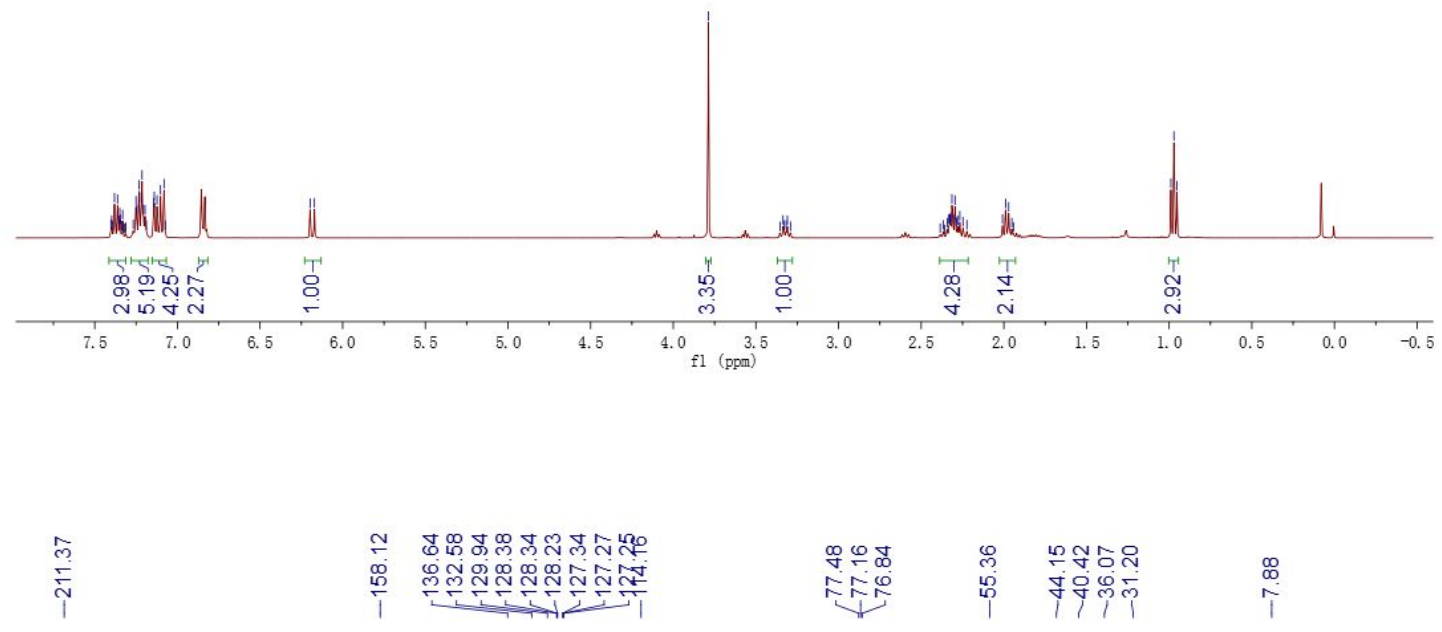<smiles>CCC(=O)CCC(/C=C(\c1ccccc1)c1ccc(OC)cc1)c1ccccc1</smiles>

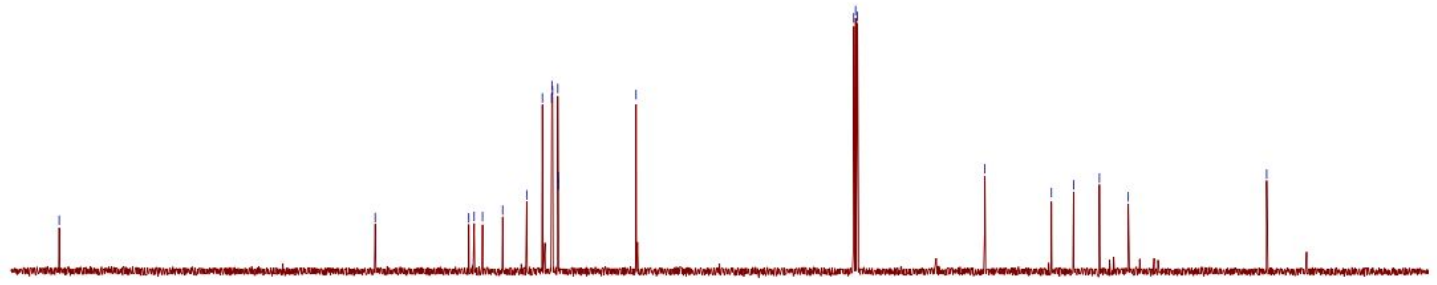

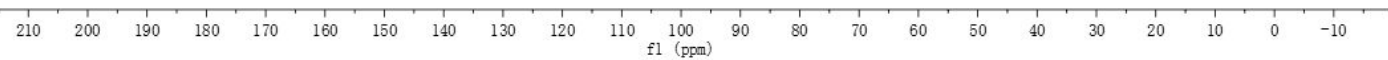




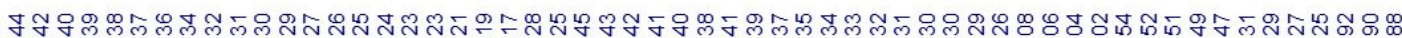
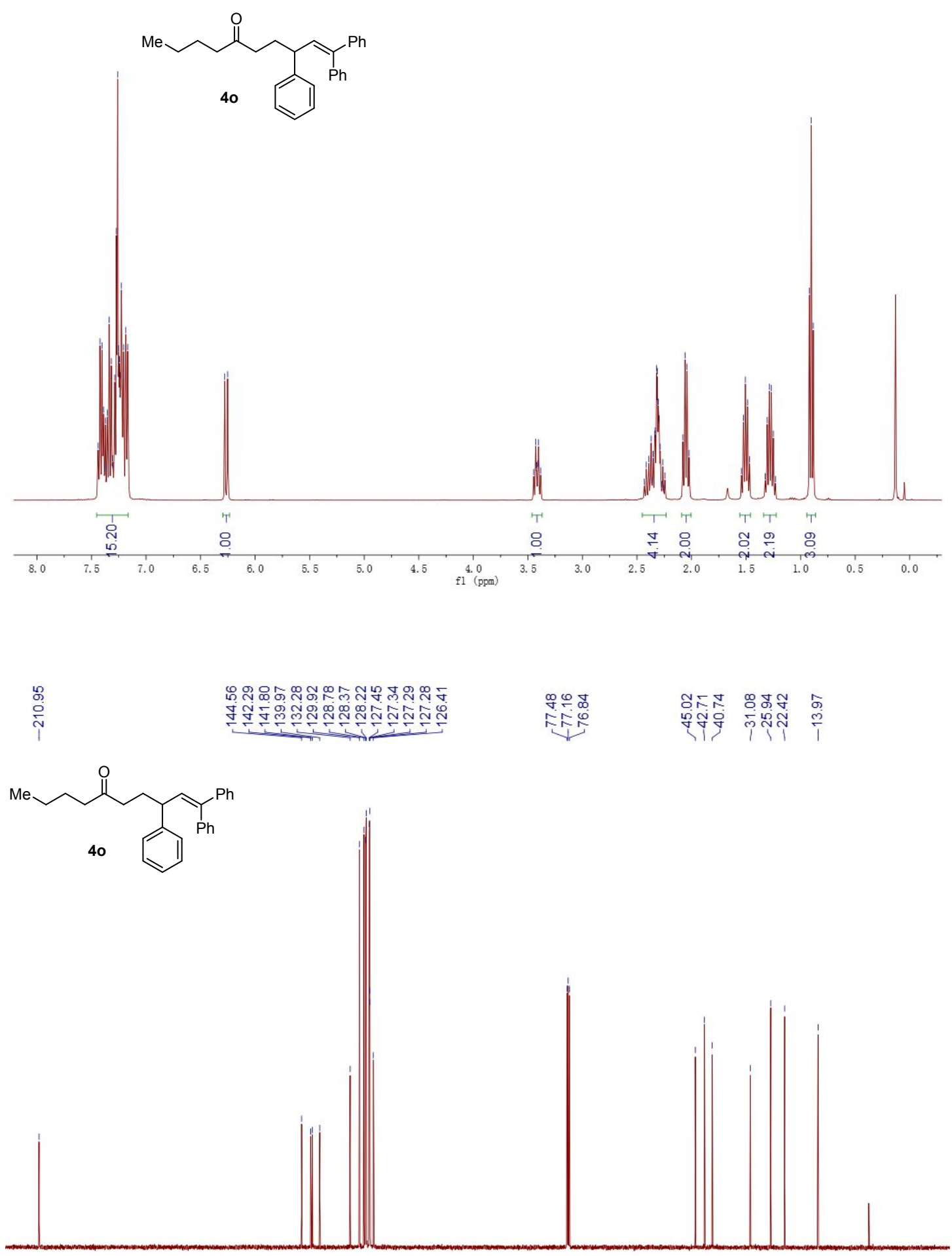

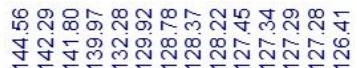

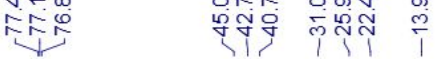

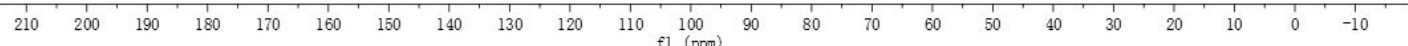




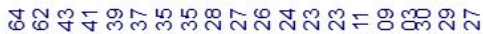

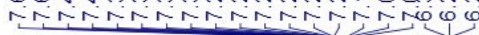

요료

$\overbrace{4 p}^{P h}$

mind în

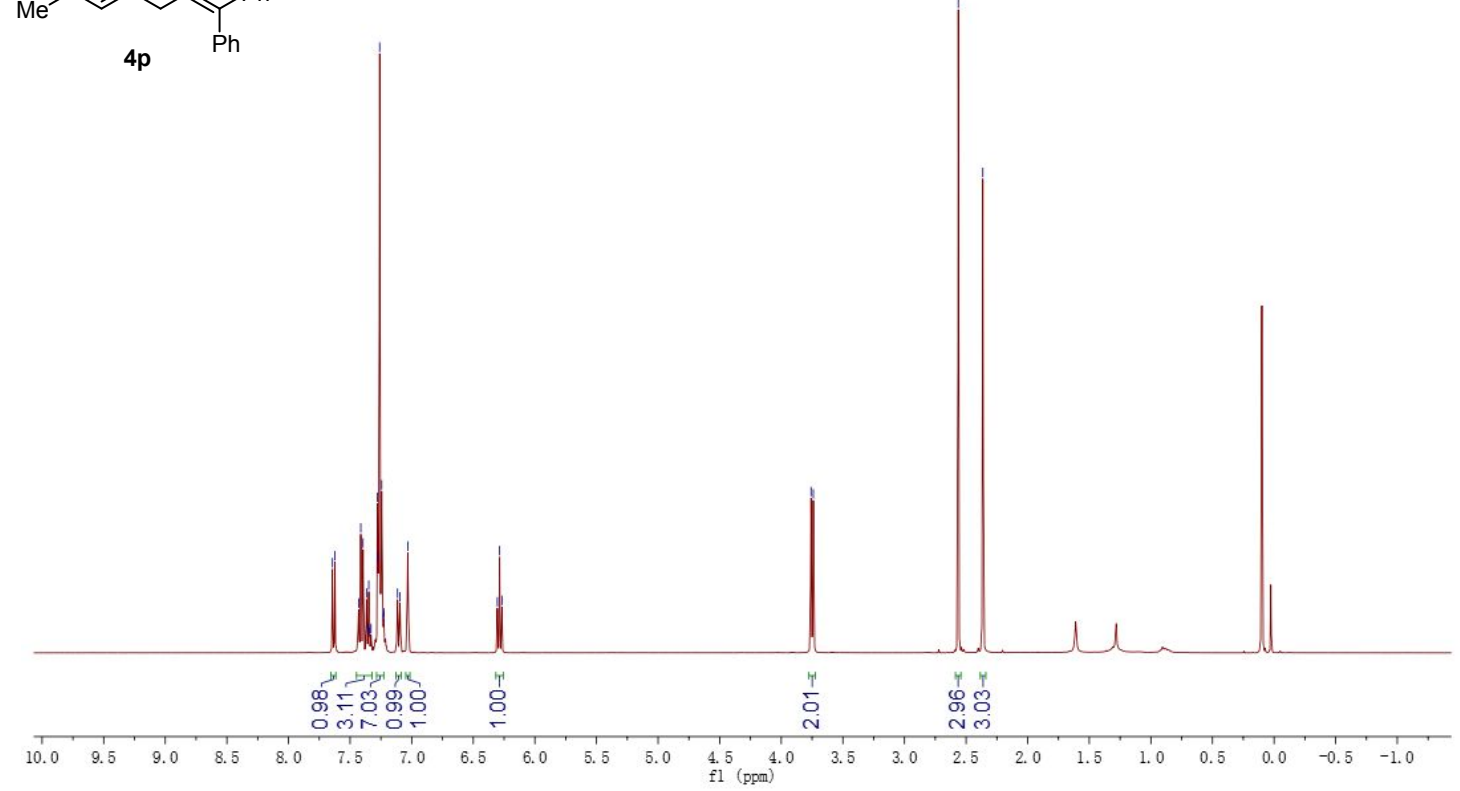

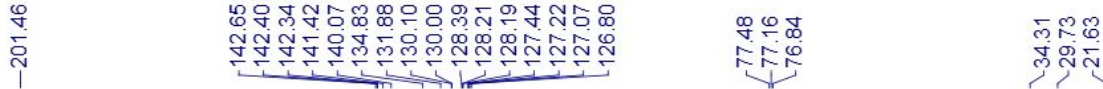<smiles>CC(=O)c1ccc(C)cc1CC=C(c1ccccc1)c1ccccc1</smiles>

$4 p$
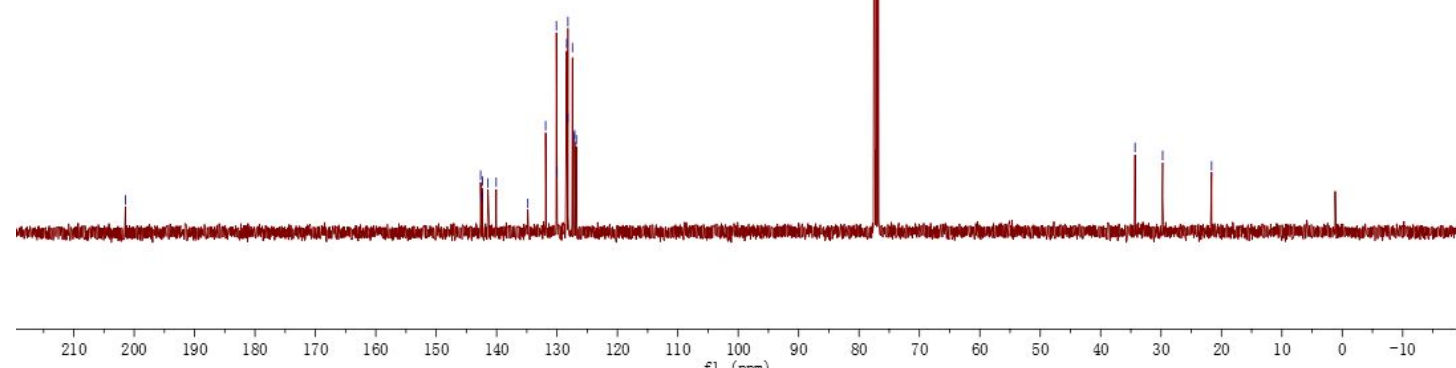


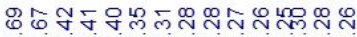

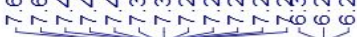

岗<smiles>O=C(O)c1ccccc1CC=C(c1ccccc1)c1ccccc1</smiles>

$4 q$

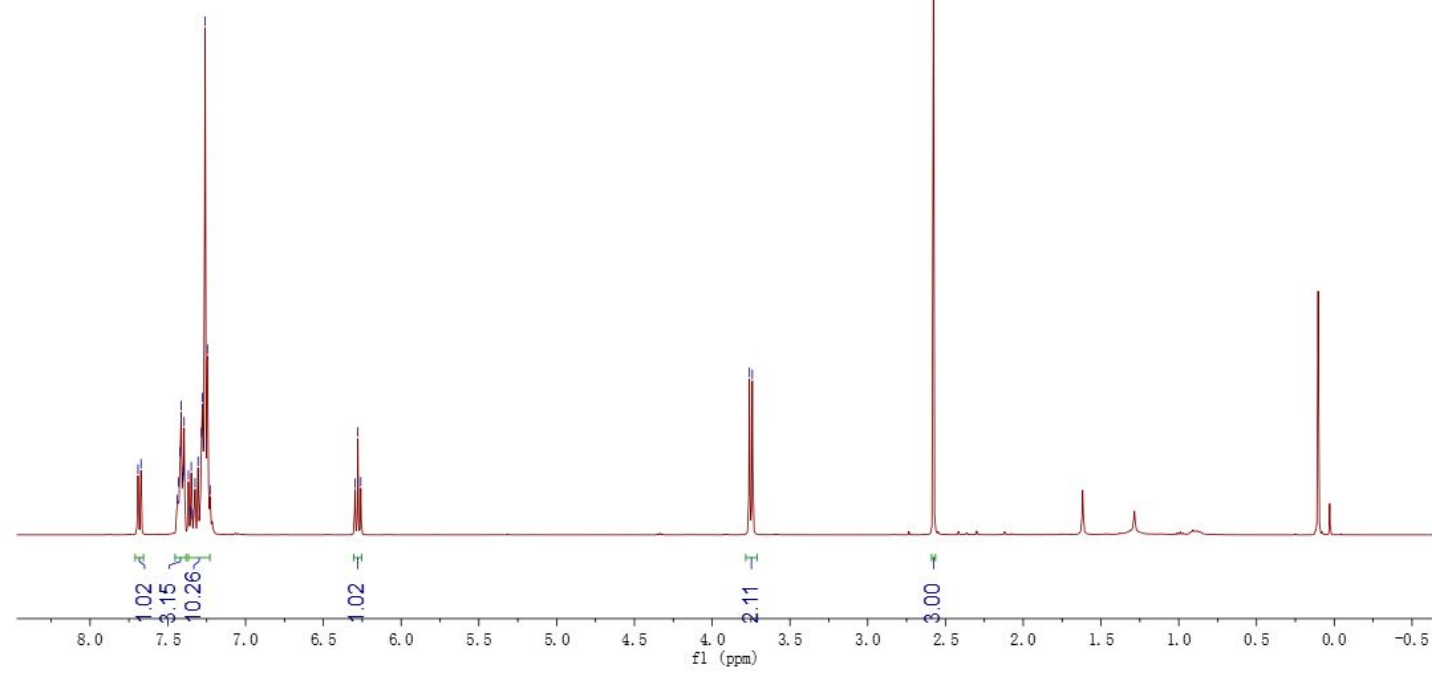

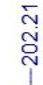

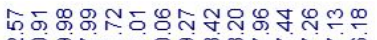

ํํำ

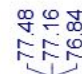

mֻ<smiles>COC(=O)c1ccccc1CC=C(c1ccccc1)c1ccccc1</smiles>

$4 q$

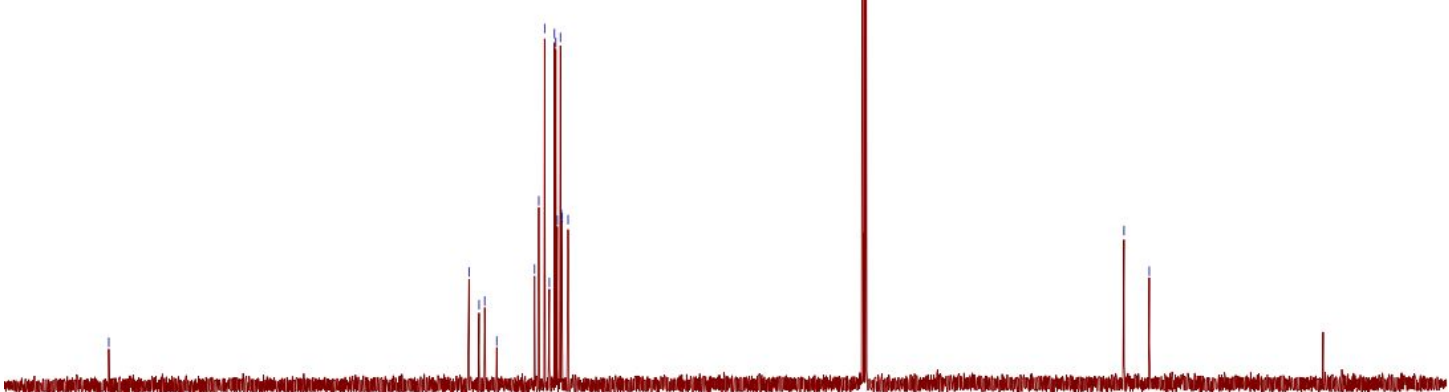

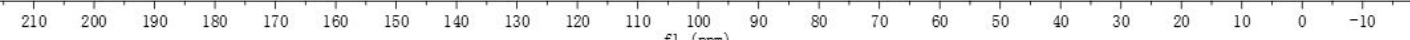



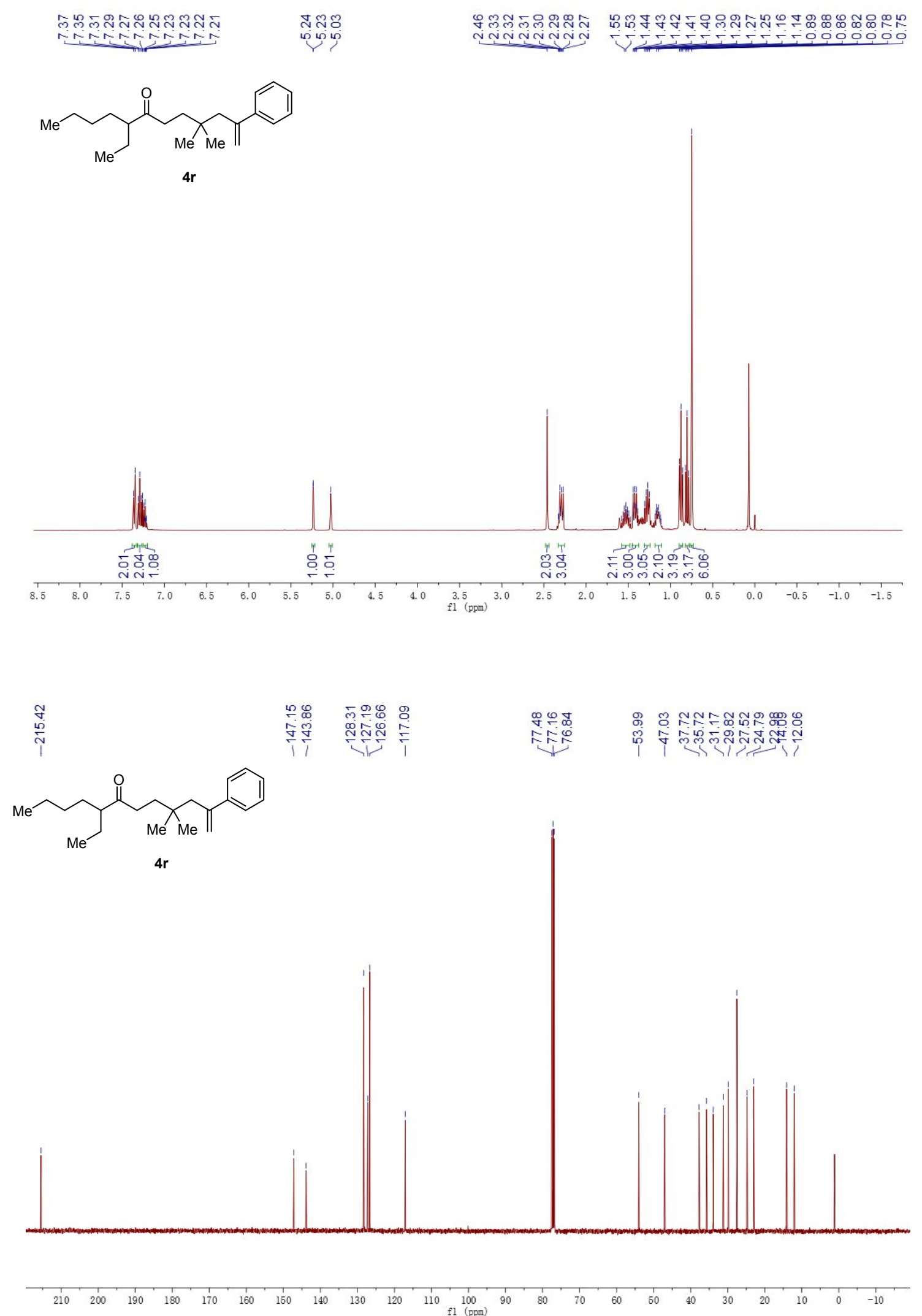

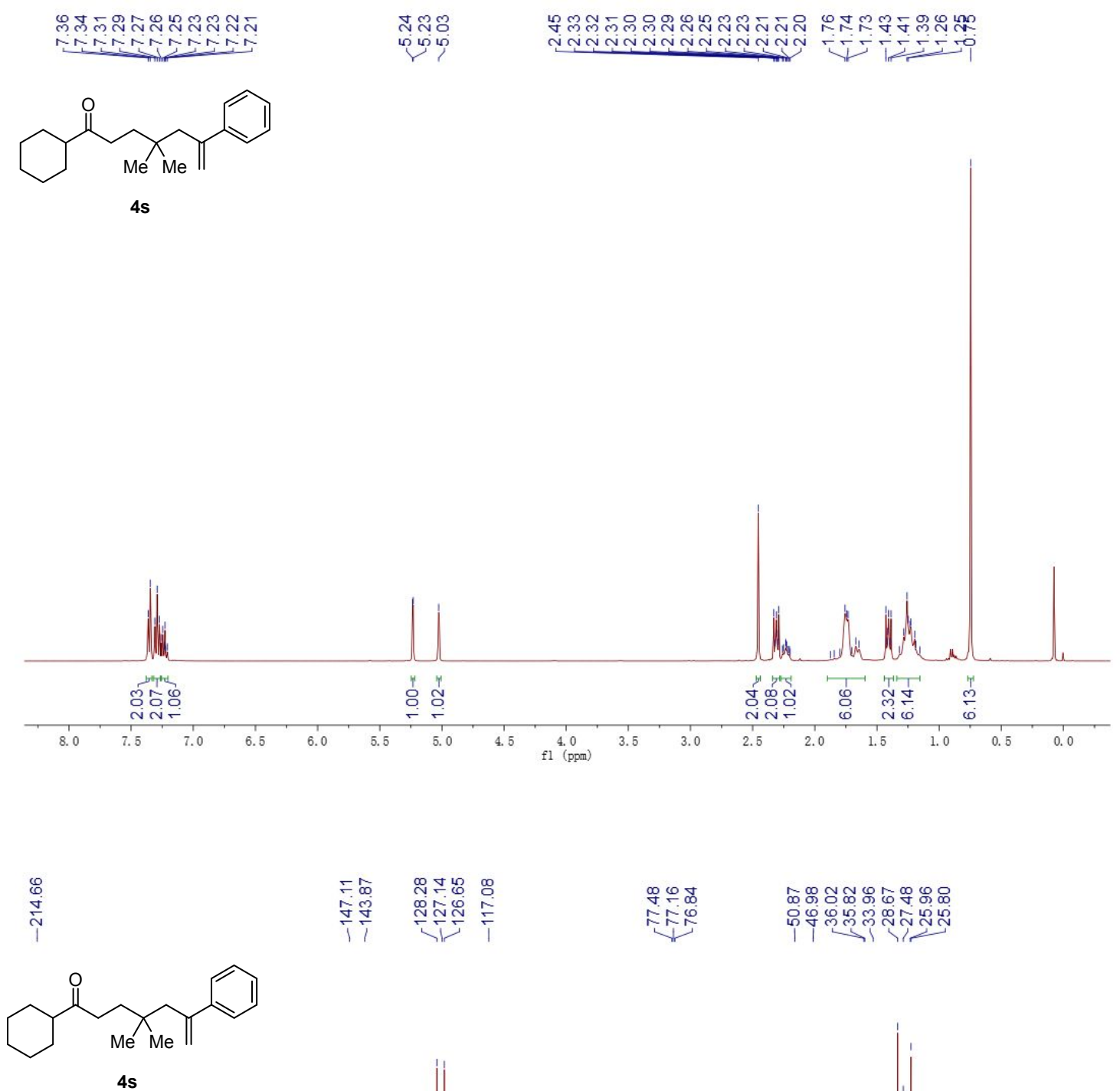

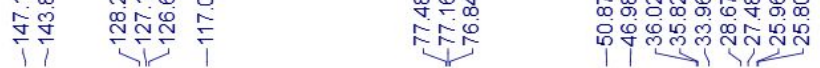

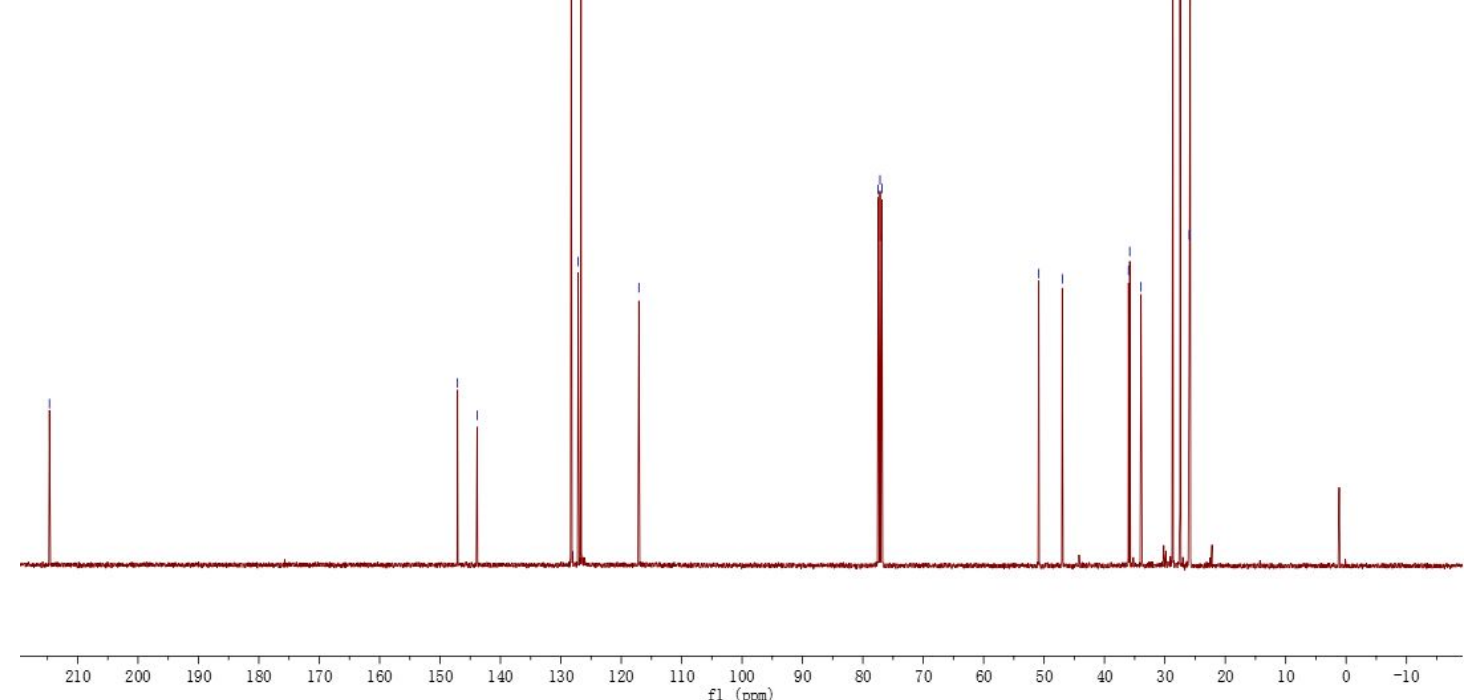



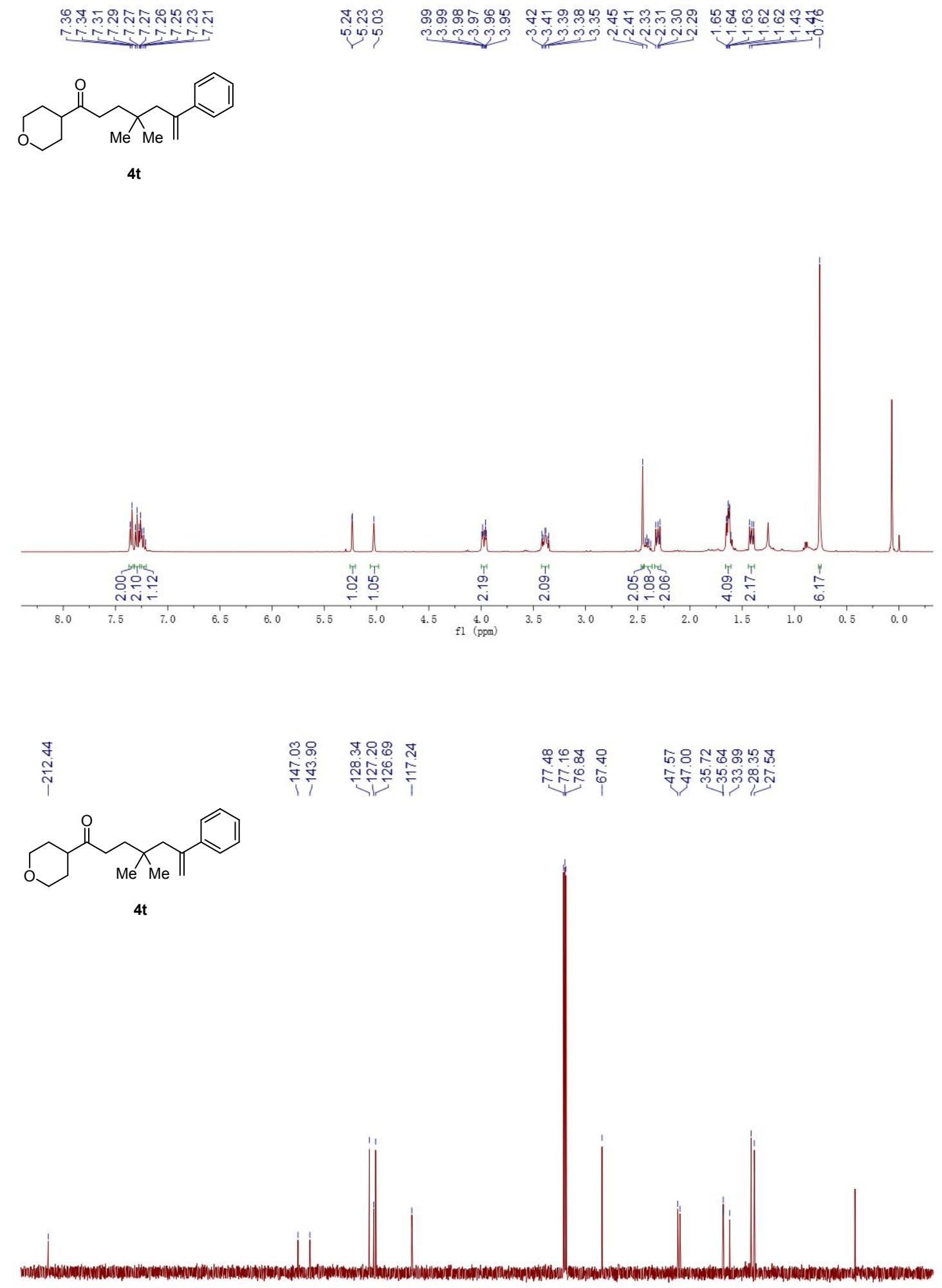

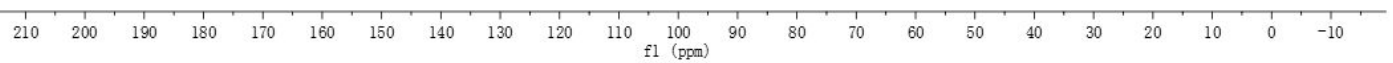



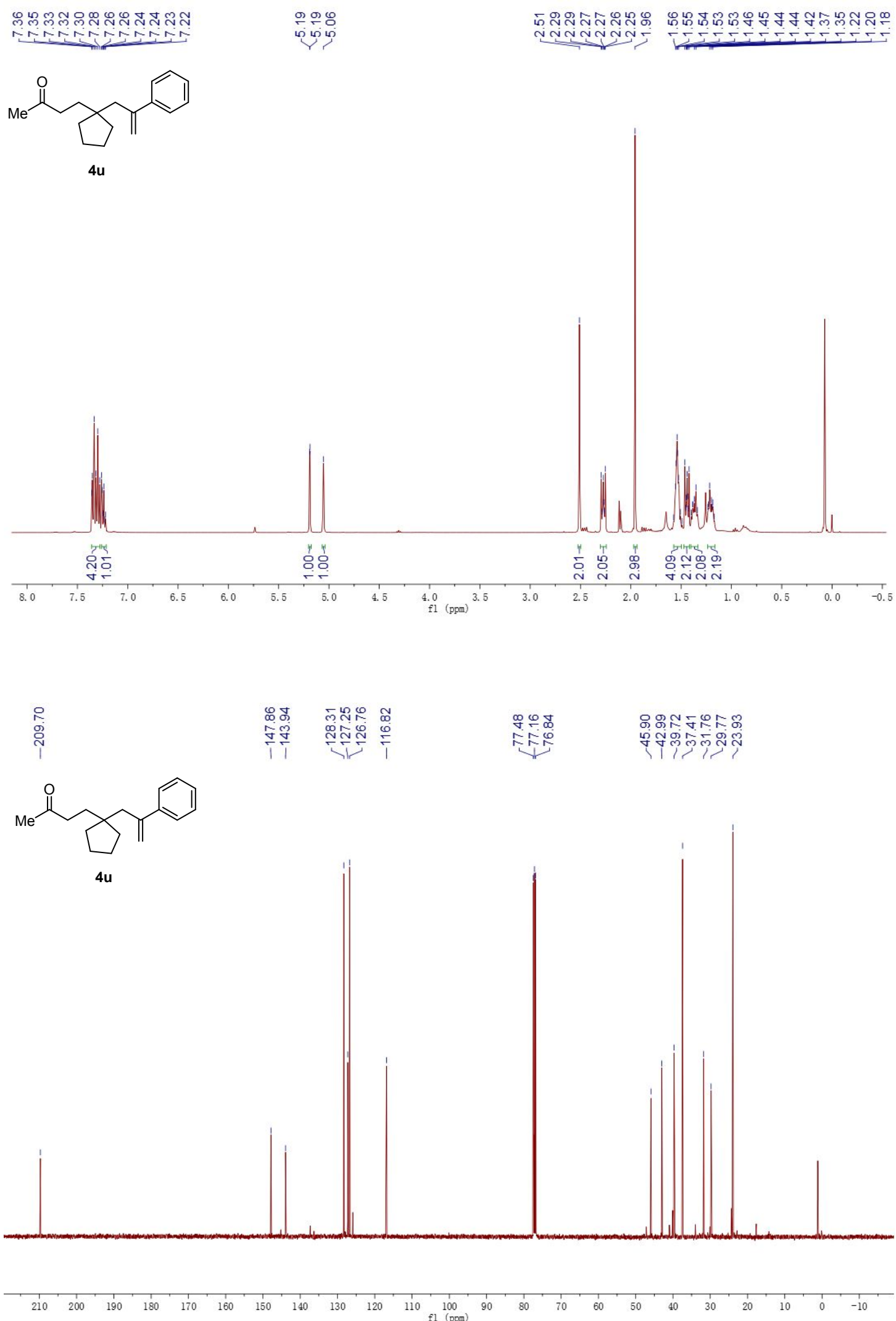
${ }^{1} \mathrm{H}$ NMR and ${ }^{13} \mathrm{C}\left\{{ }^{1} \mathrm{H}\right\}$ NMR Spectra of Products 5a and 6a
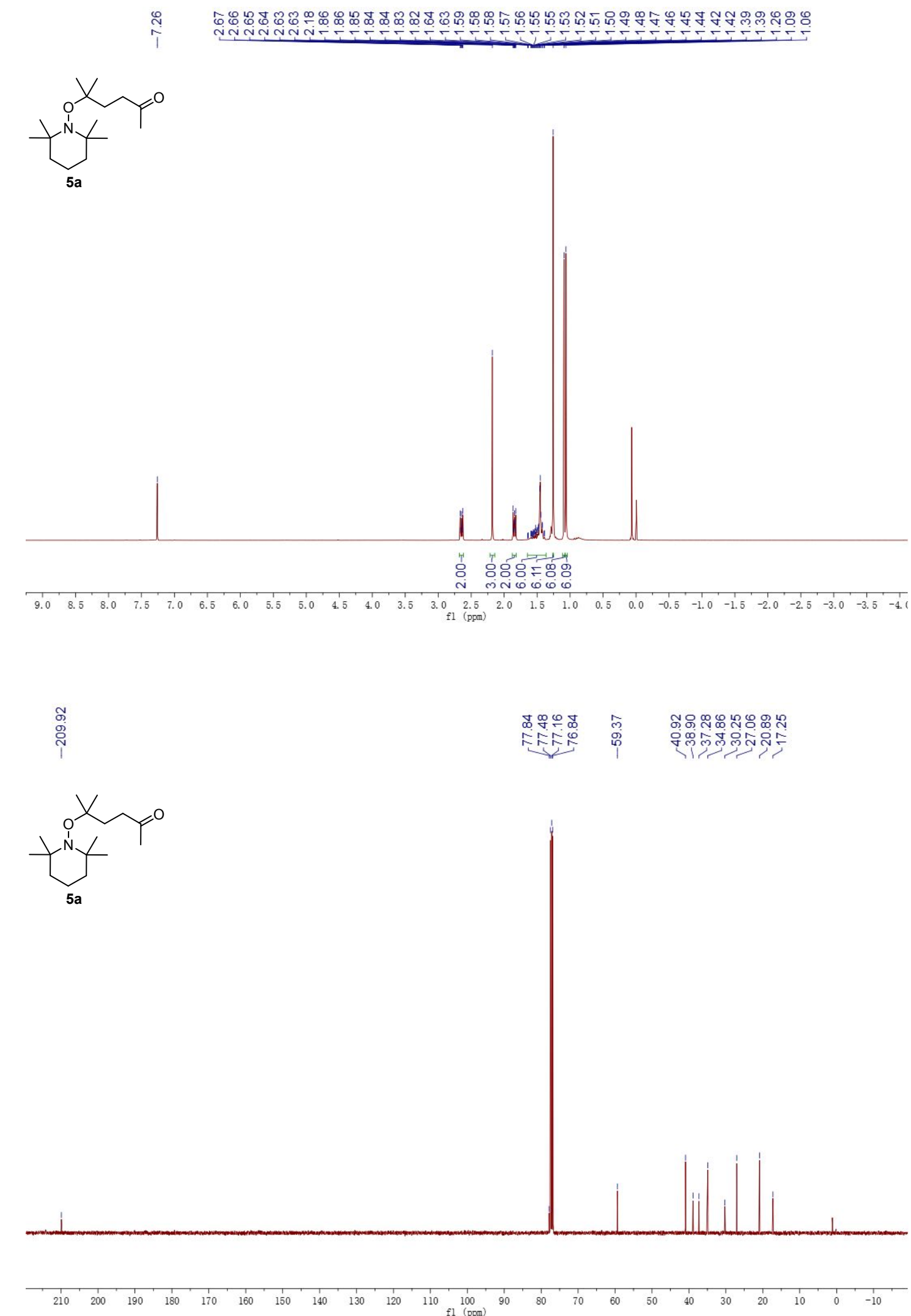
<smiles>CC(=O)CCC(C)(C)CC1=CCCc2ccccc21</smiles>
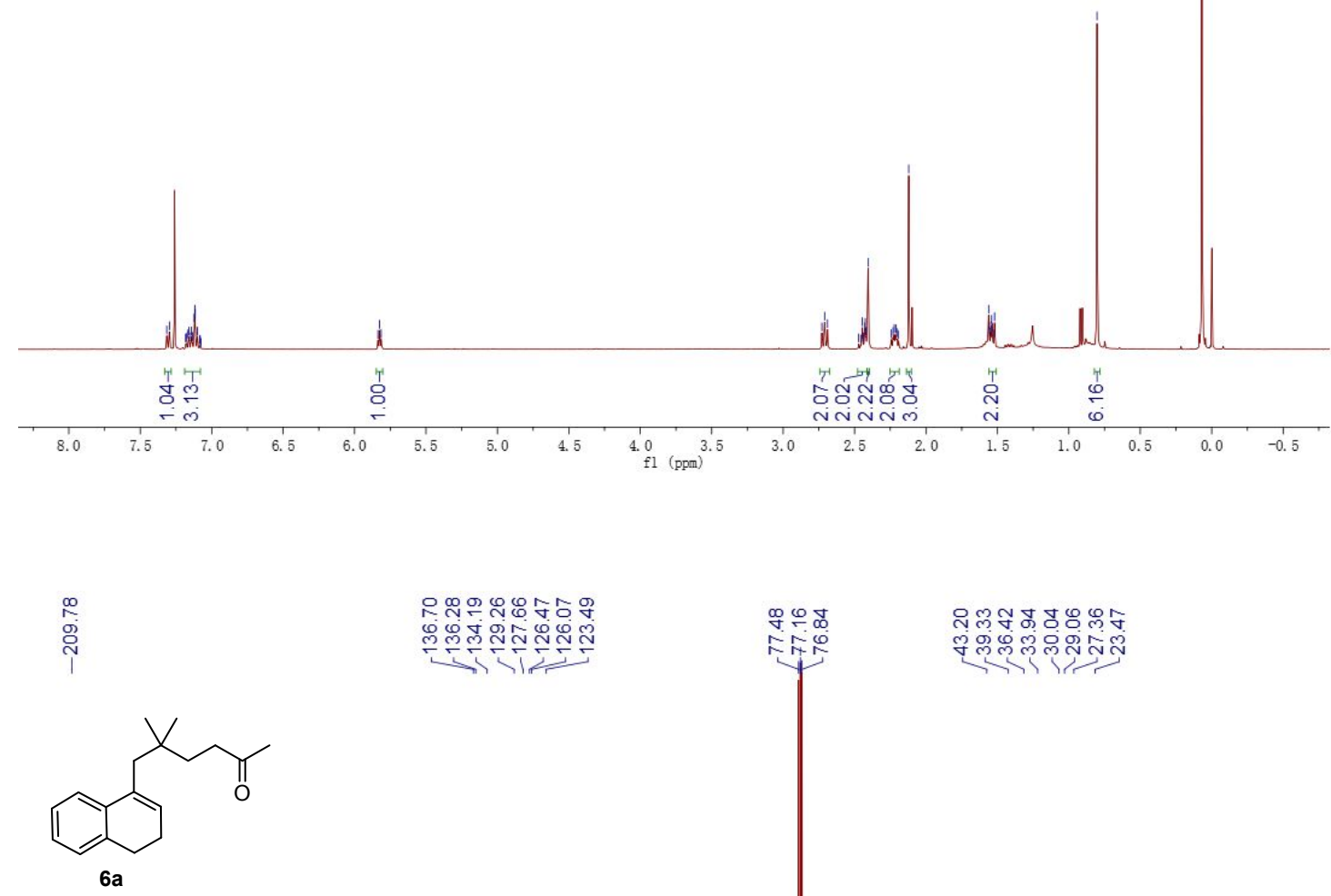

II illi
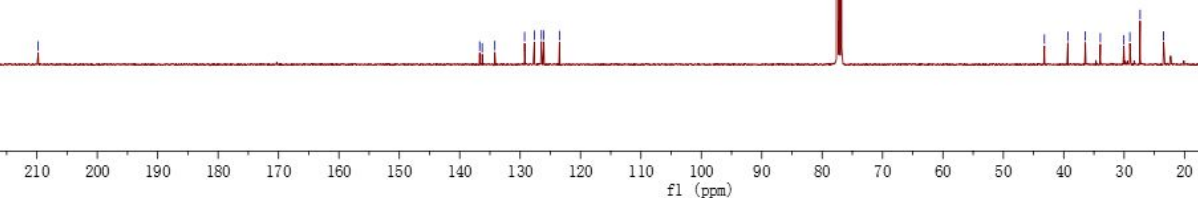